Nevada

Environmental

Restoration

Project

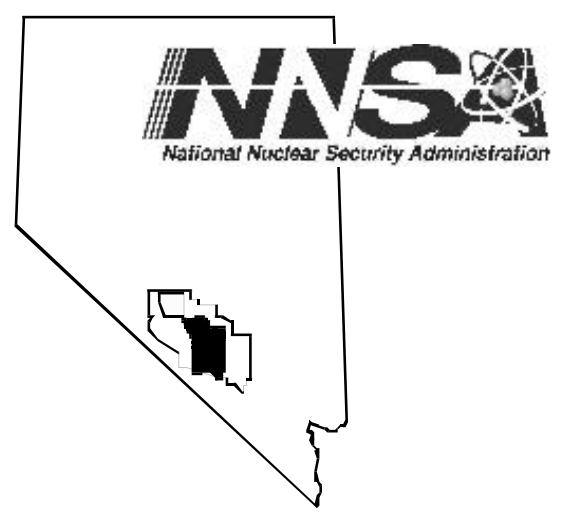

\title{
Completion Report for Well ER-7-1
}

November 2004

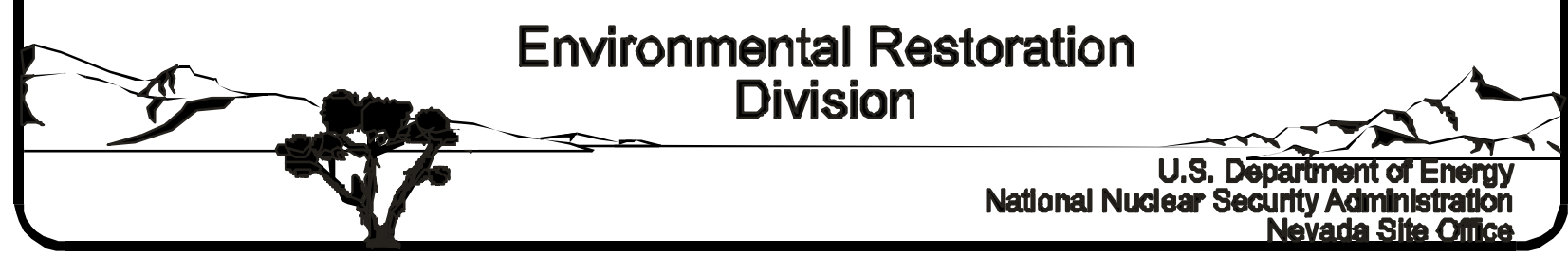




\section{DISCLAIMER STATEMENT}

Reference herein to any specific commercial product, process, or service by trade name, trademark, manufacturer, or otherwise, does not necessarily constitute or imply its endorsement, recommendation, or favoring by the U.S. Government or any agency thereof or its contractors or subcontractors.

\section{AVAILABILITY STATEMENT}

Available to the public, in paper, from-

U.S. Department of Commerce

National Technical Information Service

5285 Port Royal Road

Springfield, VA, 22161-0002

Telephone: 800.553 .6847

Fax: 703.605.6900

E-mail: orders@ntis.gov

Online ordering: http://www.ntis.gov/ordering.htm

Available electronically at http://www.osti.gov/bridge

Available for a processing fee to U.S. Department of Energy and its contractors, in paper, from-

U.S. Department of Energy

Office of Scientific and Technical Information

P.O. Box 62

Oak Ridge, TN 37831-0062

Telephone: 865.576 .8401

Fax: 865.576.5728

E-mail: reports@adonis.osti.gov 


\title{
Completion Report for Well ER-7-1
}

\author{
Prepared for: \\ U.S. Department of Energy \\ National Nuclear Security Administration \\ Nevada Site Office \\ Las Vegas, Nevada
}

Prepared by:

Bechtel Nevada

Geotechnical Sciences

Las Vegas, NV

November 2004 
This page intentionally left blank. 
DOE/NV/11718--865

\section{COMPLETION REPORT FOR WELL ER-7-1}

Approved by: Wheknah R-uilin

William R. Wilborn, Acting Project Manager,

Underground Test Area Project
Date: $12 / 15 / 04$

Date: $12 / 15 / 04$

Approved by: $\frac{\text { Rolent Pn. Bungerler }}{\text { Robert M. Bangerter, Acting Director, }}$ Environmental Restoration Division 
This page intentionally left blank. 


\title{
Completion Report for Well ER-7-1 \\ DOE/NV/11718--865
}

\begin{abstract}
Well ER-7-1 was drilled for the U.S. Department of Energy's National Nuclear Security Administration Nevada Site Office in support of the Nevada Environmental Restoration Project at the Nevada Test Site, Nye County, Nevada. This well was drilled in January and February 2003, as part of a hydrogeologic investigation program in Yucca Flat. A 47.0-centimeter surface hole was drilled and cased off to a depth of 541.0 meters below the surface. The hole diameter was then decreased to 31.8 centimeters for drilling to a total depth of 762.0 meters.
\end{abstract}

One completion string with one slotted interval was installed in the well, open to the lower carbonate aquifer. A preliminary composite static water level was measured at the depth of 565.1 meters on February 7, 2003, before installation of the completion string. Well ER-7-1 was drilled 91.4 meters deeper than planned because the borehole did not encounter significant groundwater at the original planned total depth of 670.6 meters.

Detailed lithologic descriptions with stratigraphic assignments are included in this report. These are based on composite drill cuttings collected every 3 meters, and 62 sidewall samples taken at various depths below 85.3 meters, supplemented by geophysical log data. Detailed petrographic, chemical, and mineralogical studies were conducted on 22 samples of cuttings. The well was collared in Quaternary surficial deposits and penetrated a thick section of Tertiary-age volcanic deposits before terminating in carbonate rocks of Paleozoic-age. 
This page intentionally left blank. 


\section{Table of Contents}

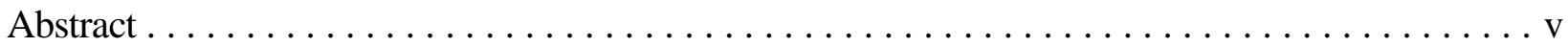

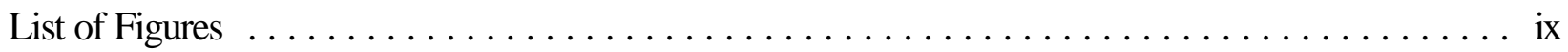

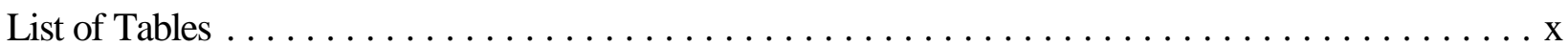

List of Acronyms and Abbreviations $\ldots \ldots \ldots \ldots \ldots \ldots \ldots \ldots \ldots \ldots \ldots \ldots \ldots \ldots \ldots \ldots \ldots \ldots$

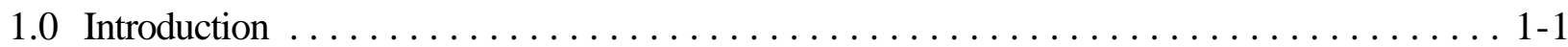

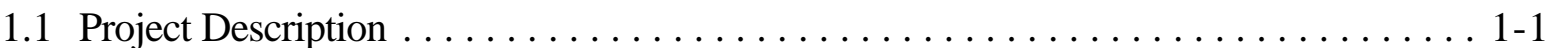

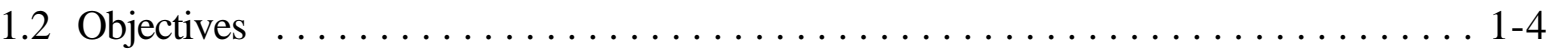

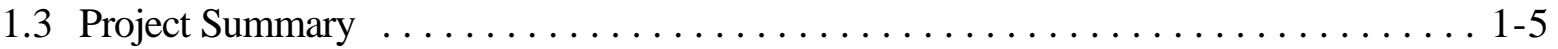

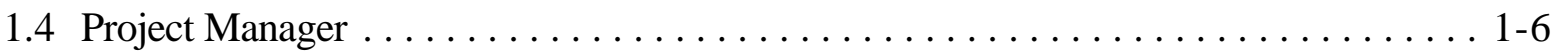

2.0 Drilling Summary $\ldots \ldots \ldots \ldots \ldots \ldots \ldots \ldots \ldots \ldots \ldots \ldots \ldots \ldots \ldots \ldots \ldots \ldots \ldots \ldots \ldots \ldots, 1$

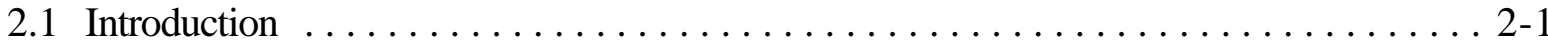

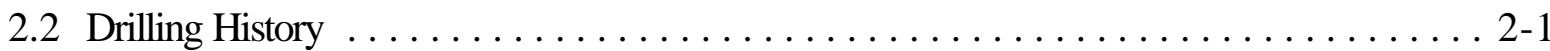

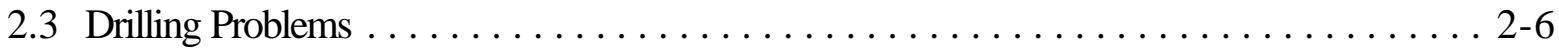

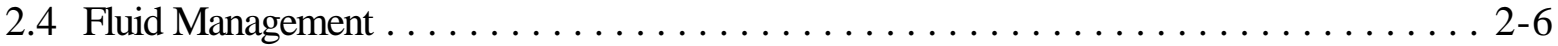

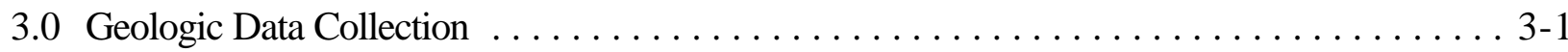

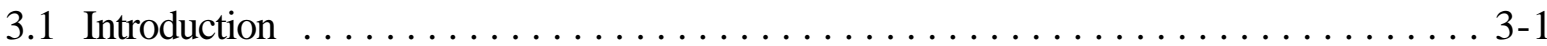

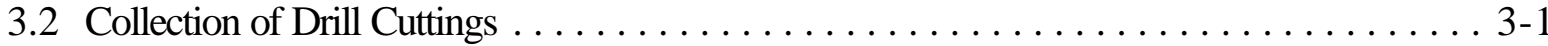

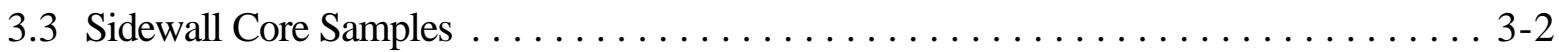

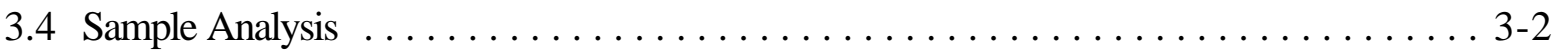

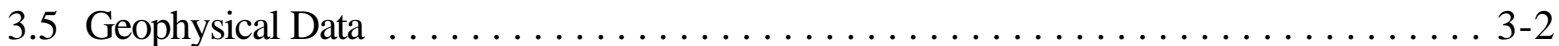

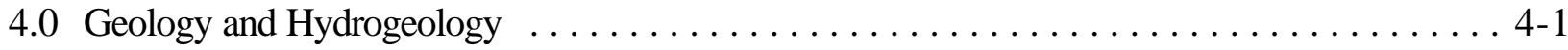

4.1 Introduction $\ldots \ldots \ldots \ldots \ldots \ldots \ldots \ldots \ldots \ldots \ldots \ldots \ldots \ldots \ldots \ldots \ldots \ldots \ldots \ldots \ldots \ldots \ldots, 1$

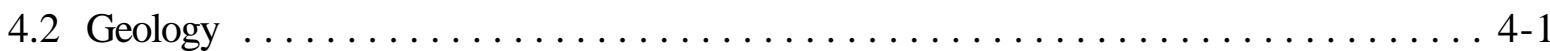

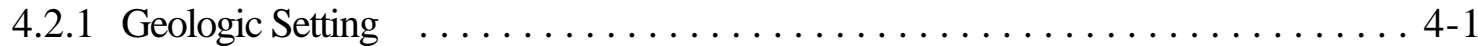

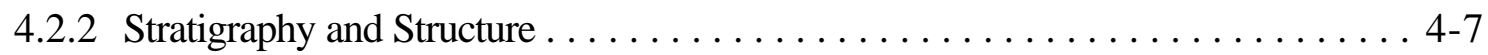

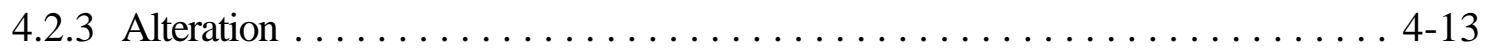

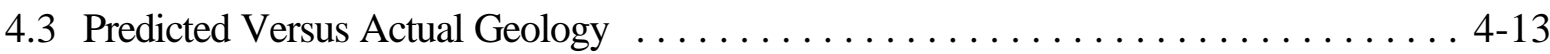

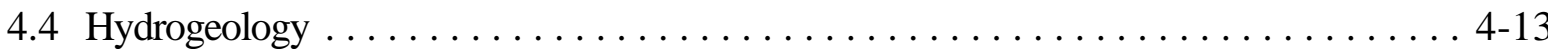




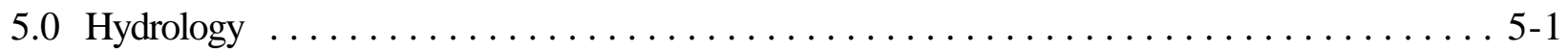

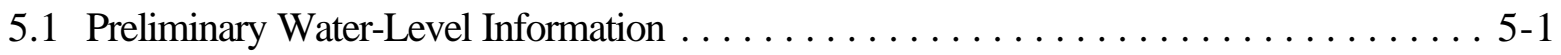

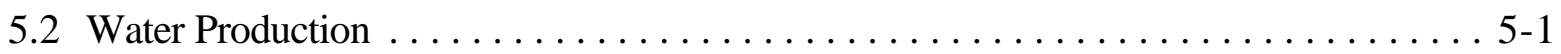

5.3 Preliminary Flow Meter Data $\ldots \ldots \ldots \ldots \ldots \ldots \ldots \ldots \ldots \ldots \ldots \ldots \ldots \ldots \ldots \ldots \ldots \ldots \ldots \ldots \ldots .1$

5.4 Preliminary Groundwater Characterization Sample $\ldots \ldots \ldots \ldots \ldots \ldots \ldots \ldots \ldots .2$

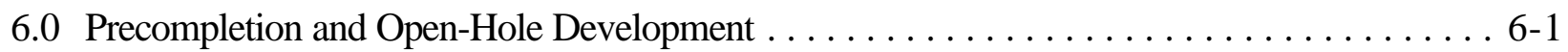

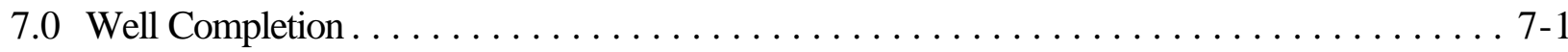

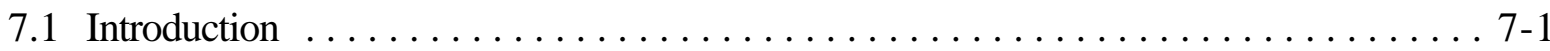

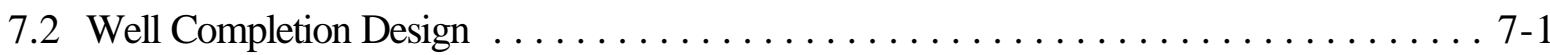

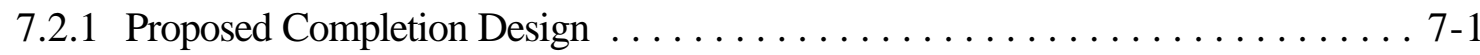

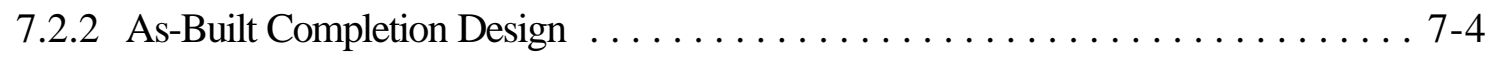

7.2.3 Rationale for Differences between Planned and Actual Well Design ........ . 7-4

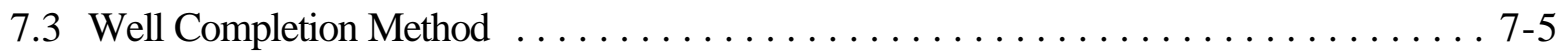

8.0 Actual versus Planned Costs and Scheduling $\ldots \ldots \ldots \ldots \ldots \ldots \ldots \ldots \ldots \ldots \ldots \ldots \ldots \ldots \ldots \ldots$

9.0 Summary, Recommendations, and Lessons Learned $\ldots \ldots \ldots \ldots \ldots \ldots \ldots \ldots . . \ldots \ldots$

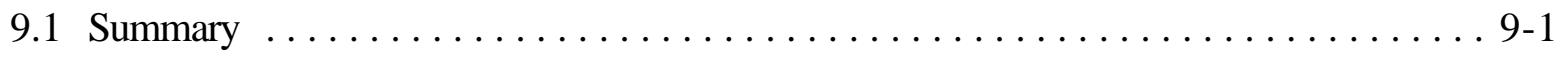

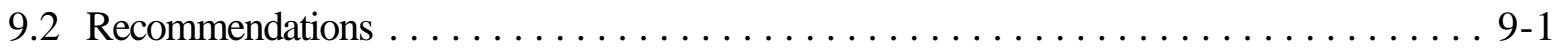

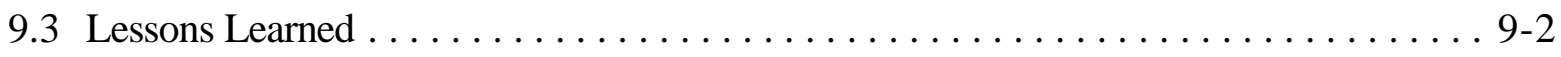

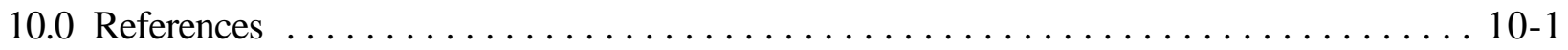

Appendix A - Drilling Data

A-1 Drilling Parameter Log for Well ER-7-1

A-2 Casing Data for Well ER-7-1

A-3 Well ER-7-1 Drilling Fluids and Cement Composition

Appendix B - Well ER-7-1 Fluid Management Data

Well ER-7-1 Fluid Disposition Reporting Form

Preliminary Analytical Results for Groundwater Characterization Sample from Well ER-7-1

Appendix C - Detailed Lithologic Log for Well ER-7-1

Appendix D - Geophysical Logs Run in Well ER-7-1

Distribution List 


\section{List of Figures}

Number

Title

Page

1-1 Reference Map Showing Location of Well ER-7-1 $\ldots \ldots \ldots \ldots \ldots \ldots \ldots$ 1-2

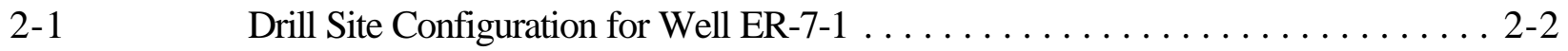

2-2 Well ER-7-1 Drilling and Completion History $\ldots \ldots \ldots \ldots \ldots \ldots \ldots \ldots \ldots \ldots$

4-1 Generalized Surface Geologic Map of the Nevada Test Site Area Showing Location of Well ER-7-1 . . . . . . . . . . . . . . . 4-3

4-2 Surface Geologic Map of the Well ER-7-1 Site $\ldots \ldots \ldots \ldots \ldots \ldots \ldots .4-5$

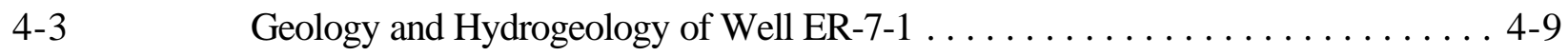

4-4 West-East Geologic Cross Section A-A' Through Well ER-7-1 . . . . . . . . 4-11

4-5 North-South Geologic Cross Section B-B' Through Well ER-7-1 . . . . . . 4-12

4-6 Predicted and Actual Stratigraphy at Well ER-7-1 . . . . . . . . . . . 4-14

4-7 West-East Hydrogeologic Cross Section C-C' Through Well ER-7-1 . . . . . 4-15

7-1 As-Built Completion Schematic for Well ER-7-1 …........... 7-2

7-2 Wellhead Diagram for Well ER-7-1 $\ldots \ldots \ldots \ldots \ldots \ldots \ldots \ldots \ldots \ldots \ldots \ldots \ldots \ldots$

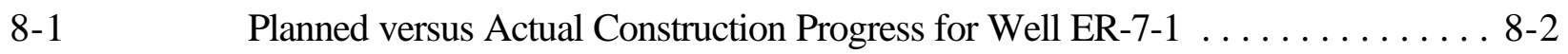

8-2 Planned versus Actual Cost for Constructing Well ER-7-1 $\ldots \ldots \ldots \ldots \ldots$ 8-3 


\section{List of Tables}

Number

Well ER-7-1 Site Data Summary $\ldots \ldots \ldots \ldots \ldots \ldots \ldots \ldots \ldots \ldots \ldots \ldots \ldots$

$2-1$

Abridged Drill Hole Statistics for Well ER-7-1 . . . . . . . . . . . . 2-5

3-1

Sidewall Samples from Well ER-7-1 . . . . . . . . . . . . . 3-3

$3-2$

Status of Rock Sample Analyses for Well ER-7-1 . . . . . . . . . . . . 3-5

$3-3$

Well ER-7-1 Geophysical Log Summary $\ldots \ldots \ldots \ldots \ldots \ldots \ldots \ldots$. . . . . . . .

7-1

Well ER-7-1 Completion String Construction Summary

. $7-4$

A-2

Casing Data for Well ER-7-1

A-3-1

Well ER-7-1 Drilling Fluids

A-3-1

A-3-2

Well ER-7-1 Cement Composition

D-1

Well ER-7-1 Geophysical Logs Presented

D-1 


\section{List of Acronyms and Abbreviations}

\begin{tabular}{|c|c|}
\hline $\mathrm{BN}$ & Bechtel Nevada \\
\hline $\mathrm{C}$ & centigrade \\
\hline $\mathrm{cm}$ & centimeter(s) \\
\hline DOE & U.S. Department of Energy \\
\hline $\mathrm{DOE} / \mathrm{NV}$ & U.S. Department of Energy, Nevada Operations Office \\
\hline DRI & Desert Research Institute \\
\hline $\mathrm{E}$ & east \\
\hline $\mathrm{EC}$ & Electrical Conductivity \\
\hline $\mathrm{F}$ & Fahrenheit \\
\hline FFACO & Federal Facilities Agreement and Consent Order \\
\hline FMP & Fluid Management Plan \\
\hline $\mathrm{ft}$ & foot (feet) \\
\hline gal & gallon(s) \\
\hline gpm & gallons per minute \\
\hline in. & inch(es) \\
\hline IT & IT Corporation \\
\hline LANL & Los Alamos National Laboratory \\
\hline LCA & lower carbonate aquifer \\
\hline lpm & liters per minute \\
\hline $\mathrm{LiBr}$ & lithium bromide \\
\hline $\mathrm{m}$ & meter(s) \\
\hline $\mathrm{N}$ & north \\
\hline NAD & North American Datum \\
\hline NNSA/NSO & National Nuclear Security Administration Nevada Site Office \\
\hline NTS & Nevada Test Site \\
\hline RWP & Radioactive Work Permit \\
\hline Shaw & Shaw Environmental Inc. \\
\hline $\mathrm{TD}$ & total depth \\
\hline TFM & thermal flow meter \\
\hline UGTA & Underground Test Area \\
\hline UDI & United Drilling, Inc. \\
\hline USGS & United States Geological Survey \\
\hline YF-LCU & Yucca Flat lower confining unit \\
\hline
\end{tabular}


This page intentionally left blank. 


\subsection{Introduction}

\subsection{Project Description}

Well ER-7-1 was drilled for the U.S. Department of Energy (DOE) National Nuclear Security Administration Nevada Site Office (NNSA/NSO; formerly Nevada Operations Office, DOE/NV) in support of the Nevada Environmental Restoration Project at the Nevada Test Site (NTS), Nye County, Nevada. Well ER-7-1 is the fourth in a series of five wells drilled in Fiscal Year 2003, as part of a hydrogeologic investigation program for the Yucca Flat/Climax Mine Corrective Action Unit Number 97. Data from these wells will allow for more accurate modeling of groundwater flow and radionuclide migration in the region. Some of the wells may also function as long-term monitoring wells.

The Yucca Flat hydrogeologic investigation well drilling program is part of the NNSA/NSO Environmental Restoration Division's Underground Test Area (UGTA) project at the NTS. The goals of the UGTA project include evaluating the nature and extent of contamination in groundwater due to underground nuclear testing, and establishing a long-term groundwater monitoring network. As part of the UGTA project, scientists are developing computer models to predict groundwater flow and contaminant migration within and near the NTS. To build and test these models, it is necessary to collect geologic, geophysical, and hydrologic data from new and existing wells to define groundwater migration pathways, migration rates, and quality.

The Yucca Flat hydrogeologic investigation well program is also part of the Corrective Action Investigation Plan (DOE/NV, 2000) for the Yucca Flat/Climax Mine Corrective Action Unit. The Corrective Action Investigation Plan is a requirement of the Federal Facility Agreement and Consent Order (FFACO, 1996) agreed to by the DOE, the Nevada Division of Environmental Protection, and the U.S. Department of Defense.

Well ER-7-1 is located in eastern Yucca Flat within the southeastern corner of NTS Area 7

(Figure 1-1). The elevation of the dirt-fill drill pad at the wellhead is 1,294.4 meters $(\mathrm{m})(4,246.7$ feet [ft]) above mean sea level. The Nevada State (central zone) plane coordinates (North American Datum [NAD] 1983) at the wellhead are North (N) 6,257,968.7 m and East (E) 559,622.5 m. Additional site data are listed in Table 1-1. 


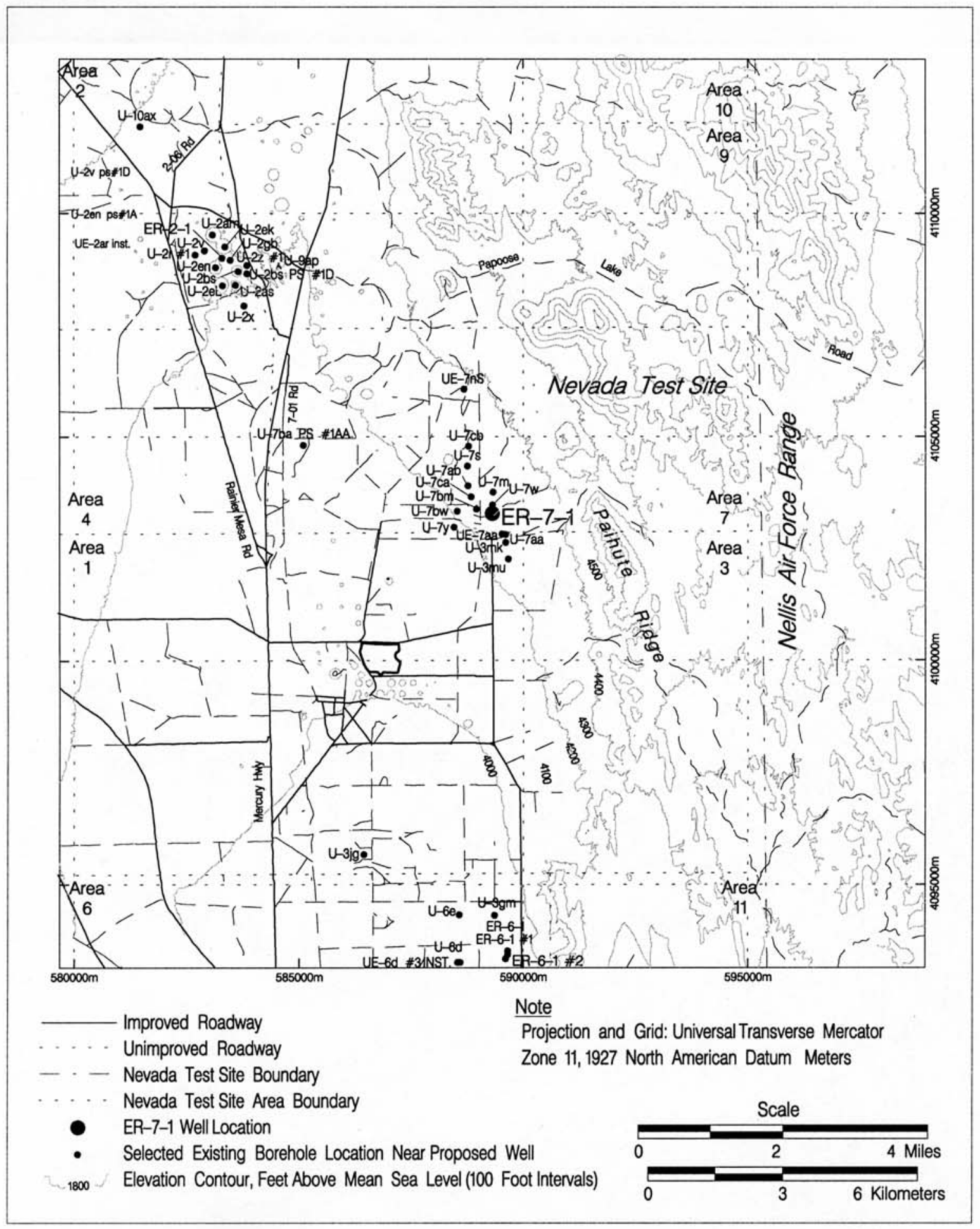

Figure 1-1

Reference Map Showing Location of Well ER-7-1 


\section{Table 1-1 \\ Well ER-7-1 Site Data Summary}

\begin{tabular}{|c|c|}
\hline Well Designation & ER-7-1 \\
\hline Site Coordinates ${ }^{a}$ & 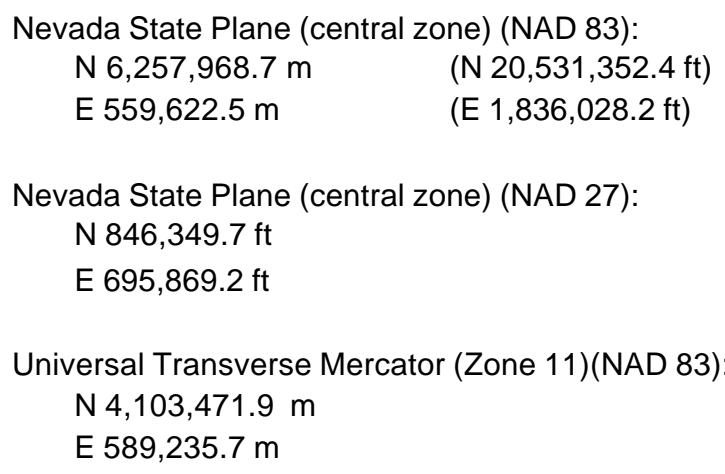 \\
\hline Surface Elevation ${ }^{b}$ & $1,294.4 \mathrm{~m}(4,246.7 \mathrm{ft})$ \\
\hline Drilled Depth & $762.0 \mathrm{~m}(2,500 \mathrm{ft})$ \\
\hline Fluid-Level Depth ${ }^{c}$ & $565.1 \mathrm{~m}(1,854 \mathrm{ft})$ \\
\hline Fluid-Level Elevation & $729.2 \mathrm{~m}(2,392.7 \mathrm{ft})$ \\
\hline
\end{tabular}

\footnotetext{
a Measurement made by BN Survey.

b Measurement made by BN Survey. Elevation at top of construction pad. 1929 National Geodetic Vertical Datum.

c Measured with density neutron log run on February 7, 2003, by Halliburton Energy Services.
}

Shaw Environmental (Shaw) (formerly IT Corp.; now succeeded by Stoller-Navarro Joint Venture) was the principal environmental contractor for the project, and Shaw personnel collected geologic and hydrologic data during drilling. The drilling company was United Drilling, Incorporated (UDI), a subcontractor to Bechtel Nevada (BN). Site supervision, engineering, construction, inspection, and geologic support were provided by BN. The roles and responsibilities of these and other contractors involved in the project are described in the BN Field Activity Work Plan D-001-001.03 (BN, 2002).

The UGTA Technical Working Group, a committee of scientists and engineers comprising NNSA/NSO, Lawrence Livermore National Laboratory, Los Alamos National Laboratory (LANL), and contractor personnel, provided additional technical advice during drilling, design, and construction of the well. See Yucca Flat Hydrogeologic Investigation Wells, Drilling and Completion Criteria (IT, 2002) for descriptions of the general plan and goals of the Yucca Flat project, as well as specific goals for each planned well. 
General guidelines for managing fluids used and generated during drilling, completion, and testing of UGTA wells are provided in the UGTA Fluid Management Plan (FMP) (DOE/NV, 2002). Management of solid waste (i.e., cuttings) is addressed in the UGTA Waste Management Plan (DOE/NV, 1996). Estimates of expected production of fluid and drill cuttings for the Yucca Flat holes are given in Appendix F of the drilling and completion criteria document for the Yucca Flat project (IT, 2002), along with sampling requirements and contingency plans for management of any hazardous waste produced. All activities were conducted according to the UGTA Health and Safety Plan (BN, 2001).

This report presents construction data and summarizes scientific data gathered during drilling and installation of the completion string. Some of the information in this report is preliminary and unprocessed, but is being released with the drilling and completion data for convenient reference. A well data report prepared by Shaw (Shaw, 2003) contains additional information on fluid management, waste management, and environmental compliance. Information on well development, aquifer testing, and groundwater analytical sampling will be compiled and disseminated separately.

\subsection{Objectives}

The primary purpose for constructing Well ER-7-1 was to evaluate the regional carbonate aquifer (lower carbonate aquifer [LCA]) down-gradient from an underground nuclear test conducted close to the LCA. The Well ER-7-1 site located within a cluster of underground nuclear tests, some of which were conducted near (and therefore, potentially connected hydraulically) the LCA. The closest of these tests is the TORRIDO test, which was conducted in Emplacement Hole U-7w. The well site is believed to be down-gradient from TORRIDO, which is located approximately $187.1 \mathrm{~m}(614 \mathrm{ft})$ to the north.

Of particular interest is the determination of whether there are permeable, near-vertical pathways (faults) along which radionuclides could migrate from individual underground tests to the underlying regional aquifer. The drilling criteria document (IT, 2002) presents all program objectives, and Appendix C of the document discusses the specific scientific objectives for Well ER-7-1, which include the following:

- Obtain geologic samples and geophysical data that will aid in defining and characterizing hydrostratigraphic units encountered. 
- Obtain fracture and other geologic data to aid the overall characterization of the LCA.

- Obtain aqueous geochemistry samples to establish the initial radiochemistry of groundwater within the LCA at this down-gradient position.

- Obtain water level data.

\subsection{Project Summary}

This section summarizes Well ER-7-1 construction operations; the details are provided in sections 2.0 through 8.0 of this report.

The conductor hole was constructed by augering a 91.4-centimeter- $(\mathrm{cm})$ (36-inch [in.]) diameter hole to a depth of $36.6 \mathrm{~m}(120 \mathrm{ft})$ and installing a string of 20-in. casing. Drilling of the surface hole with an $181 / 2$-in. rotary bit, using an air-water-foam fluid (with a polymer additive as necessary) in conventional circulation, began on January 27, 2003. A suitable depth to set the surface casing was reached at $541.0 \mathrm{~m}$ (1,775 ft). At this point, drilling was suspended for geophysical logging, and then the 13d -in. casing string was landed at $535.1 \mathrm{~m}$ (1,755.6 ft) on February 1, 2003. Drilling continued with a 121/4-in. bit to a total depth (TD) of $762.0 \mathrm{~m}$ (2,500 ft), which was reached on February 6, 2003. The planned TD of Well ER-7-1 was $670.6 \mathrm{~m}$ (2,200 ft), but because sufficient water had not been encountered by this depth, the borehole was deepened to accomplish the planned objectives.

Water production was first noted at a depth of approximately $695.3 \mathrm{~m}(2,281 \mathrm{ft})$, and reached a maximum of approximately 1,893 liters per minute (lpm) (500 gallons per minute [gpm]) near the bottom of the hole. The fluid level was measured at the depth of $565.1 \mathrm{~m}(1,854 \mathrm{ft})$ with the density neutron $\log$ on February 7, 2003. No radionuclides above background levels were encountered during drilling of Well ER-7-1.

Composite drill cuttings were collected every $3 \mathrm{~m}$ (10 ft) from $36.6 \mathrm{~m}(120 \mathrm{ft})$ to TD, and 62 sidewall core samples were taken at various depths below $85.3 \mathrm{~m}$ (280 ft). Open-hole geophysical logging of the well was conducted to help verify the geology and characterize the hydrology of the rocks. Some logs also aided in the construction of the well by providing borehole volume and conditions, and cement location. The well penetrated Quaternary and Tertiary surficial deposits; tuffs of the Timber Mountain Group, Paintbrush Group, Calico Hills Formation, Wahmonie Formation, Crater Flat Group, Belted Range Group, and Tunnel Formation; and carbonate sedimentary rocks of Paleozoic-age. 
A single completion string was installed in Well ER-7-1 on February 9, 2003. The string of carbonsteel, $7 \mathrm{e}$-in. production casing was landed at $756.4 \mathrm{~m}(2,481.7 \mathrm{ft})$. The bull-nosed string has one slotted interval at 664.1 to 756.4 (2,178.7 to $2,481.7 \mathrm{ft})$.

No pump was installed at the time of completion, but will be inserted as needed for hydrologic sampling and testing activities, which are beyond the scope of this report.

\title{
1.4 Project Manager
}

Inquiries concerning Well ER-7-1 should be directed to the UGTA Project Manager at:

\author{
U.S. Department of Energy \\ National Nuclear Security Administration \\ Nevada Site Office \\ Environmental Restoration Division \\ Post Office Box 98518 \\ Las Vegas, Nevada 89193-8518
}




\subsection{Drilling Summary}

\subsection{Introduction}

This section contains detailed descriptions of the drilling process and fluid management issues.

The general drilling requirements for all Yucca Flat wells in this series were provided in Yucca Flat Hydrogeologic Investigation Wells Drilling and Completion Criteria (IT, 2002). Specific requirements for Well ER-7-1 were outlined in Field Activity Work Plan D-001-001.03 (BN, 2002). Figure 2-1 shows the layout of the drill site. Figure 2-2 is a chart that illustrates the drilling and completion history for Well ER-7-1. Table 2-1 summarizes the drilling statistics for the well. The following information was compiled primarily from daily drilling reports provided by the BN Drilling Department.

\subsection{Drilling History}

Field operations at Well ER-7-1 began with the augering of a 91.4-cm (36-in.) conductor hole to $36.6 \mathrm{~m}$ ( $120 \mathrm{ft}$ ). A string of 20-in. casing was set at the depth of $36.6 \mathrm{~m}$ (120 ft). The bottom of the conductor casing was cemented inside to $29.0 \mathrm{~m}(95 \mathrm{ft})$, and the annulus was cemented from the bottom of the casing to ground level on November 20, 2002.

The UDI crews rigged up the Wilson Mogul 42B rig on January 23 through 27, 2003, and tagged cement inside the conductor casing at the depth of $29.0 \mathrm{~m}$ (95 ft). Drilling resumed through the cement and into the formation with an 181/2-in. rotary button bit, using air-foam with a polymer additive. The amounts of polymer and foaming agent in the drilling fluid, and the fluid injection rate, were adjusted as necessary during drilling to maintain superior circulation.

As a precaution against sloughing of the upper sections of unsaturated volcanic rocks, it was decided to install surface casing when a competent formation for supporting the casing was reached. On January 30, 2003, at a depth of $541.0 \mathrm{~m}$ (1,775 ft), drilling was halted to set the surface casing. The drillers circulated fluid to clean and condition the hole, pulled the drill string off the bottom, and waited about 30 minutes before tagging bottom again. Fill was encountered at $539.5 \mathrm{~m}(1,770 \mathrm{ft})$, then the drillers removed the drill string from the borehole. Drilling activity was suspended for 15 hours during geophysical logging prior to installation of the surface casing. 


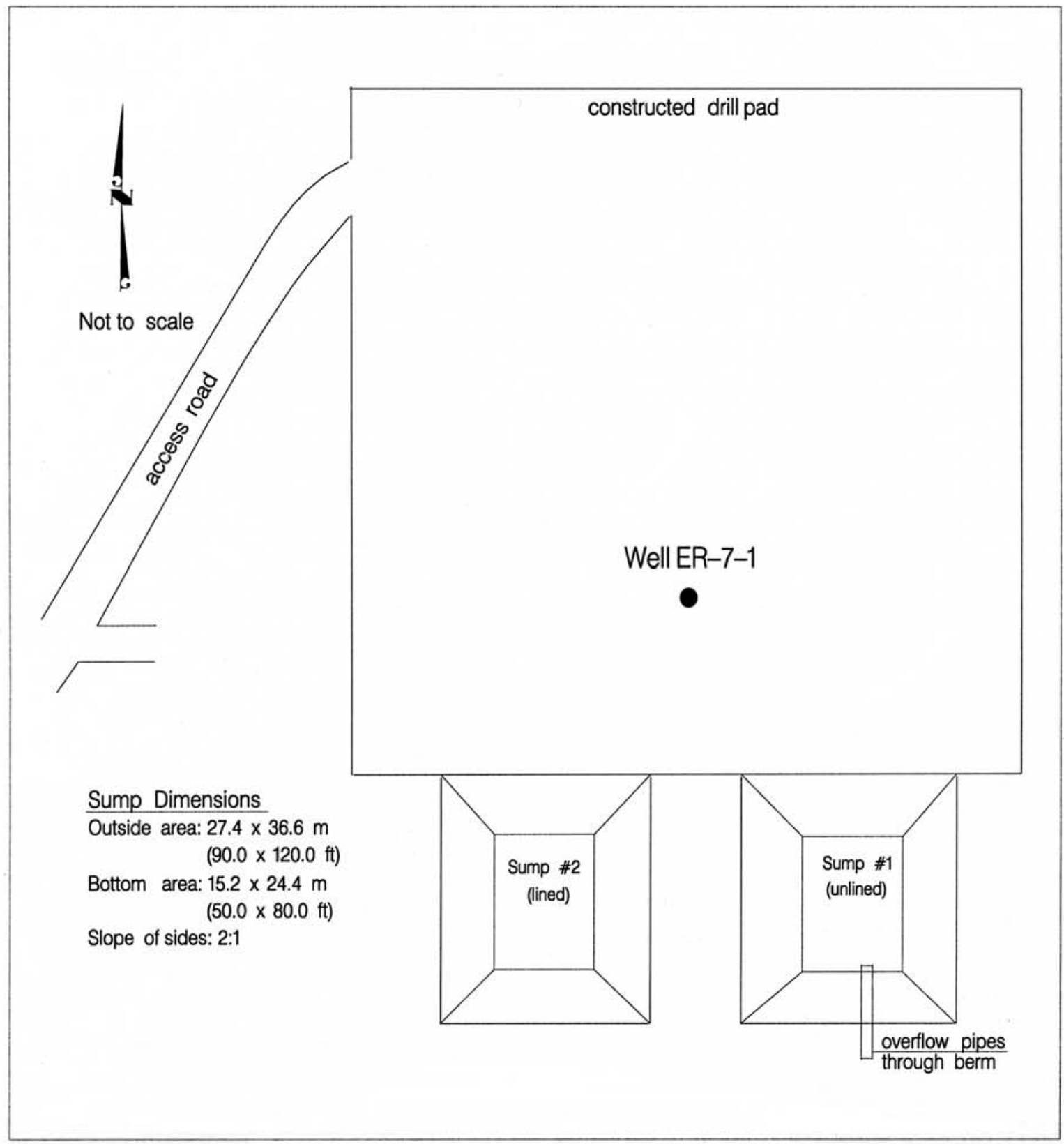

Figure 2-1

Drill Site Configuration for Well ER-7-1 
WELL ER-7-1 SUMMARY

$$
\text { Activity }
$$

Date

Begin drilling conductor hole:

Conductor hole completed and Begin drilling $181 / 2$-in. surface hole: Cace hole completed and 13 3/8-in. 01/27/2003 $02 / 05 / 200$ Begin drilling 12 1/4-in. intermediate hole: 02/04/2003 Reach total drilled depth of

$02 / 07 / 2003$

\section{LEGEND}

BHA Bottom hole assembly

DRI Desert Research Institute

$\mathrm{ft}$ foot (feet)

gpm gallons per minute

in. inch(es)

Ipm liters per minute

m meter(s)

TD Total depth

TIH Trip into hole

TOC Top of cement

TOH Trip out of hole

UDI United Drillers, Inc.

FIGURE 2-2

WELL ER-7-1

DRILLING AND COMPLETION

HISTORY \begin{tabular}{|l|l|l|l|l|l|l|l|l|l|l|l|l|l|l|l|l|l|l|l|l|l|l|l|} 
DAY & 1 & 2 & 3 & 4 & 5 & 6 & 7 & 8 & 9 & 10 & 11 & 12 & 13 & 14 & 15 & 16 & 17 & 18 & 19 & 20 & 21 & 22 & 23 \\
24 \\
\hline
\end{tabular}

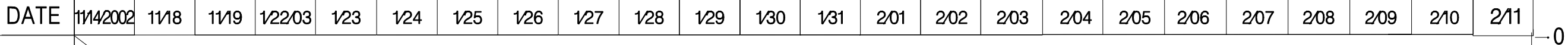

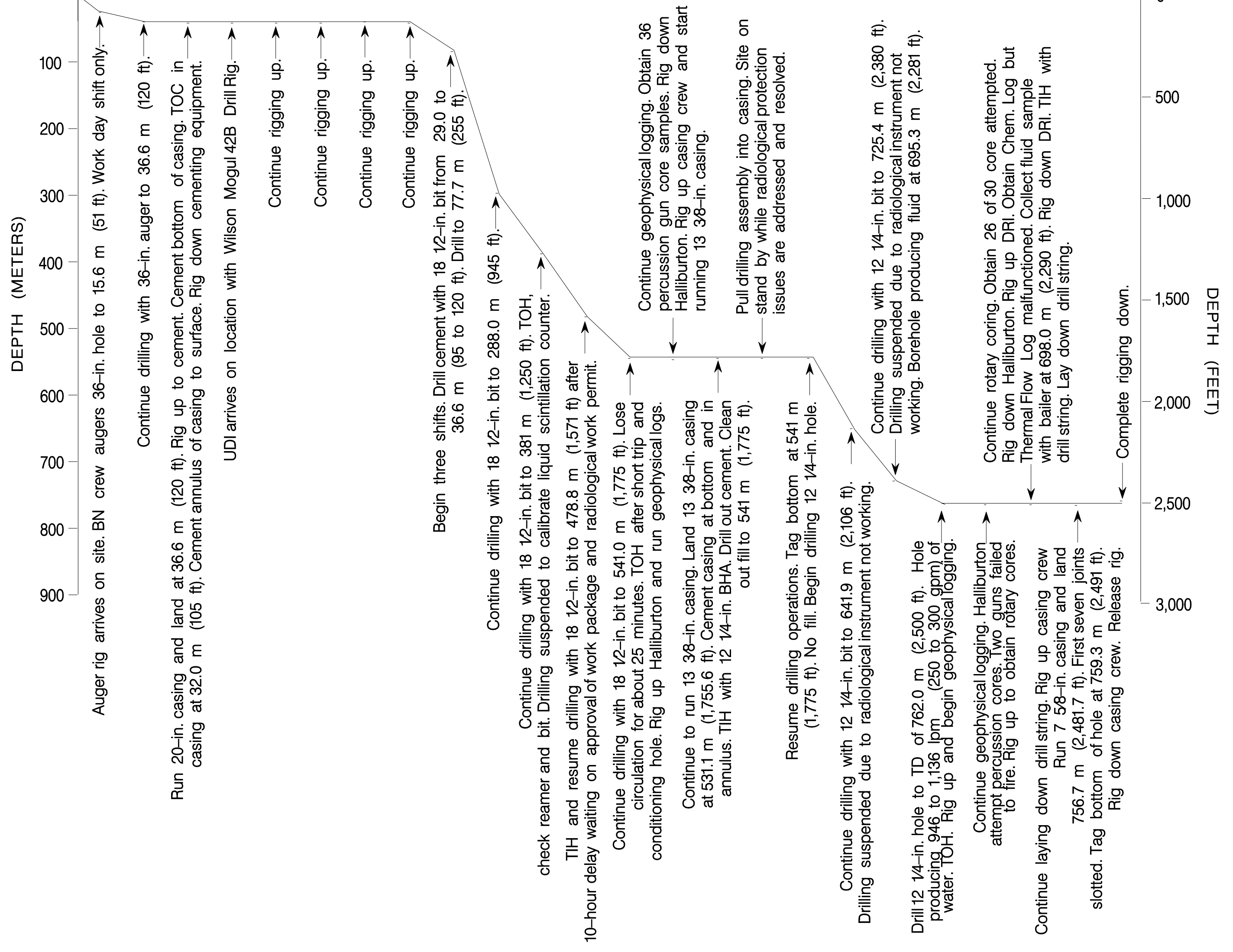

SHEET 1 OF 1 
This page intentionally left blank. 


\section{Table 2-1}

\section{Abridged Drill Hole Statistics for Well ER-7-1}

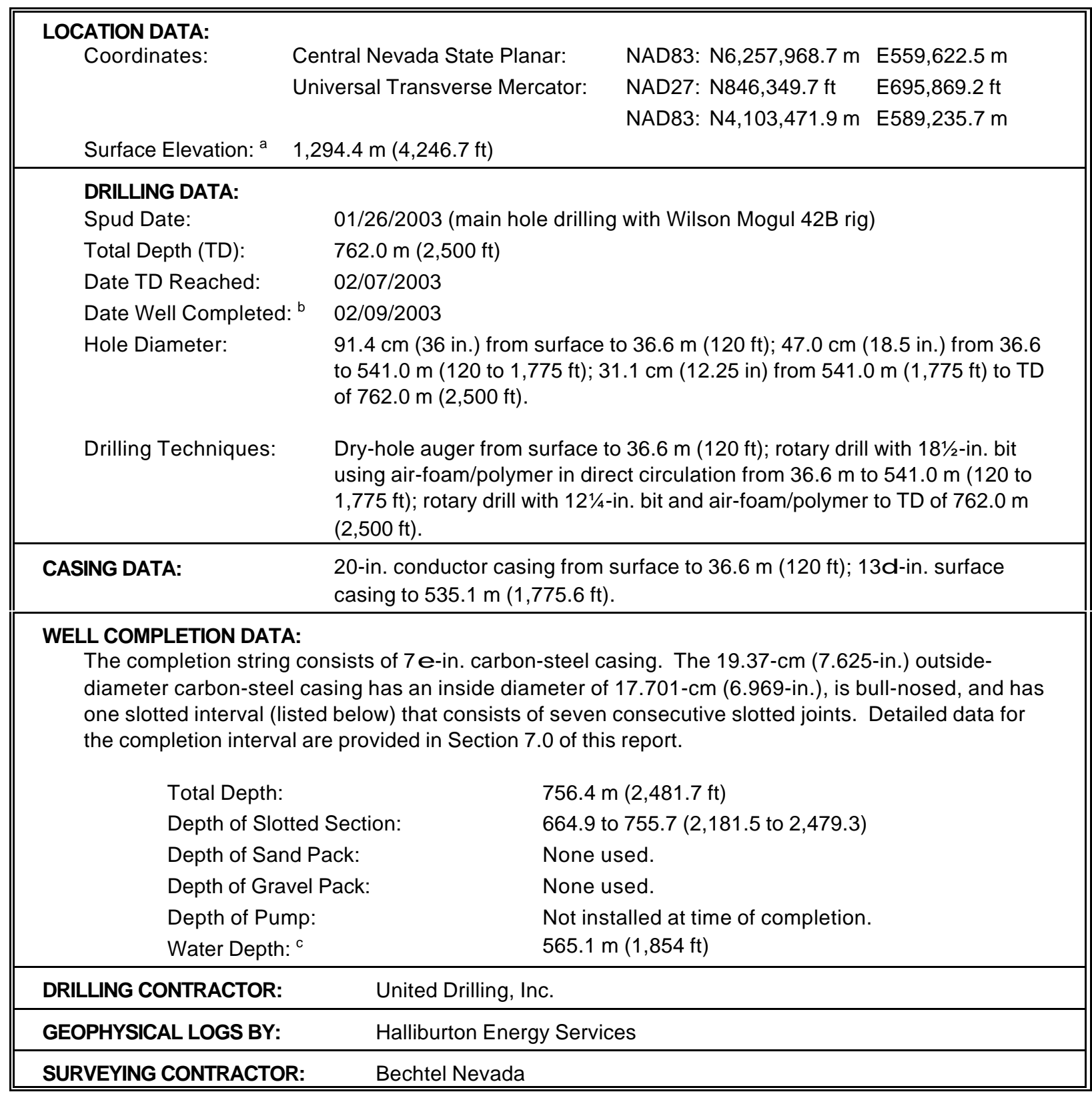

a Elevation of ground level at collar (1929 National Geodetic Vertical Datum).

b Date completion string as installed.

c Measured by Halliburton Energy Services on February 7, 2003. 
A casing subcontractor installed the $13 \mathrm{~d}$-in. casing. The casing was landed at a depth of $535.1 \mathrm{~m}$ $(1,755.6 \mathrm{ft})$ on February 2, 2003, above about $5.8 \mathrm{~m}(19 \mathrm{ft})$ of fill that had accumulated in the bottom of the surface hole during geophysical logging.

After the crew drilled out the cement and casing shoe, drilling operations were halted for a total of 39.5 hours on February 2-3, 2003, to address issues with Radioactive Work Permits (RWPs) and bioassays. When drilling resumed, no fill was encountered and the 121/4-in. borehole was advanced past the planned TD of $670.6 \mathrm{~m}(2,200 \mathrm{ft})$ because water had not yet been encountered. At

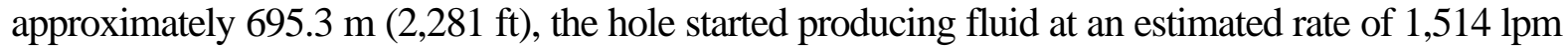
(400 gpm) and it was decided to drill to a new TD of $762.0 \mathrm{~m}(2,500 \mathrm{ft})$. The final TD was reached on February 6, 2003. Immediately after reaching TD, the drillers circulated fluid to condition the hole before the second phase of geophysical logging, which took place on February 7 through 9, 2003. Installation of the completion string began on February 9, 2003, and demobilization from the Well ER-7-1 site began on February 10, 2003.

The directional survey run inside the 7e -in. casing on April 14, 2003, indicates that at the lowest surveyed depth of $754.4 \mathrm{~m}(2,475 \mathrm{ft})$ the hole had drifted $5.4 \mathrm{~m}(17.6 \mathrm{ft})$ to the southeast of the well collar location. The borehole is relatively straight, with no "dog-legs."

A graphical depiction of drilling parameters, including penetration rate, revolutions per minute, pump pressure, and weight on bit, is presented in Appendix A-1. See Appendix A-2 for a listing of casing materials. Drilling fluids and cements used in Well ER-7-1 are listed in Appendix A-3.

\subsection{Drilling Problems}

No significant drilling problems were encountered at Well ER-7-1. Fill of generally less than $3 \mathrm{~m}$ (10 ft) was encountered only after non-drilling-related delays. Drilling continued $91.4 \mathrm{~m}(300 \mathrm{ft})$ past the planned TD because water had not been encountered, but this did not cause a significant delay.

\section{$2.4 \quad$ Fluid Management}

Drilling effluent was monitored according to the methods prescribed in the UGTA FMP (DOE/NV, 2002) and the associated site-specific strategy letter (Wycoff, 2003). The air-foam/polymer drill fluid was circulated down the inside of the drill string and back up the hole through the annulus (conventional or direct circulation) and then discharged into a sump. Water used to prepare drilling fluids came from Water Well 5B at the Hazardous Materials Spill Center and from the Radioactive Waste Management 
Site fill stand. Water from various NTS water wells on the site water well system feeds the fill stand, which may contain a variable mix of waters from Water Well 4 or Water Well 4a. Lithium bromide $(\mathrm{LiBr})$ was added to the drill fluid as a tracer to provide a means of estimating groundwater production. The rate of water inflow was estimated from the dilution of the tracer in the drill fluid returns.

To manage the anticipated water production, two sumps were constructed prior to drilling (Figure 2-1). Although the production of contaminants was considered unlikely, one of the sumps was lined with 40-millimeter, high density polyethylene prior to drilling (Bangerter, 2002). Samples of drilling effluent were tested on site hourly for the presence of tritium, and paint on down-hole tools was tested for lead prior to insertion in the borehole. The onsite monitoring results indicate that tritium remained at background levels (Shaw, 2003).

Before fluids are discharged to the ground surface, the FMP requires that a sample be collected and analyzed by an offsite laboratory to verify onsite monitoring data and demonstrate compliance with the FMP. At Well ER-7-1, the bulk of the fluids were discharged directly to the ground surface; therefore, the ground water characterization sample that was obtained from the depth of $698.0 \mathrm{~m}(2,290 \mathrm{ft})$ prior to installation of the completion string was used to demonstrate compliance with the FMP (Wurtz, 2003). The analytical results (Shaw, 2003) showed that discharged fluids were within the parameters of the FMP criteria. Water-quality data for this sample are given in Appendix B.

The results of analyses of samples of drilling fluid collected at Well ER-7-1 during drilling operations indicate that all fluid quality objectives were met, as shown on the fluid management reporting form dated February 11, 2003 (Appendix B). The form lists volumes of solids (drill cuttings) and fluids produced during well-construction operations, Stages I and II (i.e., vadose- and saturated-zone drilling only; well development and aquifer testing will be conducted at a later date). The volume of solids produced was calculated using the diameter of the borehole (from caliper logs) and the depth drilled, and includes added volume attributed to a rock bulking factor. The volumes of fluids listed on the report are estimates of total fluid production, and do not account for any infiltration or evaporation of fluids from the sumps. 
This page intentionally left blank. 


\subsection{Geologic Data Collection}

\subsection{Introduction}

This section describes the sources of geologic data obtained from Well ER-7-1 and the methods of data collection. Improving the understanding of the subsurface structure, stratigraphy, and hydrogeology in an area down-gradient from an underground nuclear test conducted close to the LCA was among the primary objectives of Well ER-7-1. The proper collection of geologic and hydrogeologic data from Well ER-7-1 was considered of prime importance to the completion of the project.

Geologic data collected at Well ER-7-1 consist of drill cuttings, sidewall core samples, and geophysical logs. Data collection, sampling, transfer, and documentation activities were performed according to applicable contractor procedures.

\subsection{Collection of Drill Cuttings}

Composite drill cuttings were collected from Well ER-7-1 at 3-m (10-ft) intervals as drilling progressed from the depth of $36.6 \mathrm{~m}$ (120 ft) to the TD of the well at $762.0 \mathrm{~m}$ (2,500 ft). Triplicate samples were collected from 238 intervals. In addition, the Shaw field representative collected two sets of reference samples from each of the cuttings intervals. One set was examined at the drill site for use in preparing field lithologic descriptions and remains in the custody of Stoller-Navarro Joint Venture. The other set was sent to LANL where it remains. Additionally, a larger composite drill cuttings sample (approximately 3.8 liters [ 1 gallon] in size) was collected while drilling through the pre-Tertiary carbonate rocks. Selected depths from this collection will be shipped to a commercial laboratory for paleontologic micro-fossil analysis to aid in the stratigraphic assignment of these rocks.

All other samples (i.e., 3 sets of 238 samples) are stored under secure, environmentally controlled conditions at the U.S. Geological Survey (USGS) Geologic Data Center and Core Library in Mercury, Nevada. One of these sample sets was sealed with custody tape at the rig site and remains sealed as an archive sample; one set was left unsealed in the original sample containers; and the third set was washed and stored according to standard USGS Core Library procedures. 


\subsection{Sidewall Core Samples}

Sidewall core samples were collected by Halliburton Energy Services from Well ER-7-1 to verify the stratigraphy and lithology at selected locations. Sample locations were selected by the Shaw field representative on the basis of field lithologic logs (with consideration of borehole conditions determined from caliper logs). A percussion gun tool was used to collect 36 sidewall cores in the upper $561.1 \mathrm{~m}$ $(1,841 \mathrm{ft})$ of the borehole on January 31,2003 , prior to installation of the surface casing. Before the completion string was installed, Halliburton collected 25 rotary sidewall cores from the lower part of the borehole. Table 3-1 lists the recovery and stratigraphic assignment for each sample.

\subsection{Sample Analysis}

Composite samples of drill cuttings from various depths in Well ER-7-1 were submitted to the LANL Earth and Environmental Sciences Division - Geology and Geochemistry laboratories for petrographic, mineralogic, and chemical analysis to aid in stratigraphic identification and for characterization of mineral alteration. The status of these analyses is shown in Table 3-2.

\subsection{Geophysical Data}

Geophysical logs were run in the Well ER-7-1 borehole to further characterize the lithology, structure, and water content of the rocks encountered. In addition, logs were run to evaluate borehole conditions and to determine the fluid levels during the course of drilling. Geophysical logging was conducted during two stages of drilling and completion: before installation of the surface casing and before installation of the well completion casing. Some logs were run in both the saturated and unsaturated zones of the borehole, while others were run in only the saturated interval. A complete listing of the logs, dates run, depths, and service companies is provided in Table 3-3. The logs are available from BN in Mercury, Nevada, and copies are on file at the office of Stoller-Navarro Joint Venture in Las Vegas, Nevada. Preliminary geophysical data from the logs are reproduced in Appendix D.

The overall quality of the geophysical data collected was good, though the sonic log is considered invalid above the depth of $701.0 \mathrm{~m}(2,300 \mathrm{ft})$ due to turbulence in the fluid column. Technical problems that could not be corrected onsite were encountered with some tools. 
Table 3-1

Sidewall Samples from Well ER-7-1 (Page 1 of 2)

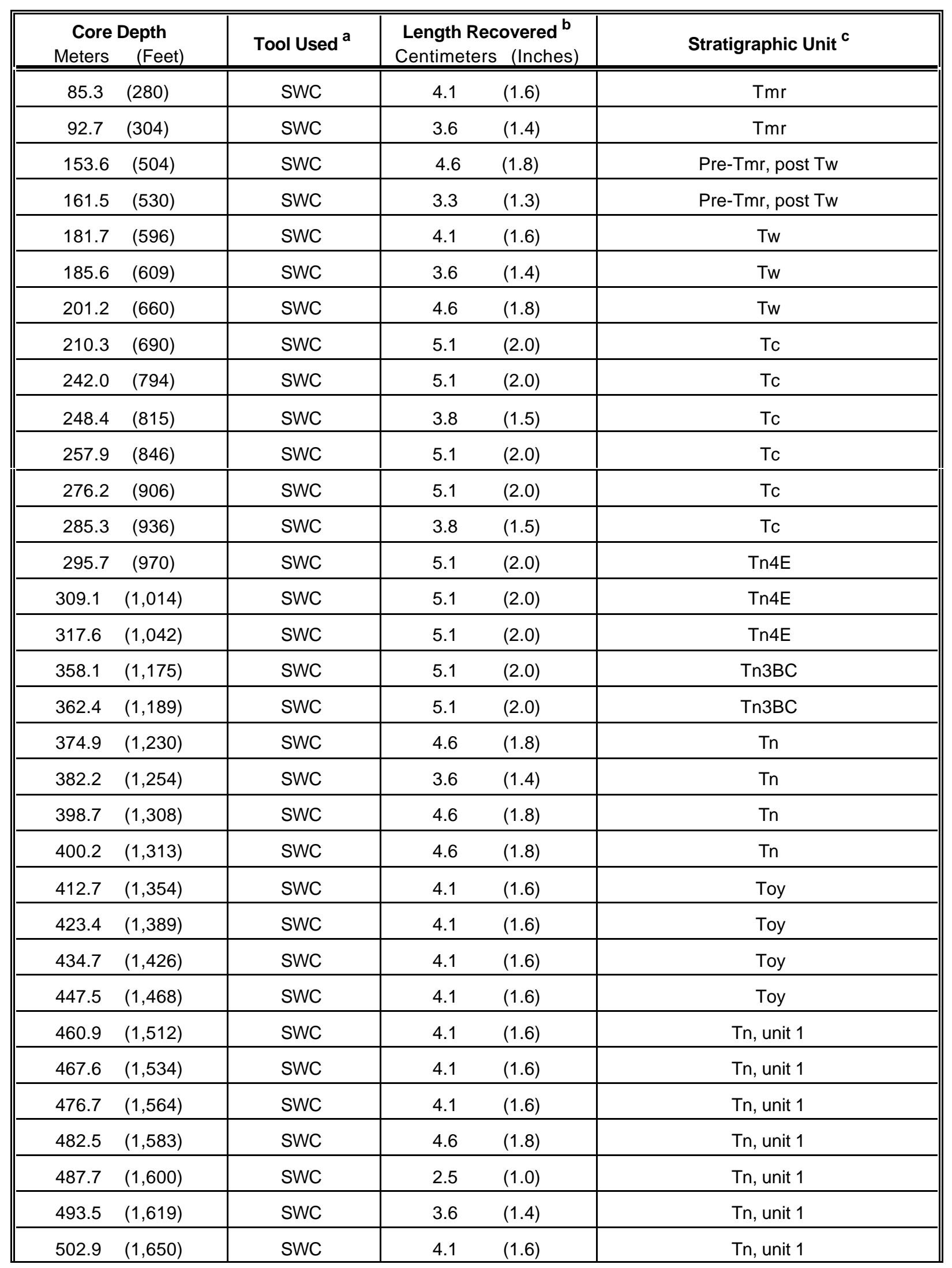


Table 3-1

Sidewall Samples from Well ER-7-1 (Page 2 of 2)

\begin{tabular}{|c|c|c|c|c|c|}
\hline \multicolumn{2}{|c|}{\begin{tabular}{cc}
\multicolumn{2}{c}{ Core Depth } \\
Meters $\quad$ (Feet)
\end{tabular}} & \multirow{2}{*}{$\frac{\text { Tool Used }^{\mathbf{a}}}{\text { SWC }}$} & \multicolumn{2}{|c|}{$\begin{array}{l}\text { Length Recovered } \\
\text { Centimeters (Inches) } \\
\end{array}$} & Stratigraphic Unit ${ }^{c}$ \\
\hline 506.6 & $(1,662)$ & & 4.6 & $(1.8)$ & Tn, unit 1 \\
\hline 530.1 & $(1,739)$ & SWC & 5.1 & (2.0) & $\mathrm{Pz}$ \\
\hline 533.4 & $(1,750)$ & SWC & 5.1 & (2.0) & $\mathrm{Pz}$ \\
\hline 561.1 & $(1,841)$ & MSCT & 4.6 & (1.8) & $\mathrm{Pz}$ \\
\hline 563.0 & $(1,847)$ & MSCT & 4.6 & (1.8) & $\mathrm{Pz}$ \\
\hline 568.2 & $(1,864)$ & MSCT & 4.1 & $(1.6)$ & $\mathrm{Pz}$ \\
\hline 577.0 & $(1,893)$ & MSCT & 4.1 & (1.6) & $\mathrm{Pz}$ \\
\hline 581.3 & $(1,907)$ & MSCT & 3.1 & $(1.2)$ & $\mathrm{Pz}$ \\
\hline 583.1 & $(1,913)$ & MSCT & 5.0 & $(2.0)$ & $\mathrm{Pz}$ \\
\hline 590.1 & $(1,936)$ & MSCT & 4.9 & (1.9) & $\mathrm{Pz}$ \\
\hline 593.4 & $(1,947)$ & MSCT & 4.6 & $(1.8)$ & $\mathrm{Pz}$ \\
\hline 600.5 & $(1,970)$ & MSCT & 3.8 & (1.5) & $\mathrm{Pz}$ \\
\hline 603.8 & $(1,981)$ & MSCT & 3.6 & (1.4) & $\mathrm{Pz}$ \\
\hline 605.0 & $(1,985)$ & MSCT & 3.3 & (1.3) & $\mathrm{Pz}$ \\
\hline 608.4 & $(1,996)$ & MSCT & 4.8 & (1.9) & $\mathrm{Pz}$ \\
\hline 613.9 & $(2,014)$ & MSCT & 3.6 & (1.4) & $\mathrm{Pz}$ \\
\hline 630.3 & $(2,068)$ & MSCT & 3.6 & (1.4) & $\mathrm{Pz}$ \\
\hline 640.1 & $(2,100)$ & MSCT & 4.6 & (1.8) & $\mathrm{Pz}$ \\
\hline 672.7 & $(2,207)$ & MSCT & 2.8 & $(1.1)$ & $\mathrm{Pz}$ \\
\hline 679.7 & $(2,230)$ & MSCT & 4.1 & (1.6) & $\mathrm{Pz}$ \\
\hline 684.9 & $(2,244)$ & MSCT & 5.1 & (2.0) & $\mathrm{Pz}$ \\
\hline 700.1 & $(2,297)$ & MSCT & 4.3 & (1.7) & $\mathrm{Pz}$ \\
\hline 711.1 & $(2,333)$ & MSCT & 4.1 & $(1.6)$ & $\mathrm{Pz}$ \\
\hline 717.8 & $(2,355)$ & MSCT & 3.8 & $(1.5)$ & $\mathrm{Pz}$ \\
\hline 734.3 & $(2,409)$ & MSCT & 4.1 & $(1.6)$ & $\mathrm{Pz}$ \\
\hline 737.9 & $(2,421)$ & MSCT & 4.3 & $(1.7)$ & $\mathrm{Pz}$ \\
\hline 750.7 & $(2,463)$ & MSCT & 3.6 & (1.4) & $\mathrm{Pz}$ \\
\hline 754.1 & $(2,474)$ & MSCT & 4.1 & $(1.6)$ & $\mathrm{Pz}$ \\
\hline
\end{tabular}

a $\quad$ SWC $=$ Percussion sidewall gun; $\mathbf{M S C T}=$ Rotary mechanical sidewall coring tool. Both tools operated by Halliburton Energy Services.

b Estimated.

c Preliminary assignments. Tmr $=$ Rainier Mesa Tuff; Pre-Tmr post Tw $=$ Pre-Rainier, Mesa post-Wahmonie Tuff; Tw = Wahmonie Tuff; Tc = Crater Flat Tuffs; Tn4E = Tunnel 4 member, Bed E (equivalent); $\mathbf{T n}=$ Tunnel beds, undifferentiated; Toy = Tuff of Yucca Flat; Tn, unit 1 = Tunnel bed $1 ; \mathbf{P z}=$ Paleozoic sedimentary rocks, undivided. 
Table 3-2

Status of Rock Sample Analyses for Well ER-7-1

\begin{tabular}{|c|c|c|c|c|c|}
\hline \multirow{3}{*}{$\begin{array}{l}\text { Depth }^{\mathbf{a}} \\
\text { meters (feet) }\end{array}$} & \multicolumn{5}{|c|}{ Analyses Performed ${ }^{b}$} \\
\hline & \multirow{2}{*}{$\begin{array}{c}\text { Petrographic } \\
\text { PTS } \\
\end{array}$} & \multicolumn{2}{|c|}{ Mineralogic } & \multicolumn{2}{|c|}{ Chemical } \\
\hline & & MP & XRD & XRF & $\mathrm{Fe}^{2+} / \mathrm{Fe}^{3+}$ \\
\hline $57.9 \quad(190)$ & C & C & $\mathrm{N} / \mathrm{P}$ & $\mathrm{N} / \mathrm{P}$ & $\mathrm{N} / \mathrm{P}$ \\
\hline $91.4 \quad(300)$ & $\mathrm{C}$ & $\mathrm{C}$ & $\mathrm{C}$ & $\mathrm{C}$ & $\mathrm{C}$ \\
\hline $149.4 \quad(490)$ & $\mathrm{C}$ & $\mathrm{C}$ & $\mathrm{C}$ & $\mathrm{C}$ & $\mathrm{C}$ \\
\hline $189.0 \quad(620)$ & $\mathrm{C}$ & NP & $\mathrm{C}$ & C & C \\
\hline $201.2 \quad(660)$ & $\mathrm{C}$ & NP & $\mathrm{C}$ & $\mathrm{C}$ & $\mathrm{C}$ \\
\hline $216.4 \quad(710)$ & $\mathrm{C}$ & NP & $\mathrm{C}$ & C & C \\
\hline $237.7 \quad(780)$ & $\mathrm{C}$ & NP & $\mathrm{C}$ & $\mathrm{C}$ & $\mathrm{C}$ \\
\hline $262.1 \quad(860)$ & $\mathrm{C}$ & C & $\mathrm{C}$ & C & C \\
\hline $277.4 \quad(910) A$ & $\mathrm{C}$ & NP & $\mathrm{C}$ & $\mathrm{C}$ & $\mathrm{C}$ \\
\hline $277.4 \quad(910) B$ & $\mathrm{C}$ & NP & C & C & C \\
\hline $310.9 \quad(1,020)$ & $\mathrm{C}$ & $\mathrm{C}$ & $\mathrm{C}$ & $\mathrm{C}$ & $\mathrm{C}$ \\
\hline $353.6 \quad(1,160)$ & $\mathrm{C}$ & NP & $\mathrm{C}$ & $\mathrm{C}$ & $\mathrm{C}$ \\
\hline $371.9 \quad(1,220)$ & C & $\mathrm{NP}$ & C & $\mathrm{C}$ & $\mathrm{C}$ \\
\hline $378.0 \quad(1,240)$ & C & $\mathrm{NP}$ & C & C & $\mathrm{C}$ \\
\hline $414.5 \quad(1,360)$ & $\mathrm{C}$ & NP & $\mathrm{C}$ & $\mathrm{C}$ & $\mathrm{C}$ \\
\hline $429.8 \quad(1,410)$ & C & $\mathrm{C}$ & $\mathrm{C}$ & $\mathrm{C}$ & $\mathrm{C}$ \\
\hline $463.3 \quad(1,520)$ & C & $\mathrm{C}$ & C & $\mathrm{C}$ & C \\
\hline $502.9 \quad(1,650)$ & C & C & C & C & $\mathrm{C}$ \\
\hline $506.0 \quad(1,660)$ & $\mathrm{C}$ & NP & $\mathrm{C}$ & $\mathrm{C}$ & C \\
\hline $515.1 \quad(1,690)$ & C & $\mathrm{NP}$ & C & C & C \\
\hline $551.7 \quad(1,810)$ & $\mathrm{C}$ & NP & $\mathrm{N} / \mathrm{P}$ & $\mathrm{N} / \mathrm{P}$ & $\mathrm{N} / \mathrm{P}$ \\
\hline $752.9 \quad(2,470)$ & C & NP & $\mathrm{N} / \mathrm{P}$ & $\mathrm{N} / \mathrm{P}$ & $\mathrm{N} / \mathrm{P}$ \\
\hline
\end{tabular}

a Depth represents base of 3-m (10-ft) sample interval for drill cuttings. All samples are drill cuttings that represent the lithologic character of the interval.

b Status of analyses: $\mathbf{C}=$ analysis complete; $\mathbf{P}=$ analysis pending; $\mathbf{N P}=$ analysis not planned.

Analysis type: $\mathbf{P T S}=$ polished thin section; $\mathbf{M P}=$ electron microprobe; $\mathbf{X R D}=\mathbf{x}$-ray diffraction; $\mathbf{X R F}=\mathbf{x}$-ray fluorescence; $\mathrm{Fe}^{2+} / \mathrm{Fe}^{3+}=$ wet chemical analysis for iron. 
Table 3-3

Well ER-7-1 Geophysical Log Summary

\begin{tabular}{|c|c|c|c|c|c|c|}
\hline Geophysical Log Type ${ }^{a}$ & Log Purpose & $\begin{array}{l}\text { Logging } \\
\text { Service }\end{array}$ & $\begin{array}{l}\text { Date } \\
\text { Logged }\end{array}$ & Run Number & $\begin{array}{l}\text { Bottom of } \\
\text { Logged } \\
\text { Interval } \\
\text { meters (feet) }\end{array}$ & $\begin{array}{l}\text { Top of Logged } \\
\text { Interval c } \\
\text { meters (feet) }\end{array}$ \\
\hline $\begin{array}{l}\text { * Natural Gamma Ray } \\
\text { Spectroscopy }\end{array}$ & $\begin{array}{l}\text { Stratigraphic correlation, mineralogy, } \\
\text { natural and man-made radiation }\end{array}$ & HES & $\begin{array}{l}01 / 31 / 2003 \\
02 / 07 / 2003\end{array}$ & $\begin{array}{l}\text { SGR-1/GR-3 } \\
\text { SGR-2/GR-7 }\end{array}$ & $\begin{array}{l}527.0(1,729) \\
746.8(2,450)\end{array}$ & $\begin{array}{c}26.2(86) \\
579.4(1,704)\end{array}$ \\
\hline * Gamma Ray / Six Arm Caliper & $\begin{array}{l}\text { Stratigraphic correlation, mineralogy, } \\
\text { natural and man-made radiation }\end{array}$ & HES & $\begin{array}{l}01 / 31 / 2003 \\
02 / 07 / 2003\end{array}$ & $\begin{array}{l}\text { GR-2/CA6-1 } \\
\text { GR-6/CA6-2 }\end{array}$ & $\begin{array}{l}536.5(1,760) \\
756.5(2,482)\end{array}$ & $\begin{array}{c}15.2(50) \\
487.7(1,600)\end{array}$ \\
\hline $\begin{array}{l}\text { * Epithermal Neutron / Density / } \\
\text { Gamma Ray / Caliper }\end{array}$ & $\begin{array}{l}\text { Total water content/borehole } \\
\text { conditions }\end{array}$ & HES & $\begin{array}{l}01 / 31 / 2003 \\
02 / 07 / 2003\end{array}$ & $\begin{array}{l}\text { DSEN-1/SDL-1/ GR-4 } \\
\text { DSEN-2/SDL-2/ GR-8 }\end{array}$ & $\begin{array}{l}538.9(1,768) \\
759.3(2,491)\end{array}$ & $\begin{array}{c}13.7(45) \\
518.2(1,700.0)\end{array}$ \\
\hline * High Resolution Induction & $\begin{array}{l}\text { Rock porosity, lithologic determination } \\
\text { / stratigraphic correlation }\end{array}$ & HES & $01 / 31 / 2003$ & HRI-1/GR-3 & $537.4(1,763)$ & $36.6(120)$ \\
\hline $\begin{array}{l}\text { * Dual Laterolog / Gamma Ray / } \\
\text { * Spontaneous Potential }\end{array}$ & $\begin{array}{l}\text { Saturated zone: water saturation/ } \\
\text { stratigraphic correlation }\end{array}$ & HES & $02 / 07 / 2003$ & DLL-1/GR-7/SP-1 & $755.3(2,478)$ & $519.7(1,705)$ \\
\hline Electro Microlmager / Gamma Ray & $\begin{array}{l}\text { Saturated zone: lithologic } \\
\text { characterization, fracture and void } \\
\text { analysis/stratigraphic correlation }\end{array}$ & HES & $02 / 07 / 2003$ & FMI-1/GR-6 & $756.5(2,482)$ & $541.3(1,776)$ \\
\hline Temperature / Gamma Ray & $\begin{array}{l}\text { Saturated zone: groundwater } \\
\text { temperature/stratigraphic correlation }\end{array}$ & HES & $\begin{array}{l}01 / 31 / 2003 \\
02 / 07 / 2003\end{array}$ & $\begin{array}{l}\text { TL-1/GR-1 } \\
\text { TL-2/GR-5 }\end{array}$ & $\begin{array}{l}522.4(1,714) \\
743.7(2,440)\end{array}$ & $\begin{array}{c}0 \\
426.7(1,400)\end{array}$ \\
\hline $\begin{array}{l}\text { Gamma Ray / Digital Array Sonic } \\
\text { A. Wave-form presentations } \\
{ }^{*} \text { B. Sonic porosity and travel time } \\
\text { computations }\end{array}$ & $\begin{array}{l}\text { Saturated zone: } \\
\text { A. Porosity, lithologic determination } \\
\text { B. Fracture identification }\end{array}$ & HES & $02 / 07 / 2003$ & GR-9/FWS-1 & $756.2(2,481)$ & $518.2(1,700)$ \\
\hline Mechanical Sidewall Coring Tool & Geologic samples & HES & $02 / 07 / 2003$ & RSWC-1 & $754.1(2,474)$ & $518.2(1,700)$ \\
\hline Percussion Sidewall Coring Gun & Geologic samples & HES & $03 / 31 / 2003$ & SWC-1 & $533.4(1,750)$ & $85.3(280)$ \\
\hline Thermal Flow Log & $\begin{array}{l}\text { Rate and direction of groundwater flow } \\
\text { in borehole }\end{array}$ & DRI & $02 / 09 / 2003$ & TFM-2 & $579.1(1,900)$ & $579.1(1,900)$ \\
\hline${ }^{*}$ Chemistry Log & $\begin{array}{l}\text { Groundwater chemistry, formation } \\
\text { transmissivity }\end{array}$ & DRI & $02 / 08 / 2003$ & CHEM-1/TL-3 & $761.4(2,498)$ & $565.1(1,854)$ \\
\hline Gyroscopic Directional Survey & Borehole deviation & $\mathrm{BHI}$ & $04 / 14 / 2003$ & DRG-1 & $754.4(2,475)$ & 0 \\
\hline
\end{tabular}

a Logs presented in geophysical log summary, Appendix $D$, are indicated by *.

HES = Halliburton Energy Services; DRI = Desert Research Institute; $\mathbf{B H I}=$ Baker Hughes Inteq

c Depth below ground surface. 


\subsection{Geology and Hydrogeology}

\subsection{Introduction}

This section summarizes the geology and hydrogeology of Well ER-7-1. The basis for these discussions is the detailed lithologic log presented in Appendix C. The detailed lithologic log was developed using drill cuttings and sidewall core samples, geophysical logs, and drilling parameters. Results from petrographic, mineralogic, and chemical analyses provided by Giday WoldeGabriel of LANL for select lithologic samples (WoldeGabriel, 2003) were incorporated into the lithologic log.

\subsection{Geology}

This section is subdivided into discussions of the stratigraphic section and structural features interpreted from Well ER-7-1 data, followed by a discussion of alteration noted in samples from the well.

\subsubsection{Geologic Setting}

Well ER-7-1 is located in south-central Area 7 in eastern Yucca Flat (Figure 4-1). Yucca Flat is a typical basin of the Basin and Range physiographic province, which is characterized by a series of tilted fault blocks resulting in longitudinal mountain ranges and broad intervening basins. In the vicinity of the NTS, the basins and ranges generally trend north-south. Yucca Flat formed as a result of Cenozoic movement and subsequent rotation along mostly normal faults. The basin is currently being filled with alluvial debris eroded from the surrounding mountains. The alluvium has buried a relatively thick sequence of east-dipping Tertiary volcanic rocks whose sources are various calderas in the region. The volcanic rocks are underlain by a thick sequence of Paleozoic miogeosynclinal rocks consisting of mostly carbonates (Gonzales et al., 1998). Figure 4-2 shows the surface geology mapped in the immediate vicinity of Well ER-7-1.

The Yucca Flat geologic quadrangle map (Colton and McKay, 1966) depicts the simple surface geology in this part of Yucca Flat. The sedimentary and volcanic terrains east of the site are illustrated on the Paiute Ridge geologic quadrangle map by Byers and Barnes (1967). Limestone and dolostone of Ordovician and Cambrian age outcrop 1,830 m (6,000 ft) to the east (Slate et al., 1999).

Well ER-7-1 penetrated $65.5 \mathrm{~m}$ (215.0 ft) of Quaternary and Tertiary tuffaceous alluvial deposits above $443.5 \mathrm{~m}(1,455.0 \mathrm{ft})$ of Tertiary volcanic rocks. Below the Tertiary-age volcanic rocks, the 
This page intentionally left blank. 


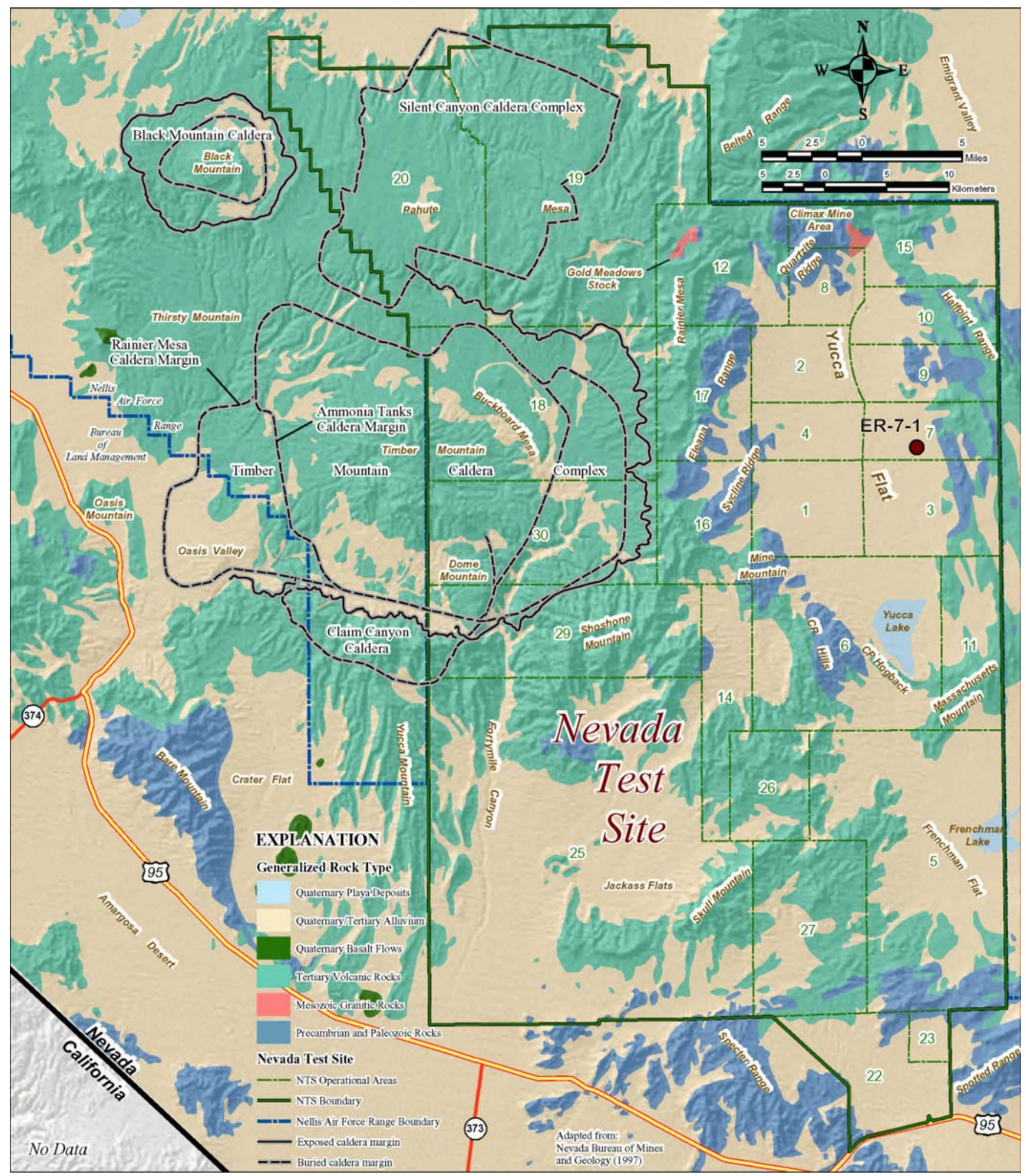

Figure 4-1

Generalized Surface Geologic Map of the Nevada Test Site Area Showing Location of Well ER-7-1 
This page intentionally left blank. 


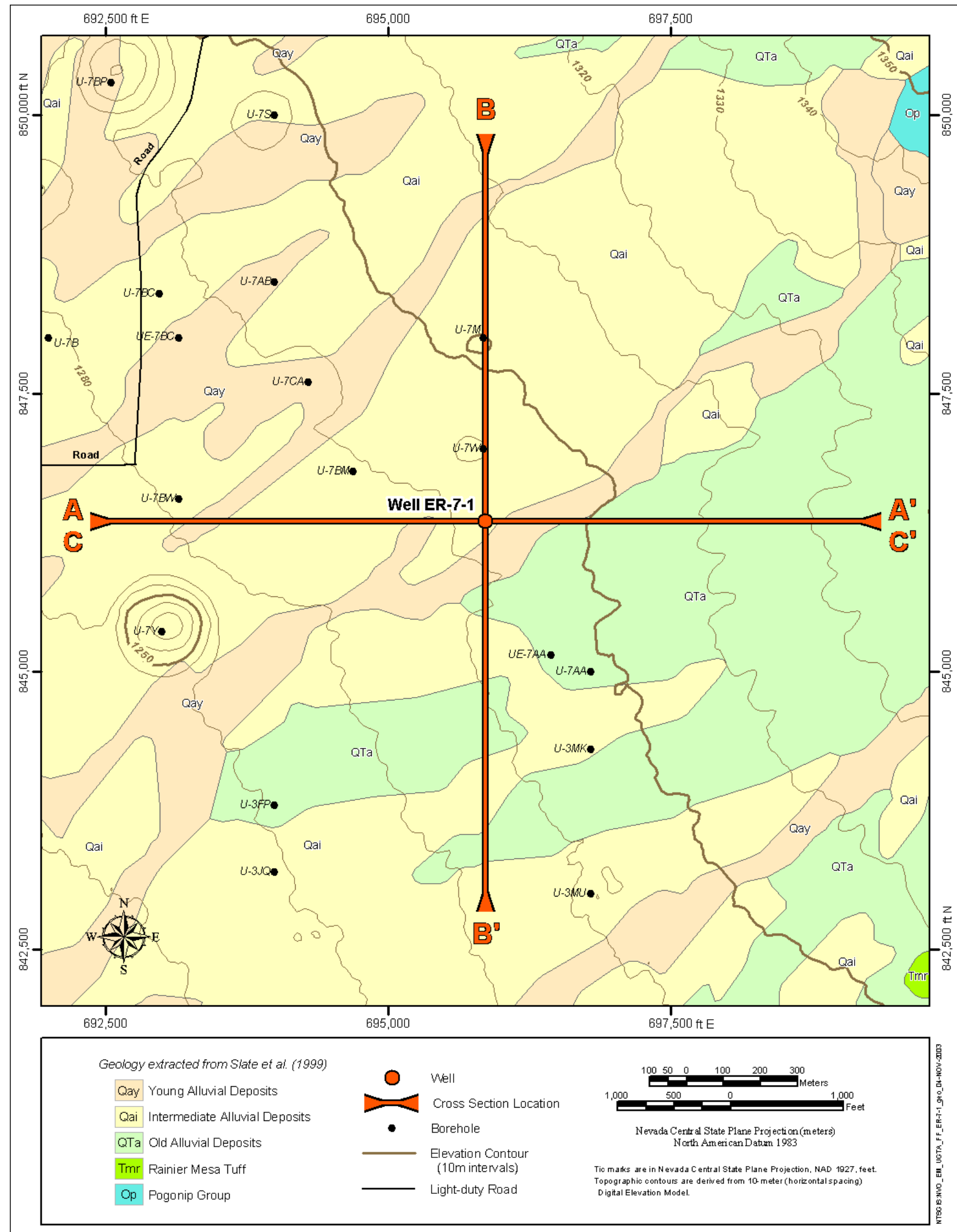

Figure 4-2

Surface Geologic Map of the Well ER-7-1 Site 
This page intentionally left blank. 
borehole penetrated over $244 \mathrm{~m}$ (800 ft) of Paleozoic-age sedimentary rocks. The stratigraphy and detailed lithology of the rocks encountered at Well ER-7-1 are very similar to those of nearby Emplacement Hole U-7ca (Drellack et al., 1986) and other nearby holes. The stratigraphy and lithology of Well ER-7-1 are illustrated in Figure 4-3.

\subsubsection{Stratigraphy and Structure}

Drilling of Well ER-7-1 began in Quaternary and Tertiary tuffaceous alluvial deposits that are $65.5 \mathrm{~m}$ $(215 \mathrm{ft})$ thick at the well site. The borehole then penetrated $62.5 \mathrm{~m}$ (205 ft) of mostly welded ashflow tuff assigned to the Rainier Mesa tuff, a unit of the Timber Mountain Group. Below the Timber Mountain Group rocks, the well penetrated $51.8 \mathrm{~m}$ (170 ft) of mostly vitric bedded and air-fall tuffs of the pre-Rainier Mesa, post-Wahmonie Canyon Tuffs, in turn underlain by the Wahmonie Tuff and Crater Flat Tuff, that have a combined thickness of $100.6 \mathrm{~m}(330 \mathrm{ft})$. Below these units, a thick sequence of bedded and nonwelded tuff units was encountered; these beds are assigned to the Tunnel Formation, older undifferentiated tuffs, and paleocolluvium. These mostly zeolitized units have a combined thickness of $449.7 \mathrm{~m}$ (770 ft). Below the Tertiary-age volcanic rocks and the paleocolluvium, the borehole penetrated a thick sequence of limestone of Cambrian age. These limestone units, not yet identified to stratigraphic unit, pending paleontological analysis, have a minimum (drilled) thickness of about $247 \mathrm{~m}$ (810 ft). Drilling was terminated in limestone at a depth of $762.0 \mathrm{~m}$ $(2,500 \mathrm{ft})$.

The relative position, extent, and thickness of the stratigraphic units near Well ER-7-1 are illustrated on the west-east and north-south cross sections in Figures 4-4 and 4-5, respectively. As shown on the west-east cross section (Figure 4-4), the well is located on a minor structural block bounded by two high-angle, north-south trending faults. The presence of the fault to the west of Well ER-7-1 was geologically inferred from drill-hole data, while the fault to the east was inferred mainly from gravity data (Drellack, 1986). The bedding dip of the Tertiary volcanic units and the upper surface of the underlying Paleozoic section is fairly shallow toward the west, as depicted in the west-east cross section (Figure 4-4). The westerly dip was determined from drill-hole data and by extrapolation from structure contour and isopach maps of the area (Drellack, 1994). Preliminary analysis of the Electric MicroImager $^{\circledR}$ (Enhanced Image, field print) also indicates a westerly dip direction. 
This page intentionally left blank. 


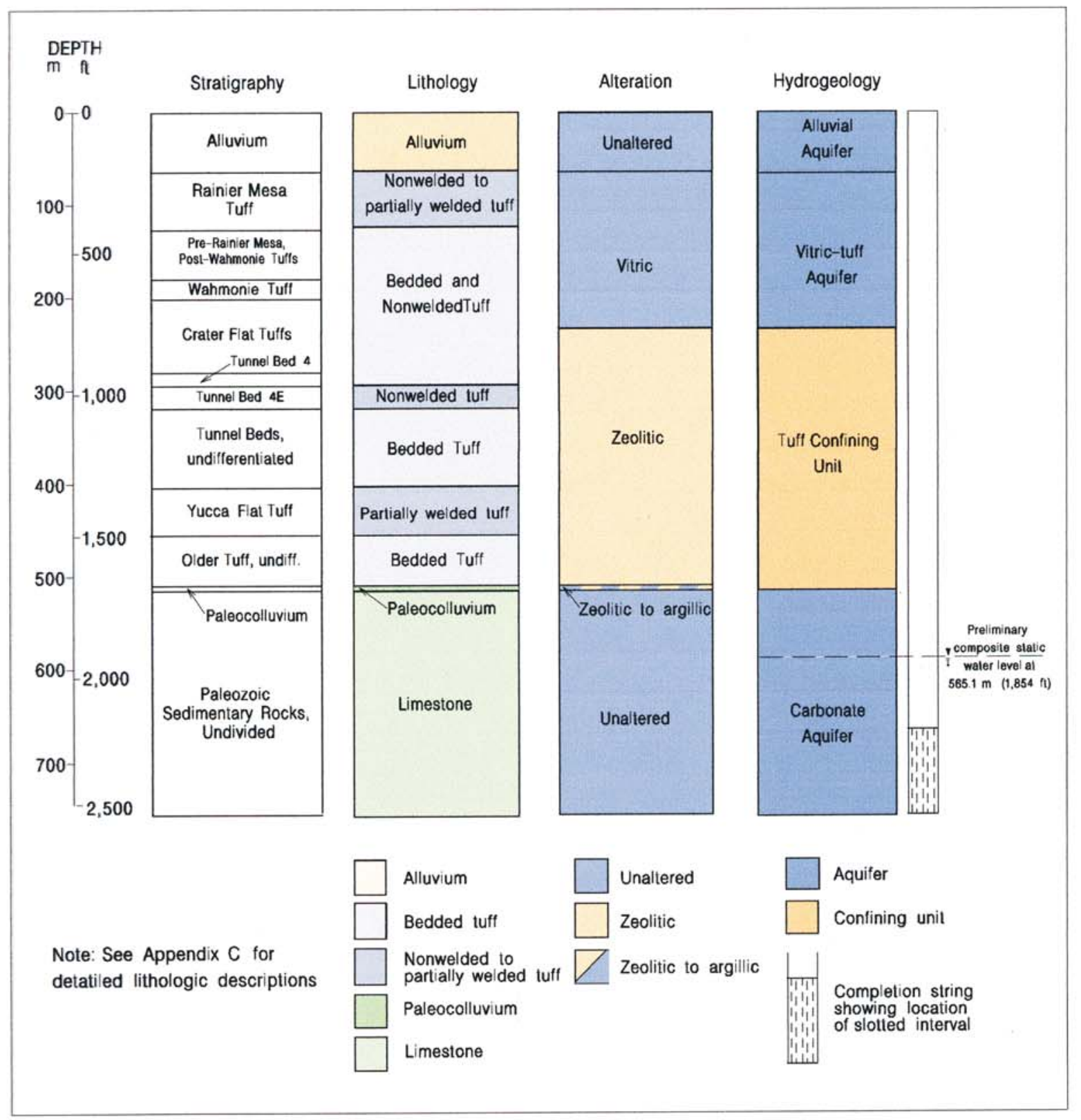

Figure 4-3

Geology and Hydrogeology of Well ER-7-1 
This page intentionally left blank. 


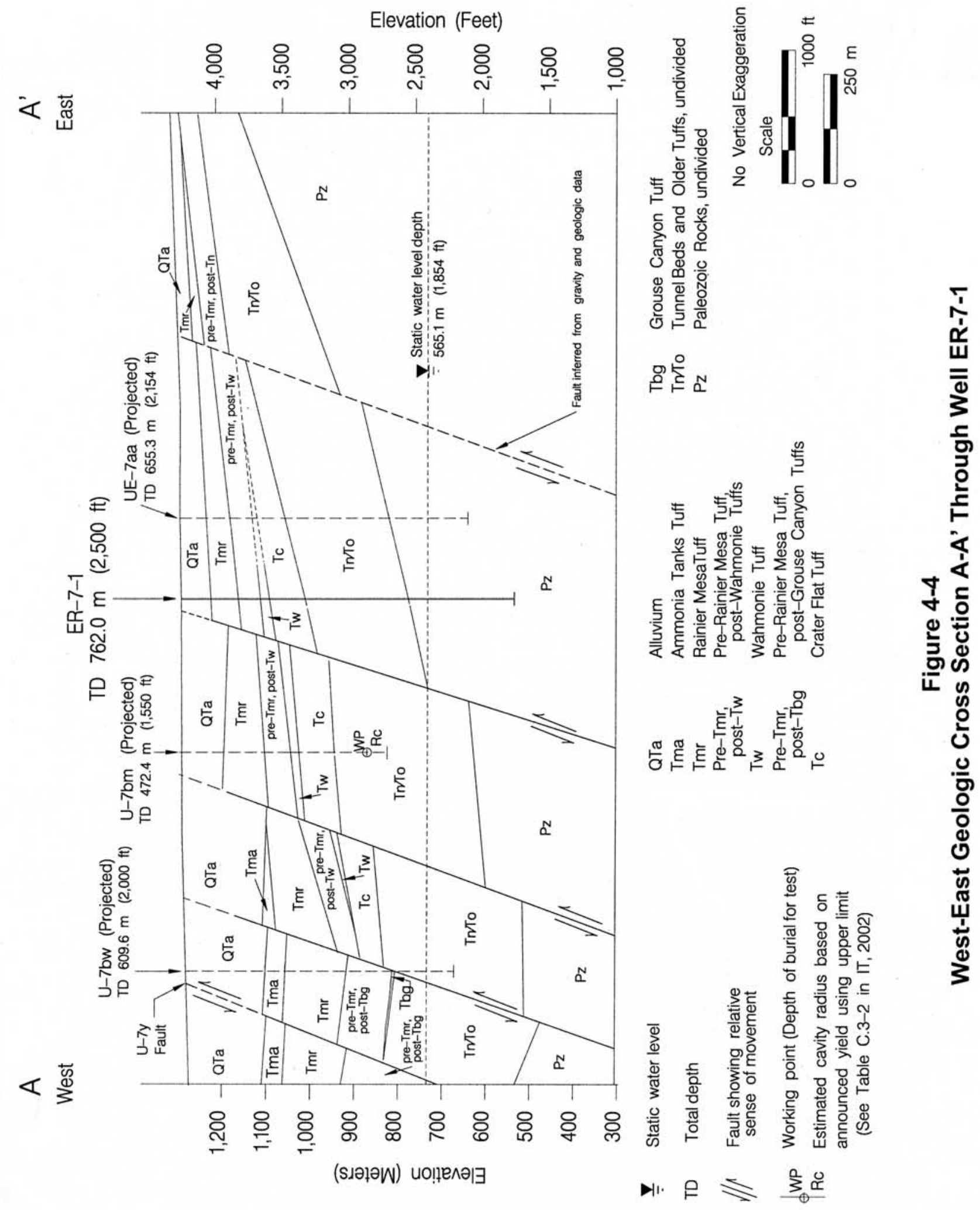




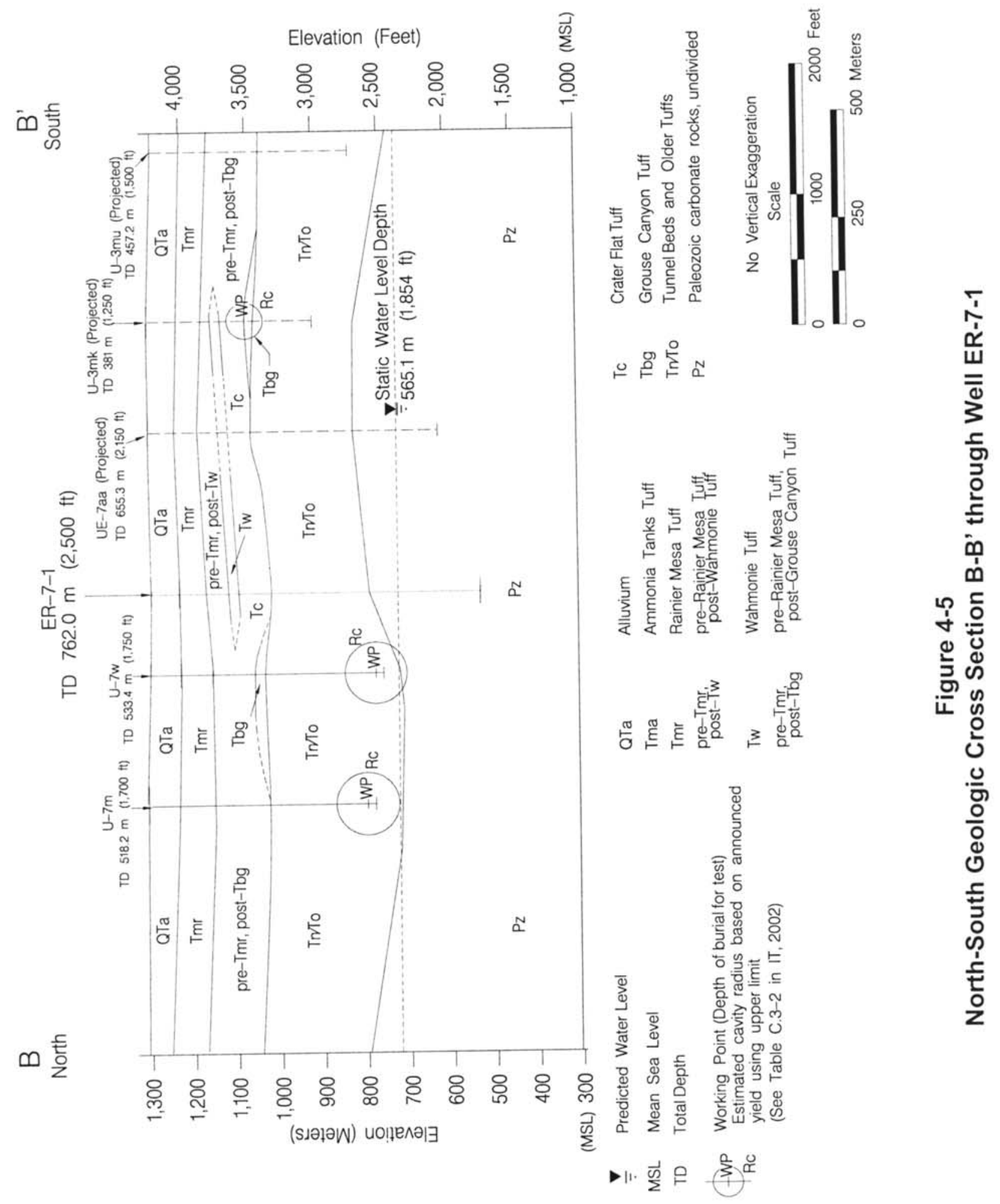




\subsubsection{Alteration}

Alteration has a significant effect on both the hydraulic character of volcanic rocks and on how radionuclides migrate through these rocks. The predominant type of mineralogic alteration observed in drill cuttings in each stratigraphic unit encountered in Well ER-7-1 is illustrated in Figure 4-3. The rocks below the $65.5-\mathrm{m}(215-\mathrm{ft})$ thick unaltered alluvium and above the depth of $228.6 \mathrm{~m}(750 \mathrm{ft})$ are also mostly unaltered (vitric), with lesser amounts of devitrified, silicic, and zeolitic alteration. Below the depth of $228.5 \mathrm{~m}$ ( $750 \mathrm{ft}$ ), the rest of the volcanic section is zeolitic. All rocks below $515.1 \mathrm{~m}$ $(1,690 \mathrm{ft})$ are unaltered Paleozoic-age sedimentary rocks consisting mostly of limestone.

\subsection{Predicted Versus Actual Geology}

The predicted geology for Well ER-7-1 (IT, 2002) was based on knowledge of geologic units that were encountered at nearby holes U-7ca, U-7w, U-7bm, and UE-7aa (Gonzales and Drellack, 1999; Drellack and Thompson, 1990). The depth and detailed lithology of the geologic units encountered in Well ER-7-1 were generally as predicted. A comparison of the predicted and the actual stratigraphy is provided in Figure 4-6.

\subsection{Hydrogeology}

The rocks of Well ER-7-1 can be subdivided into hydrogeologic units, as illustrated in Figure 4-3. A preliminary interpretation of the distribution of these units is shown in cross section on Figure 4-7.

The dominant saturated hydrogeologic unit in Well ER-7-1 is a carbonate aquifer, consisting mostly of limestone, and accounting for approximately 32 percent of the rocks penetrated by the well. Analysis of water production during drilling indicates that the carbonate aquifer rocks produced water at a rate of about 1,136 lpm (300 gpm) to as much as 1,893 lpm (500 gpm) during drilling below a depth of $695.3 \mathrm{~m}(2,281 \mathrm{ft})$. 


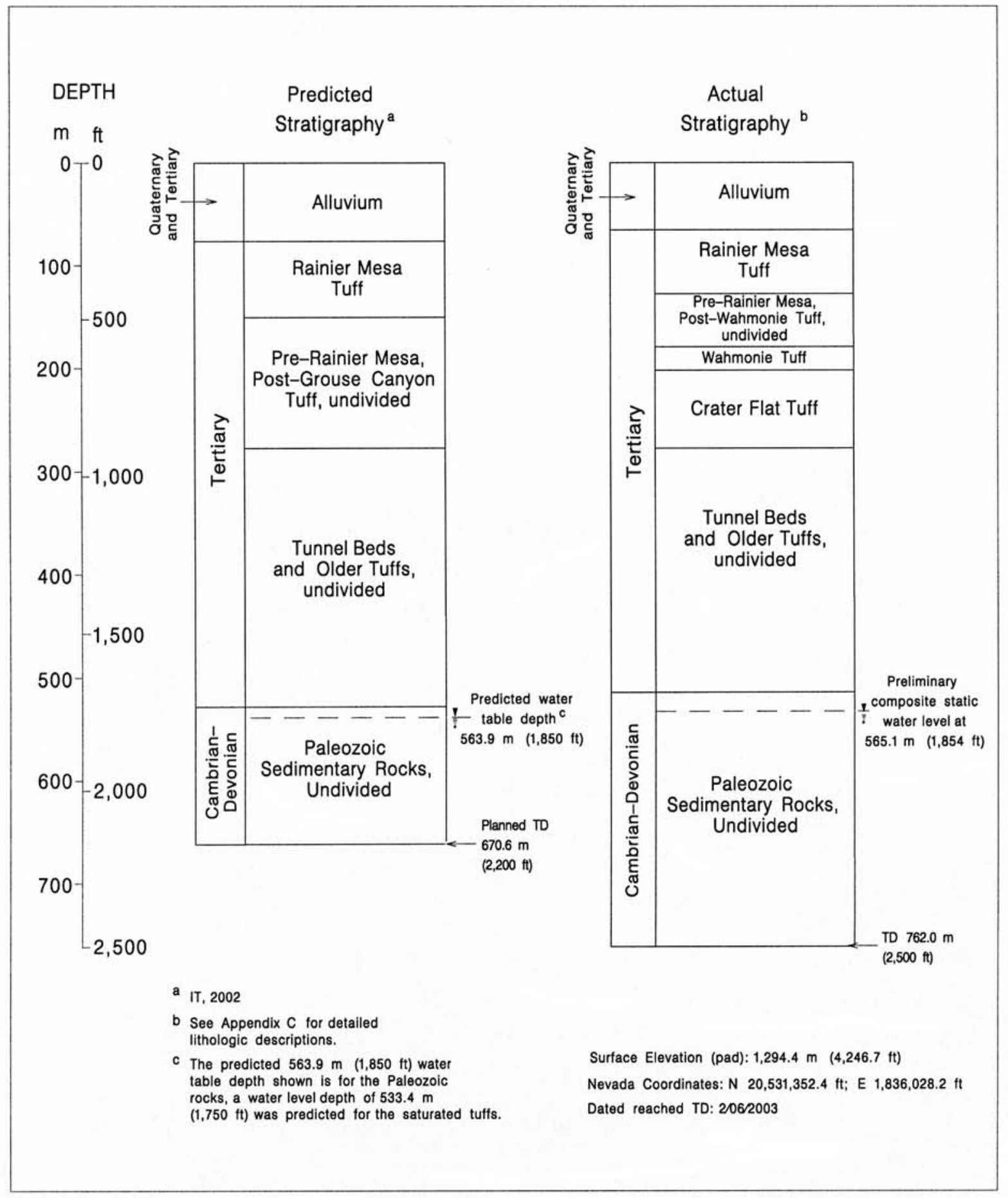

Figure 4-6

Predicted and Actual Stratigraphy at Well ER-7-1 


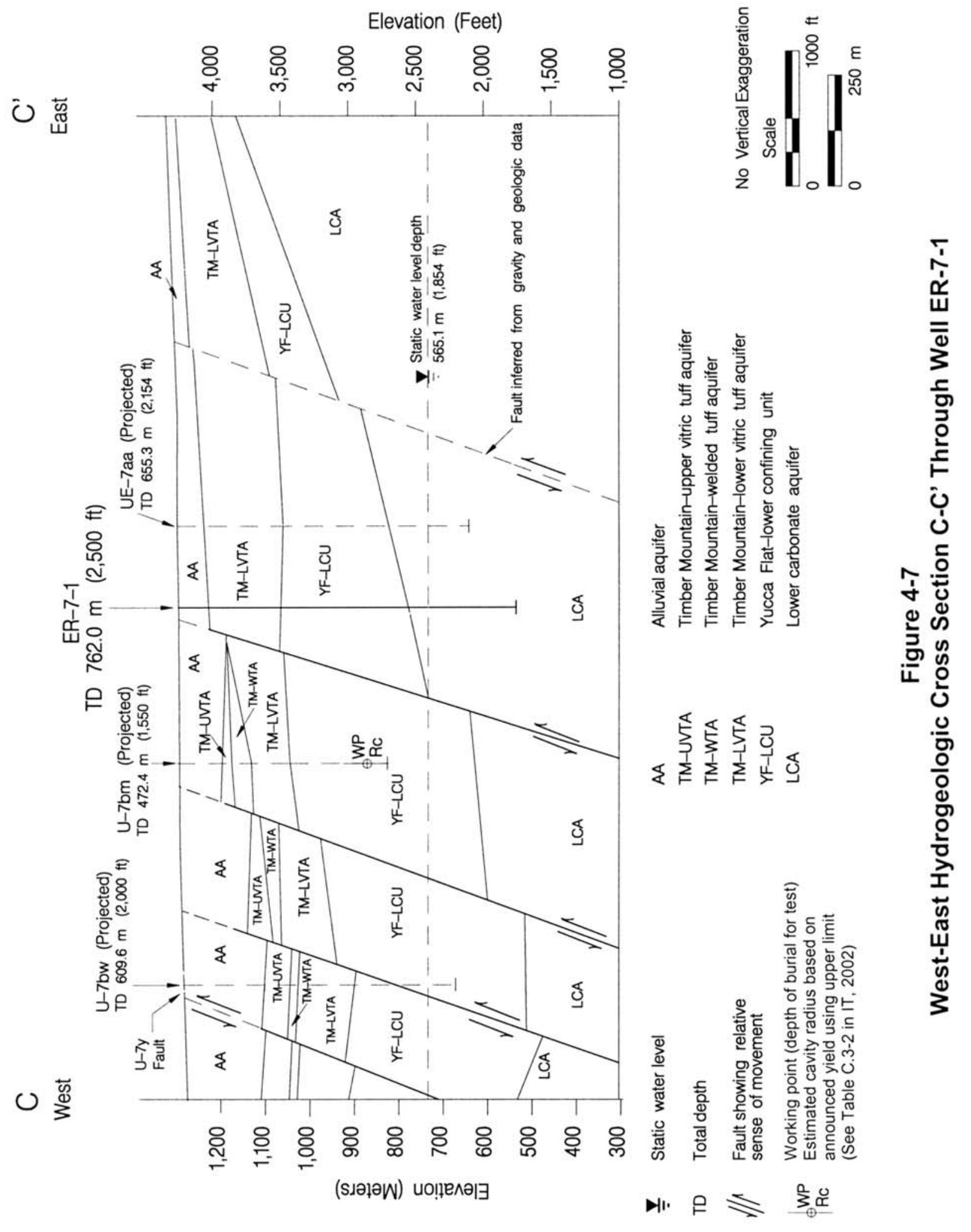


This page intentionally left blank. 


\subsection{Hydrology}

\subsection{Preliminary Water-Level Information}

Well ER-7-1 was drilled to provide additional hydraulic head data for northern Yucca Flat and to provide a well to help evaluate the regional carbonate aquifer down-gradient from an underground nuclear test which was conducted close to the carbonate aquifer. The elevation of the water table at ER-7-1 was projected to be approximately $760.5 \mathrm{~m}(2,495 \mathrm{ft})$ in the Tertiary-age volcanic units, and $730.0 \mathrm{~m}$ (2,395 ft) in the Paleozoic-age carbonate rocks (IT, 2002). Based on the pre-construction estimate of surface elevation at the site, depth to water was expected at approximately $533.4 \mathrm{~m}$ $(1,750 \mathrm{ft})$ (Tertiary-age volcanic units) and $563.9 \mathrm{~m}$ (1,850 ft) (Paleozoic-age carbonate rocks).

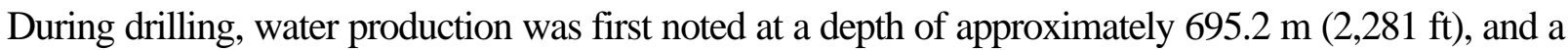
fluid depth of $565.1 \mathrm{~m}$ (1,854 ft) was obtained from a density neutron $\log$ run on February 7, 2003, before the completion string was installed.

\subsection{Water Production}

Water production was estimated during drilling of Well ER-7-1 on the basis of LiBr dilution data as measured by Shaw field personnel. Water production began at the depth of about $695.2 \mathrm{~m}(2,281 \mathrm{ft})$ within the Paleozoic carbonate rocks, and remained fairly steady to the TD of $762.0 \mathrm{~m}(2,500 \mathrm{ft})$ at the rate of 1,136 to $1,893 \mathrm{lpm}$ (300 to $500 \mathrm{gpm}$ ). Estimated water production rates are presented graphically in Appendix A-1.

\subsection{Preliminary Flow Meter Data}

Flow meter data, along with temperature, electrical conductivity (EC), and $\mathrm{pH}$ measurements, can be used to characterize borehole fluid variability, which may indicate inflow and outflow zones. Desert Research Institute (DRI) personnel tried to make measurements with their thermal flow meter (TFM) tool but, after running two different tools into the hole, only one data point at $579.1 \mathrm{~m}(1,900 \mathrm{ft})$ was acquired.

In addition, DRI ran a chemistry log, which included measurements of temperature, $\mathrm{EC}$, and $\mathrm{pH}$ in the fluid column, from 565.1 to $761.4 \mathrm{~m}$ (1,854 to 2,498 ft). Groundwater temperature gradually increased from the minimum reading of 41.0 degrees Celsius $\left({ }^{\circ} \mathrm{C}\right)\left(105.9\right.$ degrees Fahrenheit $\left.\left[{ }^{\circ} \mathrm{F}\right]\right)$ at the top of the fluid column to the depth of approximately $698.0 \mathrm{~m}(2,290 \mathrm{ft})$, where the maximum recorded temperature in the borehole was measured at $45.5^{\circ} \mathrm{C}\left(114^{\circ} \mathrm{F}\right)$. Below this depth, which 
coincides with the location of maximum water production in the borehole, the fluid temperature decreased slightly. The plot of the chemistry log data is reproduced in Appendix D.

\subsection{Preliminary Groundwater Characterization Sample}

Following geophysical logging, DRI collected a preliminary groundwater characterization sample at the depth of $698.0 \mathrm{~m}$ (2,290 ft) in the open borehole. Analytical data from this initial sample, collected before formal well development, will provide a basis for comparison with future groundwater chemistry data. 


\subsection{Precompletion and Open-Hole Development}

The only precompletion development conducted in Well ER-7-1 consisted of circulating fluid for 30 minutes to clean the borehole and using two compressors to blow water out of the hole. This process was conducted immediately after TD was reached and prior to geophysical logging. 
This page intentionally left blank.

6-2 


\subsection{Well Completion}

\subsection{Introduction}

Well completion refers to the installation in a borehole of a string of pipe or casing that is slotted or screened at one or more locations along its length. The completion process also typically includes emplacement of backfill materials such as cement, sand, or gravel around the casing, to isolate selected intervals, though in some wells the completion string is left in an open hole. The casing serves as a conduit for insertion of a pump in the well, for inserting devices for measuring fluid level, and for sampling, so that accurate potentiometric and water chemistry data can be collected from known portions of the borehole.

The proposed well completion design for Well ER-7-1, as presented in the Yucca Flat drilling criteria document (IT, 2002) is described in Section 7.2.1. The actual well completion, designed on the basis of the hydrogeology encountered in the borehole, is presented in Section 7.2.2.

Completion activities at Well ER-7-1 took place on February 9 and 10, 2003, after geophysical logging operations were concluded. Figure 7-1 is a schematic of the final completion design for Well ER-7-1, Figure 7-2 depicts a plan view and profile of the wellhead surface completion, and Table 7-1 is a construction summary for the well. Data for this section were obtained from daily operations and activity reports, casing records, and cementing records provided by the BN Drilling Department. Shaw's well data report (Shaw, 2003) was also consulted for preparation of this section.

\subsection{Well Completion Design}

The final completion design differs slightly from the proposed design, as described in the following paragraphs

\subsubsection{Proposed Completion Design}

Well ER-7-1 was designed to provide geologic information and groundwater production data from the LCA, and to serve as a water-level monitoring point within the Yucca Flat lower confining unit (YF-LCU), if the unit were saturated. It was planned to install a production string consisting of slotted, 7e -in. carbon-steel casing, open, through a gravel-pack, to water-producing zones in the LCA. If groundwater were present in the YF-LCU, access to it would be accomplished by installing a $2 f$-in. piezometer string, slotted within a 15.2-m (50-ft) interval of the YF-LCU. If a surface casing had been installed to stabilize the upper part of the borehole during drilling, the piezometer 


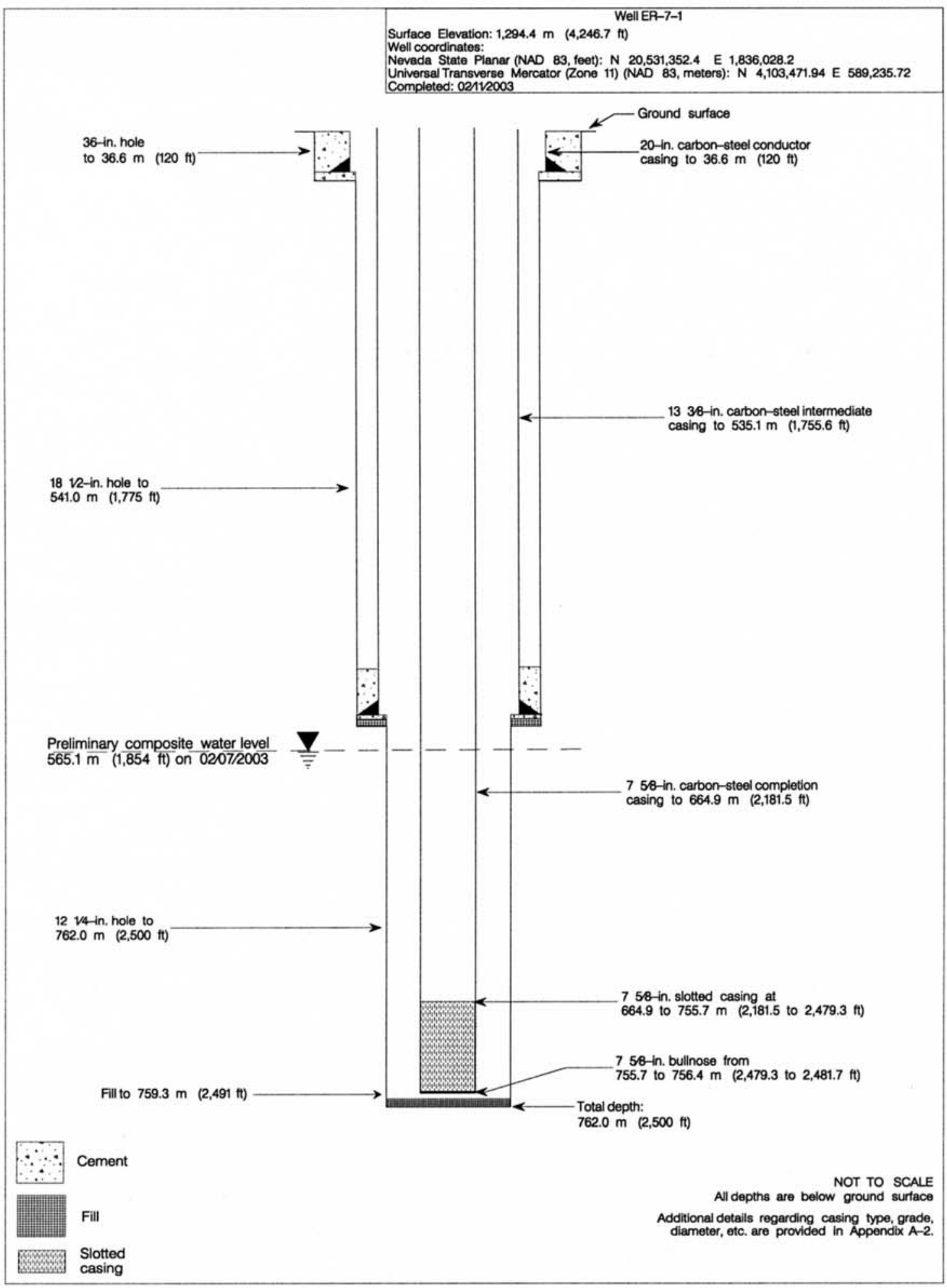

Figure 7-1

As-Built Completion Schematic for Well ER-7-1 


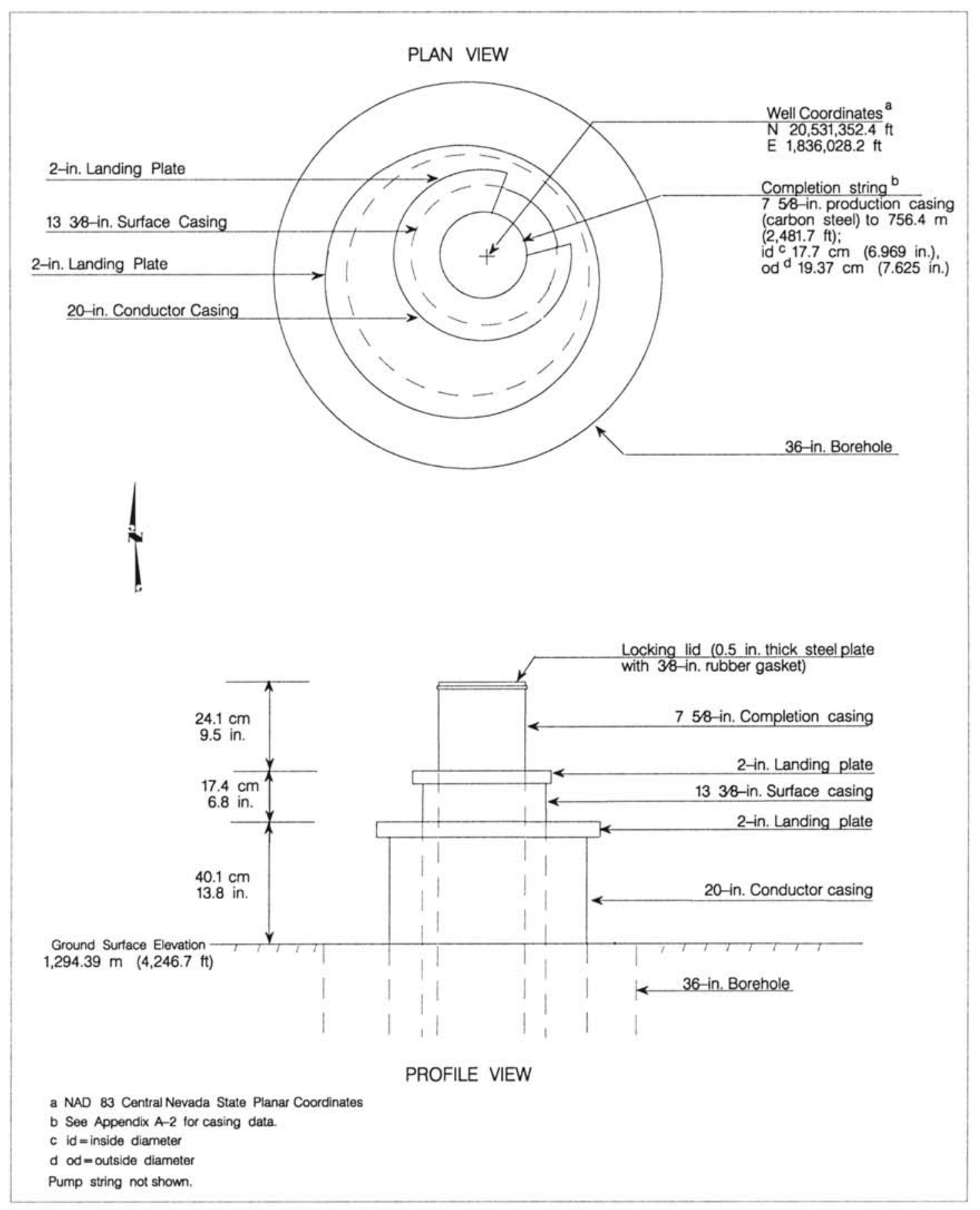

Figure 7-2

Wellhead Diagram for Well ER-7-1 
Table 7-1

Well ER-7-1 Completion String Construction Summary

\begin{tabular}{|c|c|c|c|c|}
\hline Casing Type & \multicolumn{2}{|c|}{$\begin{array}{c}\text { Configuration } \\
\text { meters (feet) }\end{array}$} & Cement & Sand/Gravel \\
\hline \multirow{3}{*}{$\begin{array}{l}7 e \text {-in. carbon- } \\
\text { steel production } \\
\text { casing }\end{array}$} & $\begin{array}{c}0 \text { to } 664.9 \\
(0 \text { to } 2,181.5)\end{array}$ & Blank & \multirow{3}{*}{ None } & \multirow{3}{*}{ None } \\
\hline & $\begin{array}{c}664.9 \text { to } 755.7 \\
(2,181.5 \text { to } 2,479.3)\end{array}$ & $\begin{array}{l}7 \text { consecutive } \\
\text { slotted joints }\end{array}$ & & \\
\hline & $\begin{array}{c}755.7 \text { to } 756.4 \\
(2,479.3 \text { to } 2,481.7)\end{array}$ & $\begin{array}{c}\text { Blank and bull- } \\
\text { nosed }\end{array}$ & & \\
\hline
\end{tabular}

would be installed adjacent to the surface casing, in the borehole annulus, when the surface casing was installed. If the surface casing were not required, the piezometer would be placed in the annulus outside the production casing, and would be gravel-packed and cemented in place at the time the production casing was backfilled.

\subsubsection{As-Built Completion Design}

The design of the Well ER-7-1 completion was determined through consultation with members of the UGTA Technical Working Group, on the basis of evaluation of data such as lithology and water production, drilling data, and data from various geophysical logs. The as-built completion design provides access to the LCA via a 7 e -in. production casing.

The $7 \mathrm{e}$-in. carbon-steel casing was set at $756.4 \mathrm{~m}(2,481.7 \mathrm{ft})$, and is slotted in the interval 665.9 to $755.7 \mathrm{~m}$ (2,181.5 to $2,479.3 \mathrm{ft})$. The bottom seven joints are slotted, and the lowest joint is bullnosed. The openings in each slotted casing joint are $0.15 \mathrm{~cm}(0.0624 \mathrm{in}$.) wide and $5.1 \mathrm{~cm}(2.0 \mathrm{in}$.) long. The slots are arranged in rows of 18, with rows staggered 10 degrees on 7.62-cm (3-in.) centers. The production casing was installed in the open borehole, and no piezometer string was installed.

\subsubsection{Rationale for Differences between Planned and Actual Well Design}

The initial planned well design was based on the expectation that groundwater would be present in the YF-LCU and in the LCA. The inability to determine the static water table in the YF-LCU made the establishment of a piezometer in the YF-LCU unnecessary. Likewise, because no other 
water-producing zones were to be isolated in Well ER-7-1, and because the slotted interval is well below the water table, gravel-packing and cementing of the production casing were not necessary.

\subsection{Well Completion Method}

Well completion activities began on February 9, 2003, when the casing crew landed the 7e -in. production casing at $756.4 \mathrm{~m}(2,481.7 \mathrm{ft})$. No gravel pack or cement was used with this casing string, which remains open below the $13 \mathrm{~d}$-in. intermediate casing, set at the depth of $535.1 \mathrm{~m}(1,755.6 \mathrm{ft})$ (Figure 7-1). All well construction materials were inspected according to relevant procedures. Standard decontamination procedures were employed to prevent the introduction of contaminants into the well.

The drill rig was released after the 7 e -in. production casing was emplaced. Hydrologic testing was planned as a separate effort, so a pump was not installed in the well and no well-development or pumping tests were conducted immediately after completion. 
This page intentionally left blank. 


\subsection{Actual versus Planned Costs and Scheduling}

The original BN cost model developed for Well ER-7-1 was based on drilling to a TD of $670.6 \mathrm{~m}$ $(2,200 \mathrm{ft})$. However, when no groundwater had been encountered at the planned TD depth, the decision was made to deepen the borehole, and the baseline model was changed to accommodate the new planned TD. This new cost model is based on the TD of $762.0 \mathrm{~m}(2,500 \mathrm{ft})$.

The new drilling program baseline projected that it would require 17 days to accomplish drilling of the surface and main holes, logging, and completion for the well, assuming the conductor hole had already been constructed by BN. The actual time spent to drill the hole and install the completion string in Well ER-7-1 was 16 days. Installation of the production string took one day less time than anticipated. A graphical comparison (by day) of planned and actual well-construction activities is presented in Figure 8-1.

The cost analysis for Well ER-7-1 begins with construction of the conductor hole by BN and the cost of mobilizing the UDI drill rig to the Well ER-7-1 site. The cost of building roads, the drill pad, and sumps is not included, and the cost of well-site support by Shaw is also not included. The total construction cost for Well ER-7-1 includes all drilling costs: charges by the drilling subcontractor; charges by other support subcontractors (including compressor services, drilling fluids, bits, casing services, down-hole tools, and geophysical logging); and charges by BN for mobilization and demobilization of equipment, partial construction of the conductor hole, cementing services, radiation technicians, inspection services, and geotechnical consultation.

The total planned cost for construction Well ER-7-1, based on the new baseline developed due to the deeper than anticipated groundwater, was $\$ 1,458,602$. The actual cost was $\$ 1,372,470$, or 5.9 percent less than the planned cost. Figure 8-2 presents a comparison of the planned (new baseline) and actual costs, by day, for drilling and completing Well ER-7-1. 


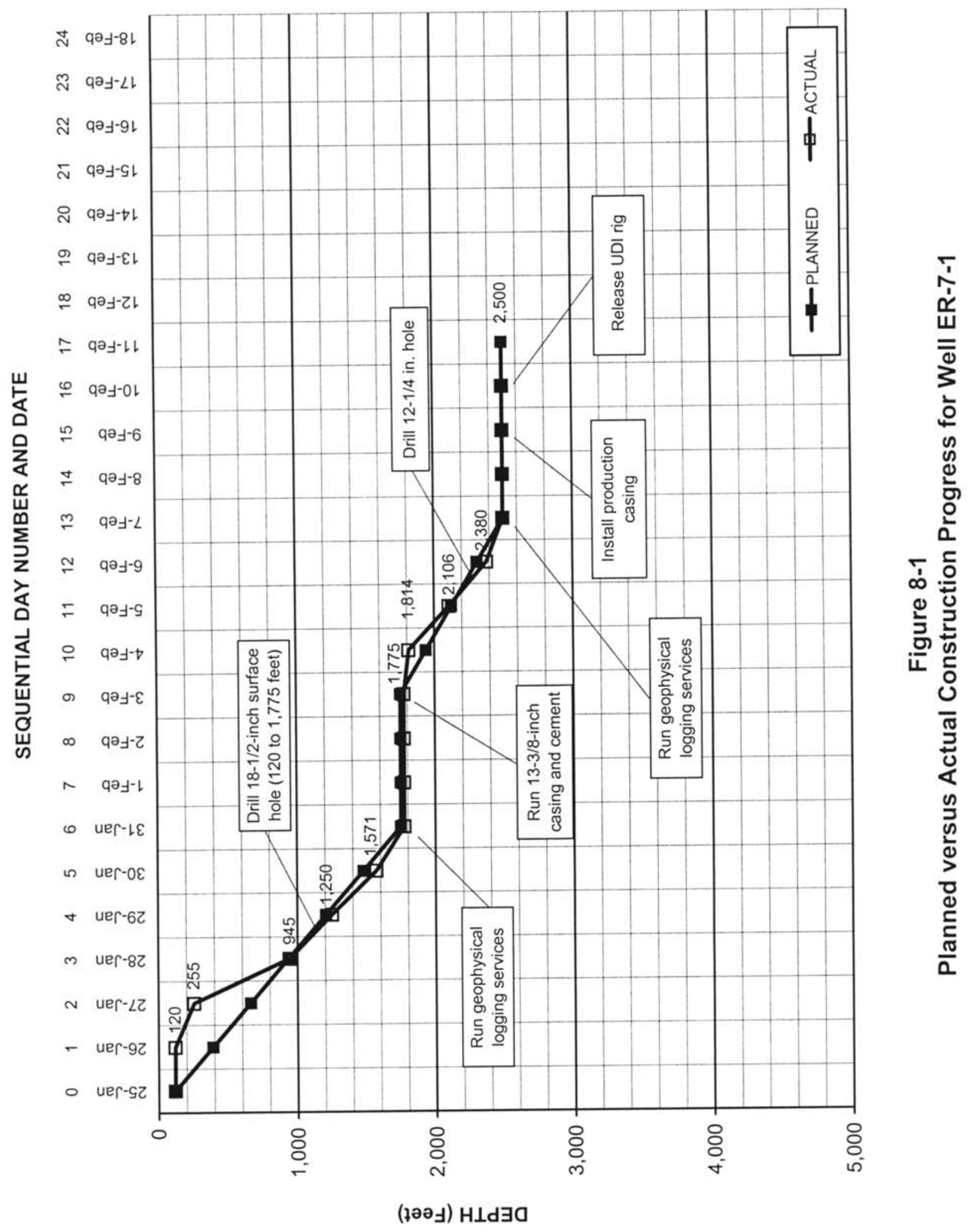




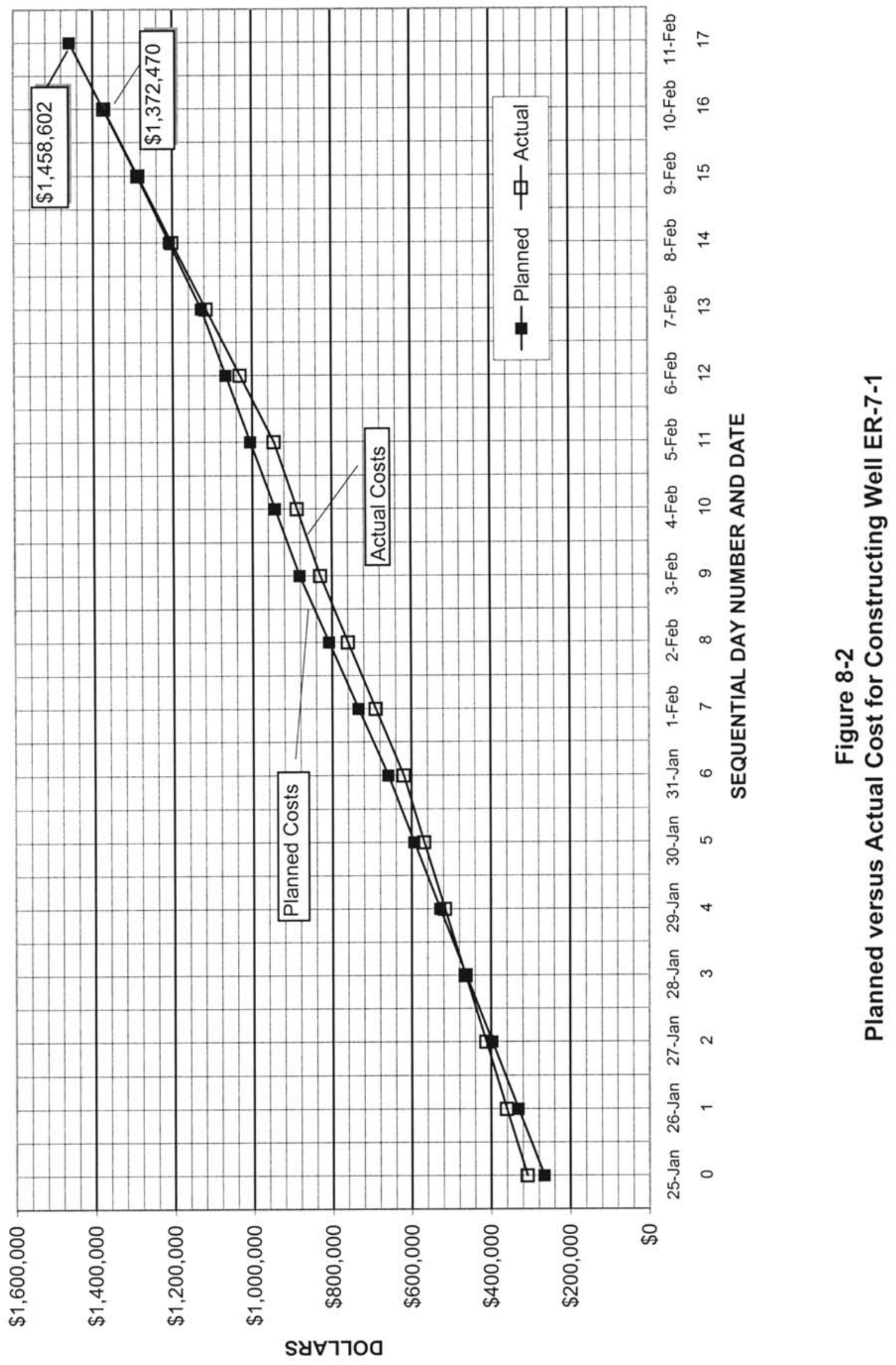


This page intentionally left blank. 


\subsection{Summary, Recommendations, and Lessons Learned}

\subsection{Summary}

Drilling activities at Well ER-7-1 commenced on January 27, 2003, and concluded on

February 7, 2003, when the TD of $762.0 \mathrm{~m}$ (2,500 ft) was reached. After geophysical logging, the completion string was installed on February 9, 2003. Crews worked on a 24-hours-per-day, 7-daysper-week schedule for most of the operation. Sixteen working days were expended to drill the surface and main holes, conduct geophysical logging, install the completion string, and rig-down. The only problems encountered during construction of Well ER-7-1 were delays during drilling to address issues with RWPs and monitoring of crew bioassays.

No radionuclides above background were encountered in the groundwater produced from Well ER-7-1. The fluid level within the Paleozoic rocks, based on a neutron density log run on February 7, 2003, was measured at an approximate depth of $565.1 \mathrm{~m}(1,854.0 \mathrm{ft})$ below ground surface.

Composite drill cuttings were collected every $3 \mathrm{~m}$ (10 ft) from $36.6 \mathrm{~m}$ (120 ft) to TD. Sixty-two sidewall samples were collected in the interval 85.3 to $754.1 \mathrm{~m}$ (280.0 to 2,474.0 ft). Geophysical logging was conducted in the upper part of the hole before installation of the surface casing, and in the lower part of the hole before installation of the completion string. Some of these logs were used to aid in construction of the well, while others help to verify the geology and determine the hydrologic characteristics of the rocks.

A single completion string with one slotted interval was installed in Well ER-7-1. A string of 7e -in. carbon-steel casing was landed at $756.4 \mathrm{~m}(2,481.7 \mathrm{ft})$. No backfill materials were placed around the completion string, and the borehole remains open below the surface casing. The open interval in the $7 \mathrm{e}$-in. casing extends from 664.1 to $746.4 \mathrm{~m}$ (2,178.7 to 2,481.7 ft). This interval is open to carbonate sedimentary rocks of Paleozoic age.

\subsection{Recommendations}

The planned pump installation, well development, groundwater sampling, and hydrologic testing must be conducted at Well ER-7-1 to accomplish the remaining objectives for this well-construction effort. 
A complete computer analysis of the Electric Micro Imager ${ }^{\circledast}$ (EMI) log data from Well ER-7-1 is planned to determine dip directions and fracture characteristics.

Twenty-seven of the sidewall core samples taken in Well ER-7-1 were from the limestone of the LCA. It may be possible to obtain valuable data on the fracture filling and other fracture characteristics for the LCA in this area using these samples.

After all the planned Yucca Flat hydrogeologic investigation wells are drilled, geologic and hydrologic data must be evaluated, and interpretations of the area hydrogeology updated for insertion into the UGTA hydrologic model. This process, along with the analysis of the updated model, will enhance the understanding of groundwater flow direction, and velocity in the Yucca Flat region.

\subsection{Lessons Learned}

On two different occasions, drilling operations were temporarily suspended to address issues with RWPs. In the future, RWP issues should be addressed prior to drilling.

During logging activities, the percussion core tool and the thermal flow tool failed to operate properly. Research to identify and correct the cause of the malfunctioning tools is recommended. 


\subsection{References}

Bangerter, R. M., National Nuclear Security Administration Nevada Site Office, 2002. Verbal communication to P. K. Ortego, Bechtel Nevada. Subject: Lining of Sumps at the ER-7-1 Site. BN Record of Verbal Communication Number RVC-03-0002. December 9, 2002,

Bechtel Nevada, 2001. Multiple Well Sites on the Nevada Test Site (NTS) and the Nellis Air Force Range (NAFR) and Bureau of Land Management (BLM) Lands Health and Safety Plan (HASP). January 2001. Las Vegas, Nevada.

Bechtel Nevada, 2002. Field Activity Work Package - Main Hole Construction of Underground Test Area (UGTA) Well ER-7-1 in Yucca Flat. FAWP D-001-001-03. Las Vegas, Nevada.

BN, see Bechtel Nevada.

Byers, F. M., Jr., and H. Barnes, 1967. “Geologic Map of the Paiute Ridge Quadrangle, Nye and Lincoln Counties, Nevada.” U.S. Geological Survey, Geologic Quadrangle Map GQ 577, scale 1:24,000. Washington, D.C.

Colton, R. B., and E. J. McKay, 1966. "Geologic Map of the Yucca Flat Quadrangle, Nye and Lincoln Counties, Nevada.” U.S. Geologic Survey, Geologic Quadrangle Map GQ 582, scale 1:24,000. Washington, D.C.

DOE/NV, see U.S. Department of Energy.

Drellack, S. L., Jr., 1986. Written communication. Subject: “Geologic Site Characterization Report for Emplacement Hole U-7ca.” Fenix \& Scisson, Inc., Las Vegas, Nevada.

Drellack, S. L., Jr., 1994. Written communication. Subject: "Subsurface Geologic Maps of Southern Yucca Flat, Nevada.” Memorandum TSP:DGP:024:95 to Distribution. Raytheon Services Nevada, Las Vegas, Nevada.

Drellack, S. L., Jr., and P. H. Thompson, 1990. Selected Geologic Subsurface Maps of LANL Use Areas of Yucca Flat, Nevada Test Site. DOE/NV/10322-40. Fenix \& Scisson of Nevada Geologic Report. Las Vegas, Nevada.

Drellack, S. L., J. L. Gonzales and A. P. Cavazos, 1986. Lithology and stratigraphy of Drill Holes Completed During 1985 in LANL Use Areas of Yucca Flat, Nevada Test Site (Volume VII). Fenix and Scisson Inc. Report DOE/NV/10322-9. Mercury, Nevada.

Gonzales, J. L., S. L. Drellack, and M. J. Townsend,1998. Written communication. Subject: "Descriptive Narrative for the Hydrogeologic Model of the Yucca Flat Corrective Action Unit." Bechtel Nevada, Las Vegas, Nevada. 
Gonzales, J. L., and S. L. Drellack, 1999. Written communication. Subject: "Addendum to the Descriptive Narrative for the Hydrogeologic Model of the Yucca Flat Corrective Action Unit: Northern Extension.” Bechtel Nevada, Las Vegas, Nevada.

IT, see IT Corporation.

IT Corporation, 2002. Yucca Flat Hydrogeologic Investigation, Well Drilling and Completion Criteria. ITLV/13052--164. Las Vegas, Nevada.

Shaw Environmental, Inc., 2003. Written communication prepared for U.S. Department of Energy. Subject: "Yucca Flat ER-7-1 Well Data Report." May 2003. Las Vegas, Nevada.

Slate, J. L., M. E. Berry, P. D., Rowley, C. J. Fridrich, K. S. Morgan, J. B. Workman, O. D. Young, G. L. Dixon, V. S. Williams, E. H. McKee, D. A. Ponce, T. G. Hildenbrand, WC Swadley, S. C. Lundstrom, E. B. Ekren, R. G. Warren, J. C. Cole, R. J. Fleck, M. A. Lanphere, D. A. Sawyer, S. A. Minor, D. J. Grunwald, R. J. Laczniak, C. M. Menges, J. C. Yount, and A. S. Jayko, 1999. Digital Geologic Map of the Nevada Test Site and Vicinity, Nye, Lincoln, and Clark Counties, Nevada, and Inyo County, California. U.S. Geological Survey Open-File Report 99-554-A.

U.S. Department of Energy, Nevada Operations Office, 1996. Underground Test Area Subproject Work Management Plan, Rev. 1. DOE/NV--343. Las Vegas, Nevada.

U.S. Department of Energy, Nevada Operations Office, 2000. Corrective Action Investigation Plan for Corrective Action Unit 97: Yucca Flat/Climax Mine, DOE/NV--659. Las Vegas, NV.

U.S. Department of Energy, Nevada Operations Office, 2002. "Fluid Management Plan for the Underground Test Area Project." DOE/NV-370, Rev. 3. In: Underground Test Area Subproject Waste Management Plan, Rev. 2. Las Vegas, Nevada.

WoldeGabriel, G., 2003. Written communication. Email to S. L. Drellack, Bechtel Nevada. Subject: "Preliminary Geological Characterization, ER-7-1 Site, Yucca Flat." August 8, 2003. Los Alamos National Laboratory, Los Alamos, NM.

Wurtz, J., 2003. Written communication. Email to S. L. Drellack, Bechtel Nevada. Subject: "ER-7-1 Analytical Data [groundwater sample]." September 5, 2003. Shaw Environmental and Infrastructure, Las Vegas, NV.

Wycoff, R. C., U.S. Department of Energy, National Nuclear Security Administration, Nevada Operations Office. 2003. Letter to P. J. Liebendorfer (Nevada Division of Environmental Protection) entitled, "Well-Site Fluid Management Strategy, DOE NNSA/NV, Yucca Flat Drilling Program, Nevada Test Site, Well ER-7-1 Corrective Action Unit \#97, Yucca Flat/Climax Mine." Las Vegas, Nevada. 


\section{Appendix A \\ Drilling Data}

A-1 Drilling Parameter Log for Well ER-7-1

A-2 Casing Data for Well ER-7-1

A-3 Well ER-7-1 Drilling Fluids and Cement Composition 


\section{Appendix A-1 \\ Drilling Parameter Log for Well ER-7-1}




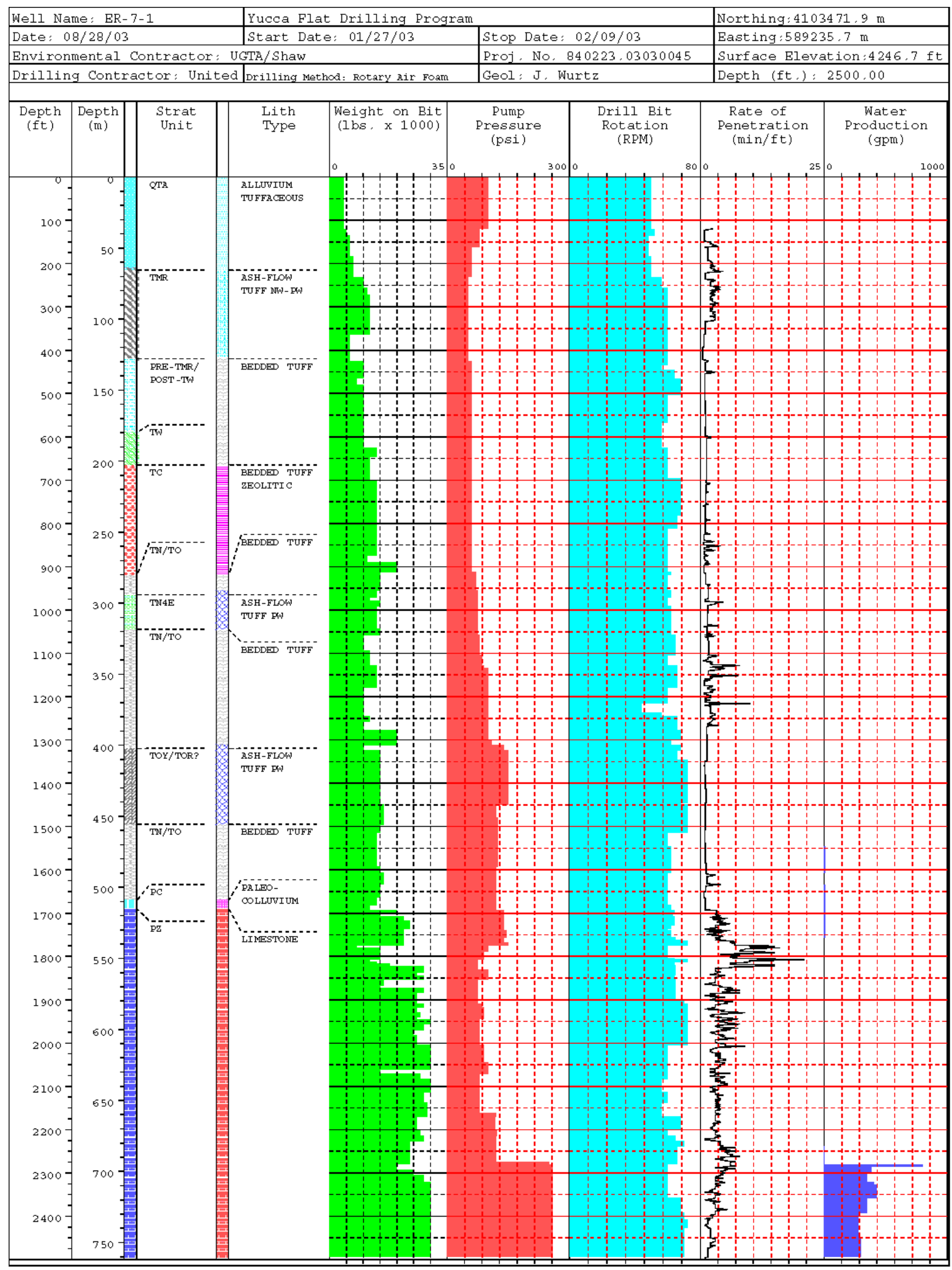


This page intentionally left blank.

A-1-2 
Appendix A-2

Casing Data for Well ER-7-1 
Table A-2

Casing Data for Well ER-7-1

\begin{tabular}{|c|c|c|c|c|c|c|c|}
\hline Casing & $\begin{array}{l}\text { Depth Interval } \\
\text { meters } \\
\text { (feet) }\end{array}$ & Type & Grade & $\begin{array}{l}\text { Outside } \\
\text { Diameter } \\
\text { centimeters } \\
\text { (inches) }\end{array}$ & $\begin{array}{c}\text { Inside } \\
\text { Diameter } \\
\text { centimeters } \\
\text { (inches) }\end{array}$ & $\begin{array}{c}\text { Wall } \\
\text { Thickness } \\
\text { centimeters } \\
\text { (inches) }\end{array}$ & $\begin{array}{l}\text { Weight } \\
\text { per foot } \\
\text { (pounds) }\end{array}$ \\
\hline $\begin{array}{l}\text { Conductor } \\
\text { Casing }\end{array}$ & $\begin{array}{c}0 \text { to } 36.6 \\
(0 \text { to } 120.0)\end{array}$ & Carbon steel & $\mathrm{N} / \mathrm{A}$ & $\begin{array}{l}50.5 \\
(20.0)\end{array}$ & $\begin{array}{c}48.6 \\
(19.124)\end{array}$ & $\begin{array}{l}1.113 \\
(0.438)\end{array}$ & 94 \\
\hline Surface Casing & $\begin{array}{c}0 \text { to } 338.5 \\
(0 \text { to } 1,110.5)\end{array}$ & Carbon steel & J55 & $\begin{array}{c}33.97 \\
(13.375)\end{array}$ & $\begin{array}{l}31.788 \\
(12.515)\end{array}$ & $\begin{array}{l}1.092 \\
(0.430)\end{array}$ & 61 \\
\hline Surface Casing & $\begin{array}{c}338.5 \text { to } 535.1 \\
(1,110.5 \text { to } 1,755.6)\end{array}$ & Carbon steel & J55 & $\begin{array}{c}33.97 \\
(13.375)\end{array}$ & $\begin{array}{c}32.04 \\
(12.615)\end{array}$ & $\begin{array}{l}0.965 \\
(0.380)\end{array}$ & 54.5 \\
\hline $\begin{array}{l}\text { Completion } \\
\text { Casing }\end{array}$ & $\begin{array}{c}0 \text { to } 756.4 \\
\text { (0 to } 2,481.65)\end{array}$ & Carbon steel & N80 & $\begin{array}{l}19.37 \\
(7.625)\end{array}$ & $\begin{array}{l}17.701 \\
(6.969)\end{array}$ & $\begin{array}{c}0.833 \\
(0.328)\end{array}$ & 26.4 \\
\hline
\end{tabular}


This page intentionally left blank.

A-2-2 
Appendix A-3

Well ER-7-1 Drilling Fluids and Cement Composition 
Table A-3-1

Well ER-7-1 Drilling Fluids

\begin{tabular}{|c|c|}
\hline Typical Air-Foam Mix ${ }^{a}$ & Typical Air-Foam/Polymer Mix ${ }^{\text {a }}$ \\
\hline $\begin{array}{c}56.8 \text { liters (15 gallons) Geofoam }{ }^{\circledR b} \\
\text { per } \\
7,949 \text { liters ( } 50 \text { barrels) water }\end{array}$ & $\begin{array}{c}132.5 \text { liters (35 gallons) Geofoam }{ }^{\circledR} \\
\text { and } \\
7.6 \text { liters ( } 2 \text { gallons) LP70 }{ }^{\circledR \mathrm{b}} \\
\text { per } \\
7,949 \text { liters ( } 50 \text { barrels) water }\end{array}$ \\
\hline
\end{tabular}

a An air-foam ("soap") mix was used as the drilling fluid in Well ER-7-1. Polymer was added to the air-foam mix below $670.6 \mathrm{~m}(2,200.0 \mathrm{ft})$.

b Geofoam ${ }^{\circledR}$ foaming agent and LP70 $1^{\circledR}$ polymer additive are products of Geo Drilling Fluids, Inc.

NOTES:

1. All water used to mix drilling fluids for Well ER-7-1 came from the Radioactive Waste Management Site fill stand (a mix of waters Water Well 4and Water Well 4A) and Water Well 5B.

2. A concentrated solution of lithium bromide was added to all introduced fluids to make up a final concentration of 0.7 to 173 milligrams per liter.

Table A-3-2

Well ER-7-1 Cement Composition

\begin{tabular}{|c|c|c|c|}
\hline $\begin{array}{c}\text { Cement } \\
\text { Composition }\end{array}$ & $\begin{array}{c}\text { 20-inch } \\
\text { Conductor Casing }\end{array}$ & $\begin{array}{c}\text { 13d -inch } \\
\text { Surface Casing }\end{array}$ & Completion \\
\hline \hline Redi-Mix & $\begin{array}{l}0 \text { to } 36.6 \mathrm{~m}^{\mathrm{a}} \\
(0 \text { to } 120 \mathrm{ft})\end{array}$ & Not used & Not used \\
\hline Type II neat & Not used & $\begin{array}{c}520.6 \text { to } 534.9 \mathrm{~m} \\
\left(1,708^{\mathrm{C}} \text { to } 1,755 \mathrm{ft}\right)\end{array}$ & Not used \\
\hline \hline
\end{tabular}

a meter(s)

b foot (feet)

c estimated 
This page intentionally left blank.

A-3-2 


\section{Appendix B \\ Well ER-7-1 Fluid Management Data}




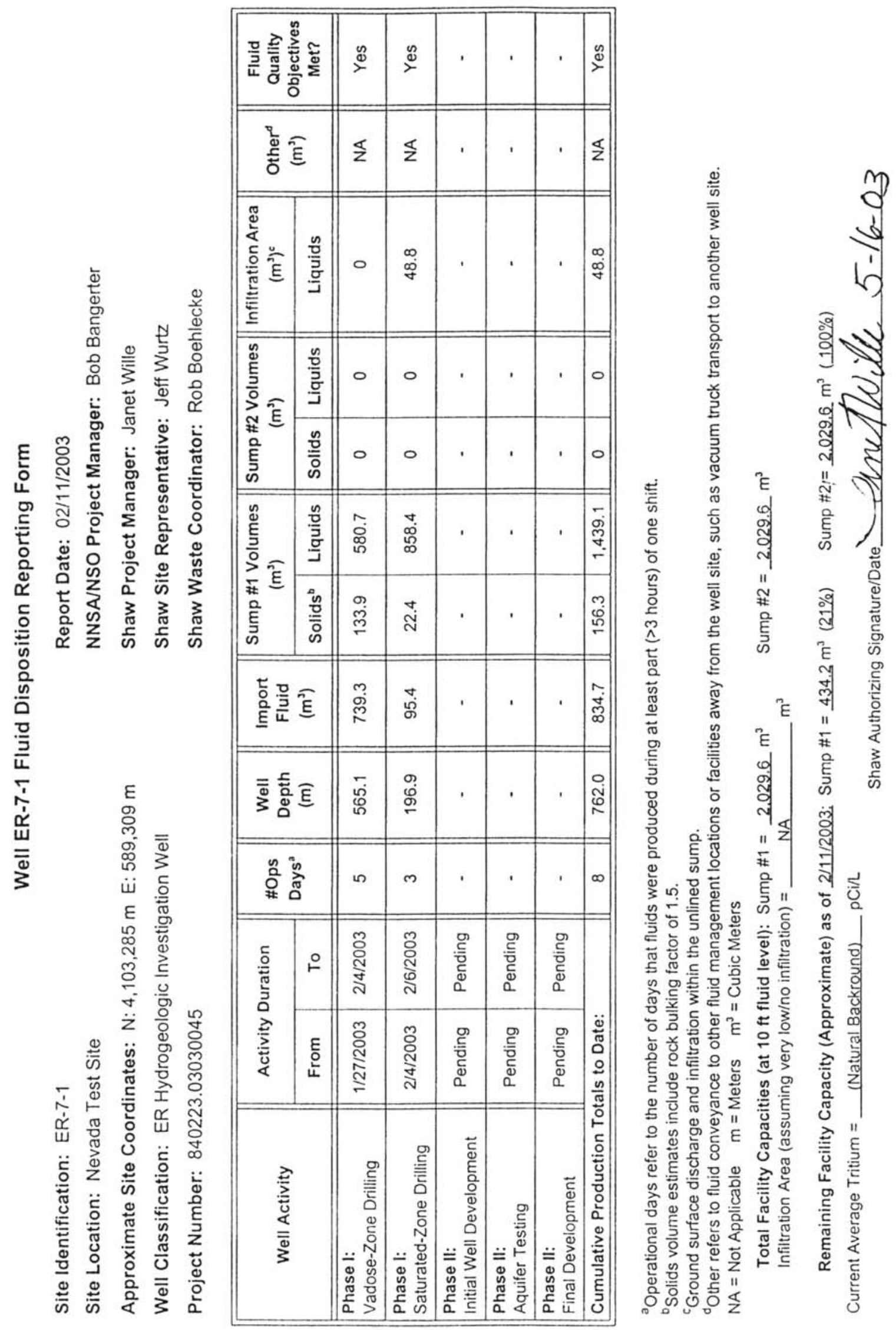

B-1 
Preliminary Analytical Results for Groundwater Characterization Sample from Well ER-7-1

\begin{tabular}{|c|c|c|c|c|c|c|c|c|c|c|c|c|c|c|}
\hline \multirow{2}{*}{ Sample Number } & \multirow{2}{*}{$\begin{array}{l}\text { Date } \\
\text { Collected }\end{array}$} & \multirow{2}{*}{ Comment } & & \multicolumn{8}{|c|}{ Resource Conservation Recovery Act Metals (mg/L) ${ }^{a}$} & \multirow{2}{*}{$\begin{array}{l}\text { Gross } \\
\text { Alpha } \\
\text { (pCi/L) }^{\mathrm{b}}\end{array}$} & \multirow{2}{*}{$\begin{array}{l}\text { Gross } \\
\text { Beta } \\
\text { (pCi/L) }\end{array}$} & \multirow{2}{*}{$\begin{array}{l}\text { Tritium } \\
(\mathrm{pCi} / L \mathbf{L})\end{array}$} \\
\hline & & & & Arsenic & Barium & Cadmium & Chromium & Lead & Selenium & Silver & Mercury & & & \\
\hline \multirow[b]{2}{*}{ ER-7-1-020903-1 } & \multirow[b]{2}{*}{ 02/09/2003 } & \multirow{2}{*}{$\begin{array}{l}\text { Groundwater } \\
\text { Characterization } \\
\text { Sample }\end{array}$} & Total & $0.0031(B)^{\mathrm{C}}$ & 0.12 & $0.005(U)^{d}$ & 0.0017 (B) & $0.003(U)$ & $0.005(U)$ & $0.01(U)$ & 0.000025 (B) & & & \\
\hline & & & Dissolved & 0.0032 (B) & $0.069(\mathrm{~B})$ & $0.005(U)$ & 0.00059 (B) & $0.003(U)$ & $0.005(U)$ & $0.01(U)$ & 0.000019 (B) & $\begin{array}{c}4.8(L T)^{e} \\
E^{f}=2\end{array}$ & $\begin{array}{c}9.7 \\
E=2\end{array}$ & $\begin{array}{c}0 \\
E=230\end{array}$ \\
\hline \multicolumn{4}{|c|}{ Contract-Required Detection Limit } & 0.01 & 0.1 & 0.005 & 0.01 & 0.003 & 0.005 & 0.01 & 0.0002 & $N / A^{g}$ & N/A & N/A \\
\hline \multicolumn{4}{|c|}{ Nevada Drinking Water Standard (NDWS) } & 0.05 & 2.0 & 0.005 & 0.1 & 0.015 & 0.05 & 0.1 & 0.002 & 15 & 50 & 20,000 \\
\hline \multicolumn{4}{|c|}{5 Times NDWS } & 0.25 & 10 & 0.025 & 0.5 & 0.075 & 0.25 & 0.5 & 0.01 & 75 & 250 & 100,000 \\
\hline
\end{tabular}

Data provided by Shaw (Shaw, 2003).

All analyses for metals by Paragon Analytics, Inc. Analyses for radionuclides by Bechtel Nevada (filtered prior to analysis).

a $\quad \mathrm{mg} / \mathrm{L}=$ milligrams per liter

b $\quad \mathrm{pCi} / \mathrm{L}=$ picocuries per liter

c $\quad B=$ Result less than Contract-Required Detection Limit, but greater than the Instrument Detection Limit

d $\quad U=$ Result less the Instrument Detection Limit or the Minimum Detectable Concentration (MDC)

e $\quad$ LT $=$ Result less than the requested MDC but greater than sample specific MDC

f $\quad E=$ Error

g $\quad \mathrm{N} / \mathrm{A}=$ Not applicable 


\section{Appendix C \\ Detailed Lithologic Log for Well ER-7-1}


Detailed Lithologic Log for Well ER-7-1

Logged by Heather Huckins-Gang, Bechtel Nevada

September 2003

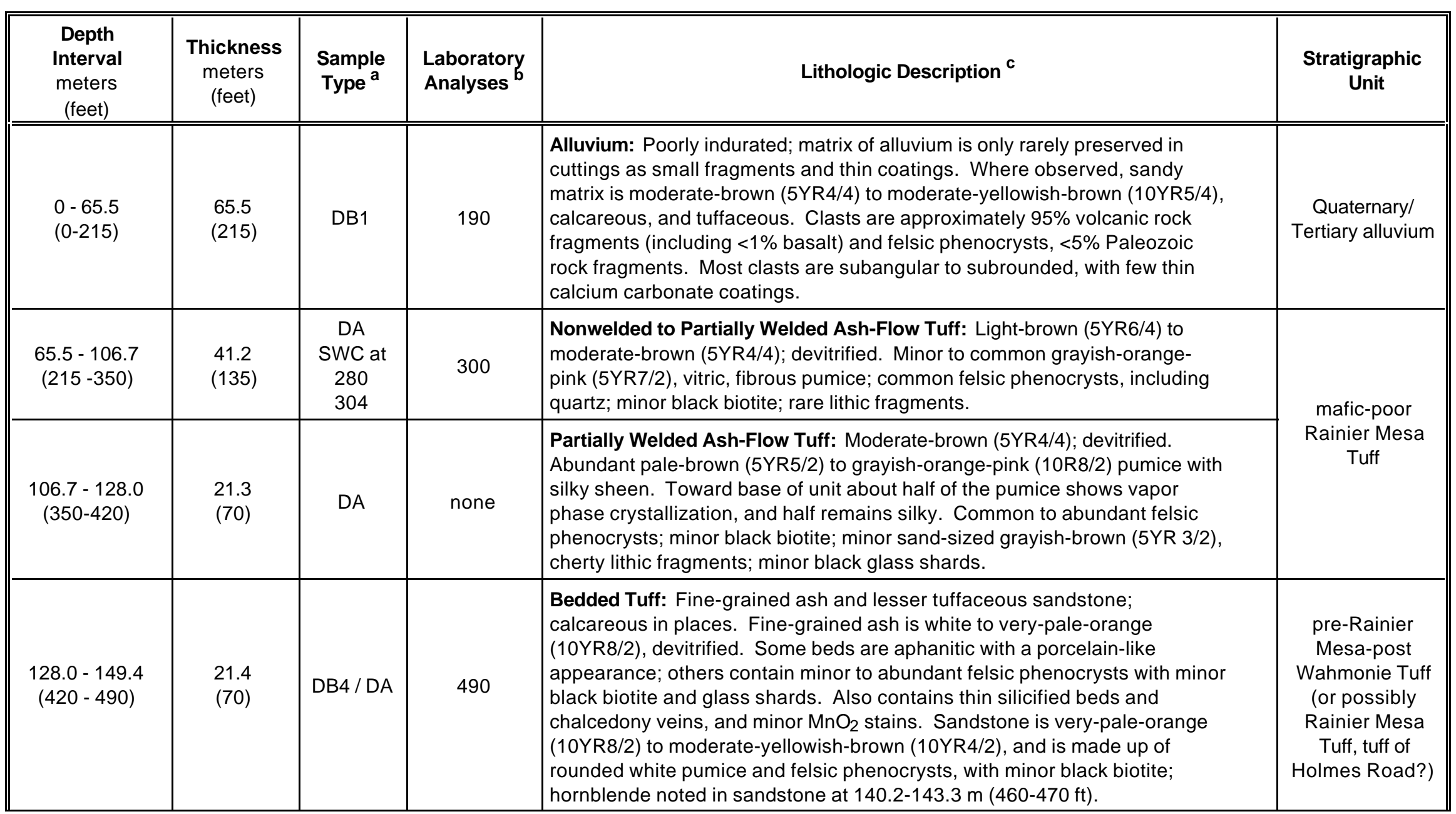




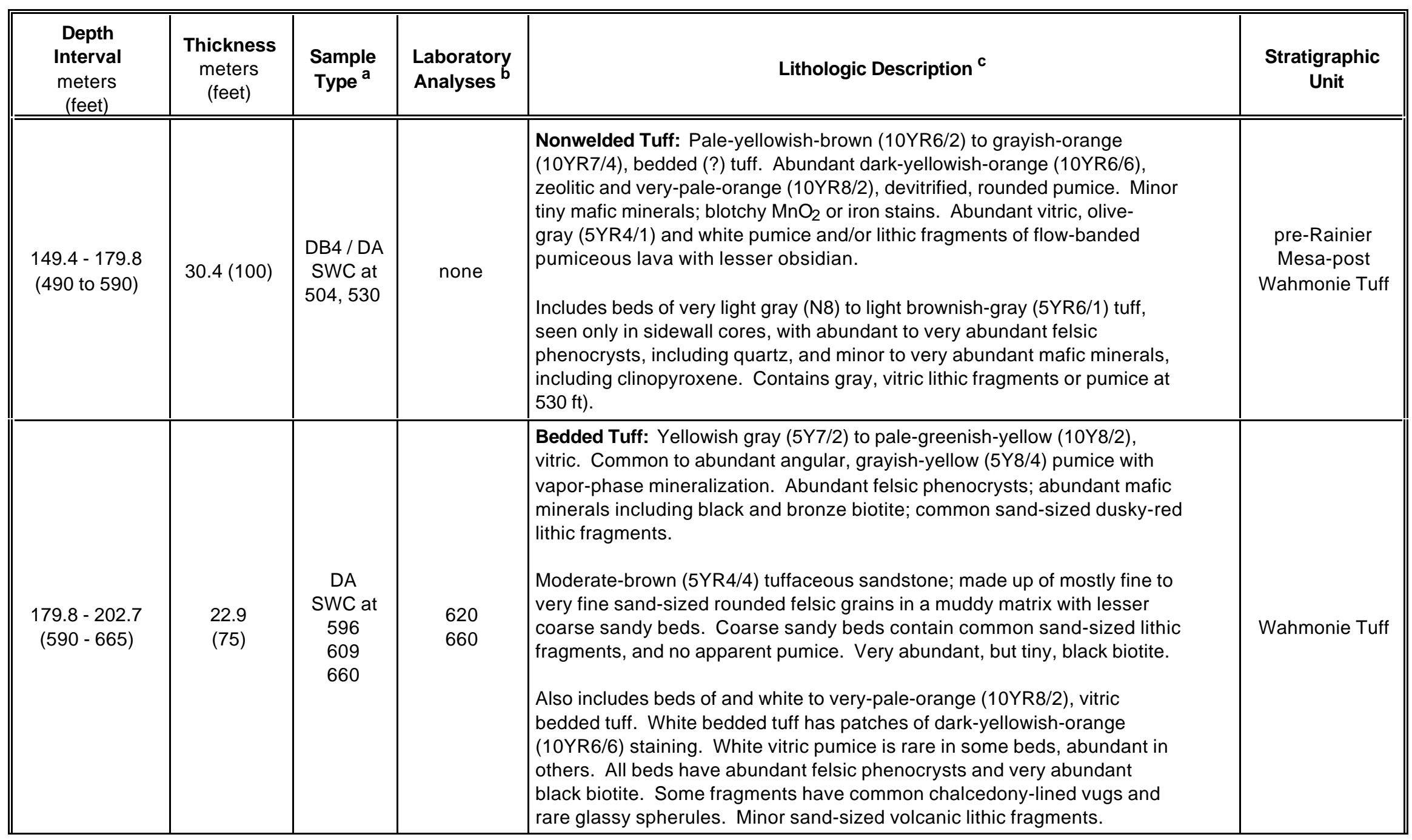




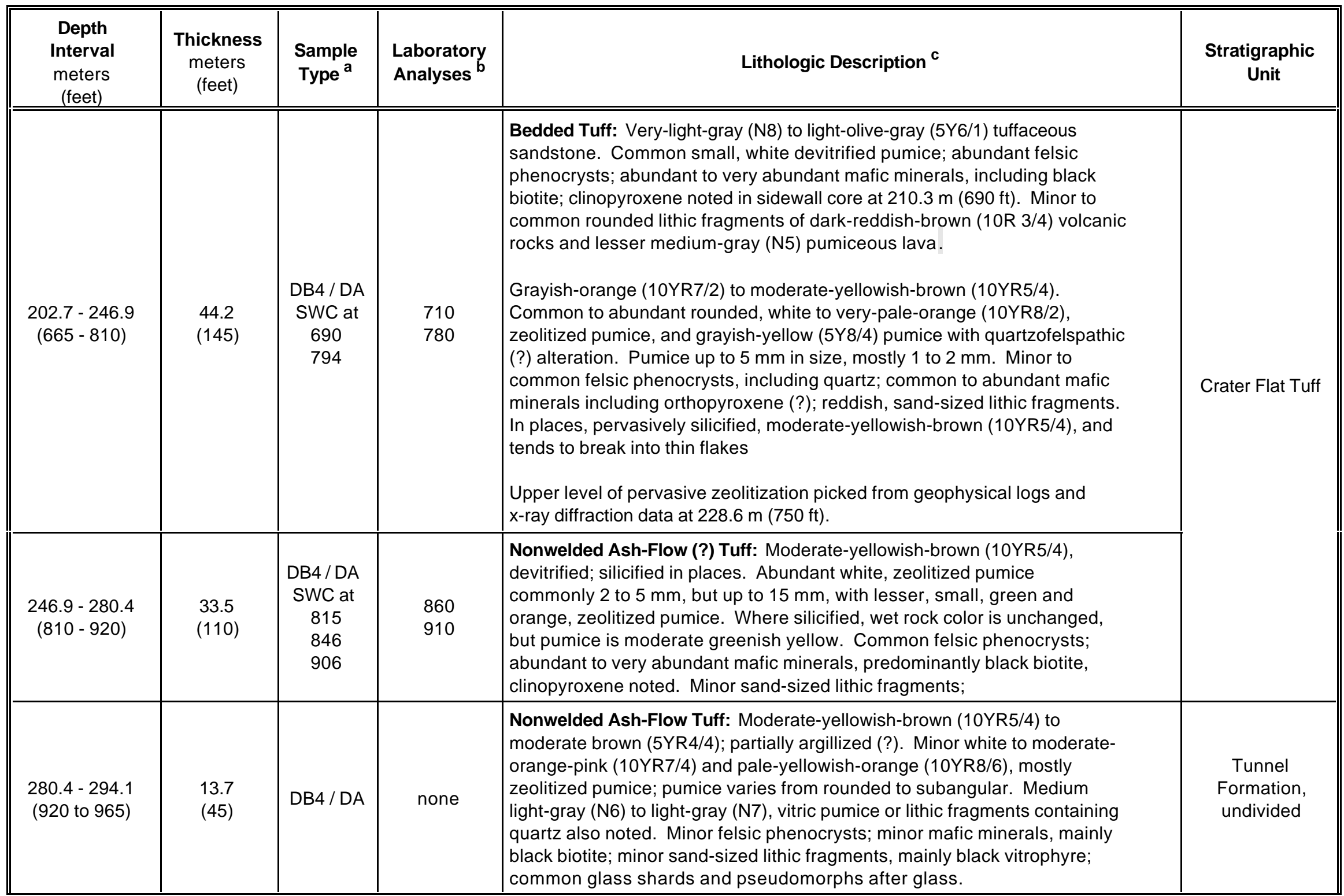




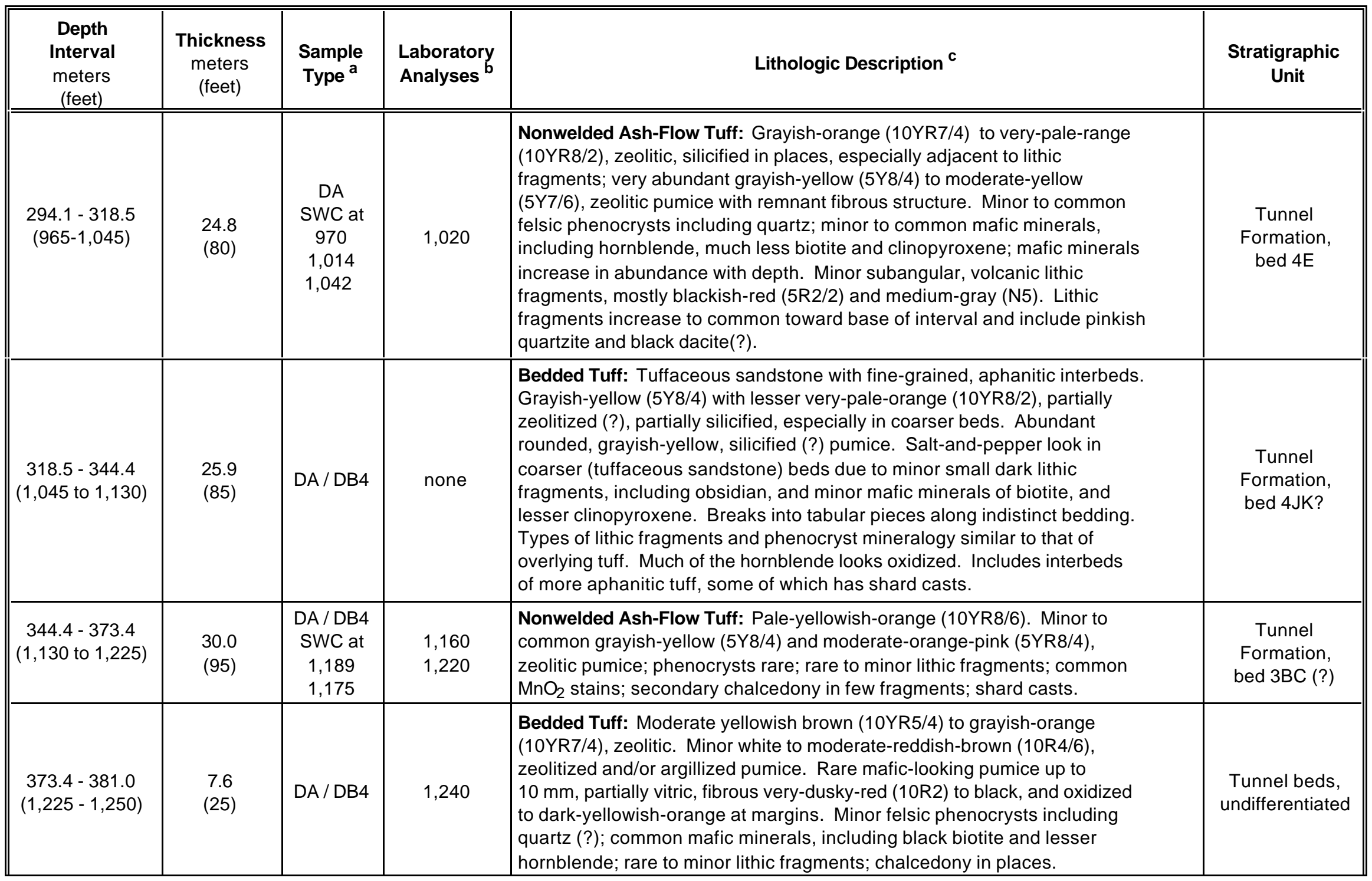




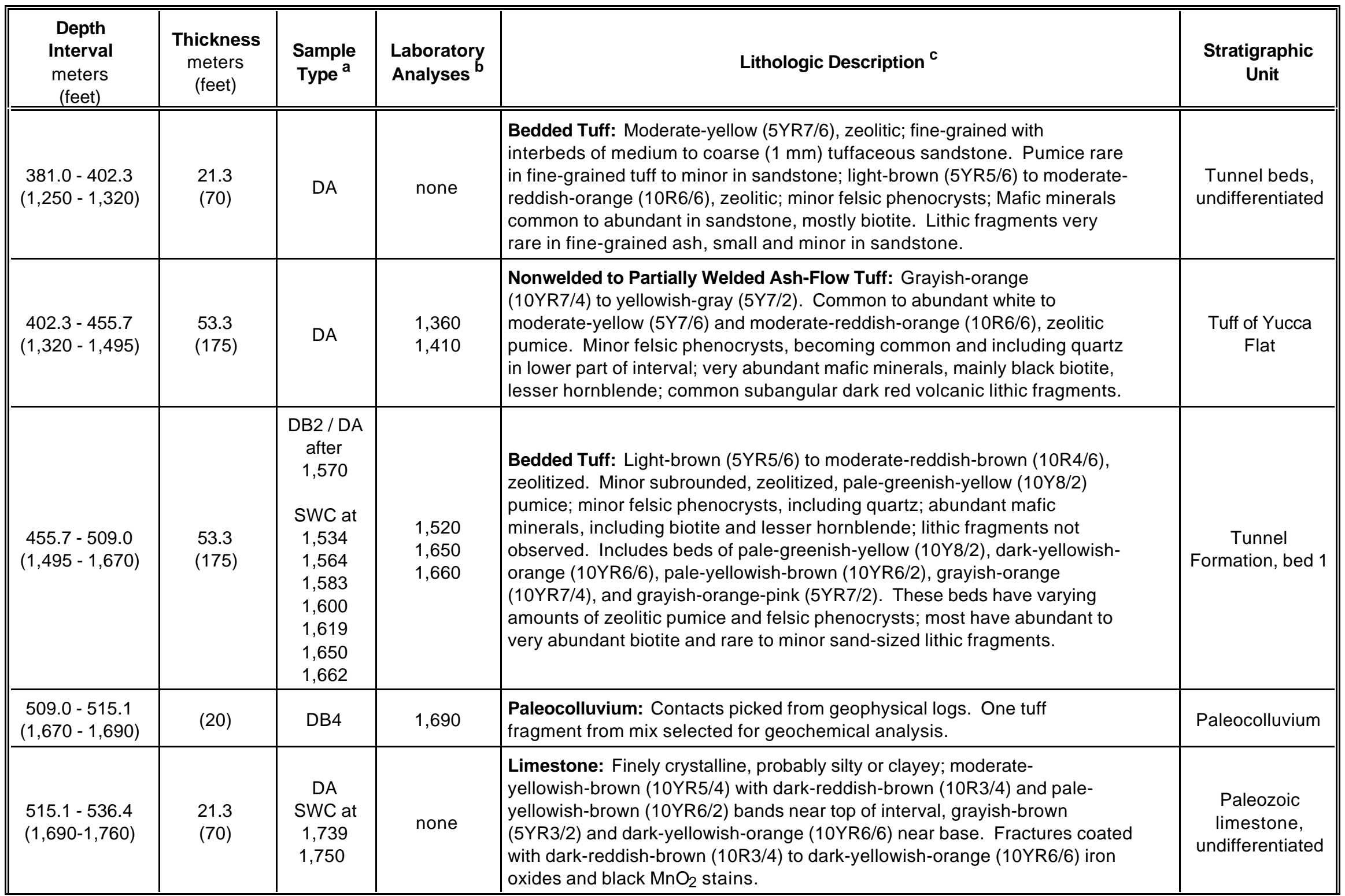




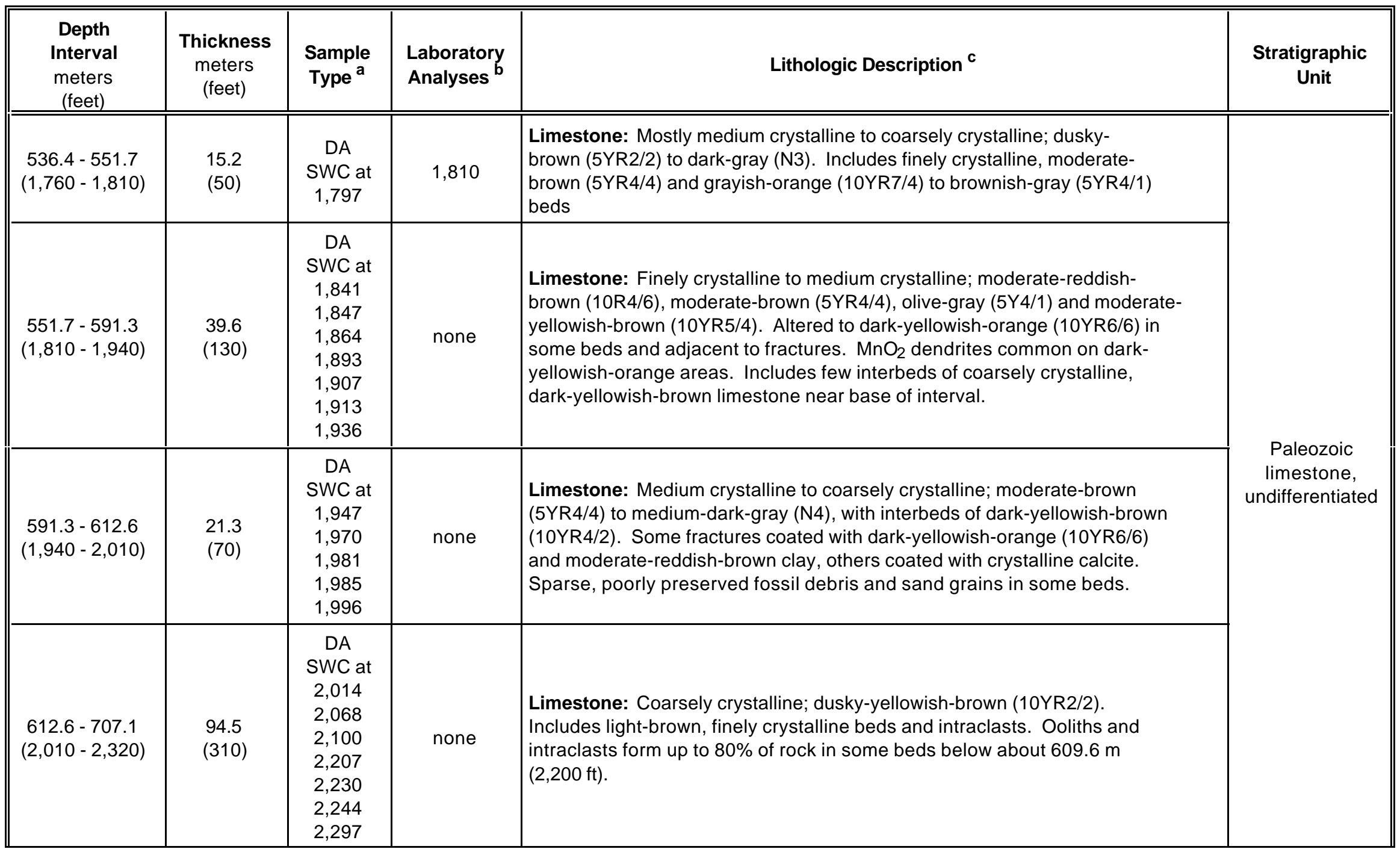




\begin{tabular}{|c|c|c|c|c|c|}
\hline $\begin{array}{c}\text { Depth } \\
\text { Interval } \\
\text { meters } \\
\text { (feet) } \\
\end{array}$ & $\begin{array}{c}\text { Thickness } \\
\text { meters } \\
\text { (feet) }\end{array}$ & $\begin{array}{l}\text { Sample } \\
\text { Type }^{a}\end{array}$ & $\begin{array}{l}\text { Laboratory } \\
\text { Analyses }\end{array}$ & Lithologic Description $^{c}$ & $\begin{array}{c}\text { Stratigraphic } \\
\text { Unit }\end{array}$ \\
\hline
\end{tabular}

a $\quad \mathbf{D A}=$ drill cuttings that represent lithologic character of interval; $\mathbf{D B} 1=$ drill cuttings enriched in hard components; $\mathbf{D B} 2=$ cuttings from interval different than that drilled; DB4 = cuttings that are intimate mixtures of units; $\mathbf{S W C}=$ sidewall core. Sample depths in feet. See Table 3-1 of this report for more information on sidewall core samples.

b Analyses completed to date: $x$-ray diffraction, $x$-ray fluoresence, wet chemical analysis for iron. See Table 3-2 of this report for additional information.

c Descriptions are based mainly on visual examination of lithologic samples using a 10x- to 40x-zoom binocular microscope, and incorporating observations from geophysical logs and results of laboratory analyses. Colors describe wet sample color.

Abundances for felsic phenocrysts, pumice fragments, and lithic fragments: trace $=$ only one or two individuals observed; rare $=\leq 1 \%$;

minor $=5 \%$; common $=10 \%$; abundant $=15 \%$; very abundant $\geq 20 \%$.

Abundances for mafic minerals: trace $=$ only one or two individuals observed; rare $=\leq 0.05 \%$; minor $=0.2 \%$; common $=0.5 \%$;

abundant $=1 \%$; very abundant $=\geq 2 \%$. 
This page intentionally left blank.

C-8 


\section{Appendix D \\ Geophysical Logs Run in Well ER-7-1}


Appendix D contains unprocessed data presentations of selected geophysical logs run in Well ER-7-1.

Table D-1 summarizes the logs presented. See Table 3-3 for more information.

Table D-1

Well ER-7-1 Geophysical Logs Presented

\begin{tabular}{|c|c|c|c|c|}
\hline Log Type & $\begin{array}{c}\text { Run } \\
\text { Number }\end{array}$ & Date & meters $^{\text {Log }}$ & feet \\
\hline Caliper & $\begin{array}{l}\text { CA6-1 } \\
\text { CA6-2 }\end{array}$ & $\begin{array}{l}01 / 30 / 2003 \\
02 / 07 / 2003\end{array}$ & $\begin{array}{r}15.2-536.5 \\
487.7-756.5\end{array}$ & $\begin{array}{c}50-1,760 \\
1,600-2,482\end{array}$ \\
\hline Epithermal Neutron & $\begin{array}{l}\text { DSEN-1 } \\
\text { DSEN-2 }\end{array}$ & $\begin{array}{l}01 / 31 / 2003 \\
02 / 07 / 2003\end{array}$ & $\begin{array}{r}15.2-538.9 \\
518.2-759.3\end{array}$ & $\begin{array}{c}50-1,768 \\
1,700-2,491\end{array}$ \\
\hline Density & $\begin{array}{l}\text { SDL-1 } \\
\text { SDL-2 }\end{array}$ & $\begin{array}{l}01 / 31 / 2003 \\
02 / 07 / 2003\end{array}$ & $\begin{array}{c}13.7-538.9 \\
518.2-759.3\end{array}$ & $\begin{array}{c}45-1,768 \\
1,700-2,491\end{array}$ \\
\hline High Resolution Induction & HR1-1 & $01 / 31 / 2003$ & $36.6-537.4$ & $120-1,763$ \\
\hline Induction (resistivity) & DLL-1 & 02/07/2003 & $519.7-755.3$ & $1,705-2,478$ \\
\hline Gamma Ray & $\begin{array}{l}\text { GR-2 } \\
\text { GR-5 }\end{array}$ & $\begin{array}{l}01 / 31 / 2003 \\
02 / 07 / 2003\end{array}$ & $\begin{array}{r}15.2-536.5 \\
487.7-756.5\end{array}$ & $\begin{array}{c}50-1,760 \\
1,600-2,482\end{array}$ \\
\hline $\begin{array}{c}\text { Spectral Gamma Ray } \\
\text { (potassium, thorium, uranium) }\end{array}$ & $\begin{array}{l}\text { SGR-1 } \\
\text { SGR-2 }\end{array}$ & $\begin{array}{l}01 / 31 / 2003 \\
02 / 07 / 2003\end{array}$ & $\begin{array}{r}26.2-527.0 \\
579.4-746.8 \\
\end{array}$ & $\begin{array}{c}86-1,729 \\
1,704-2,450 \\
\end{array}$ \\
\hline Spontaneous Potential & SP-1 & $02 / 07 / 2003$ & $519.7-755.3$ & $1,705-2,478$ \\
\hline $\begin{array}{c}\text { Digital Array Sonic } \\
\text { (delta T and sonic porosity) }\end{array}$ & FWS-1 & 02/07/03 & $518.2-756.2$ & $1,700-2,481$ \\
\hline $\begin{array}{c}\text { Chemistry } \\
\text { (temperature, } \mathrm{pH}, \\
\text { electrical conductivity) }\end{array}$ & 1 & 02/08/03 & $565.1-761.4$ & $1,854-2,498$ \\
\hline
\end{tabular}




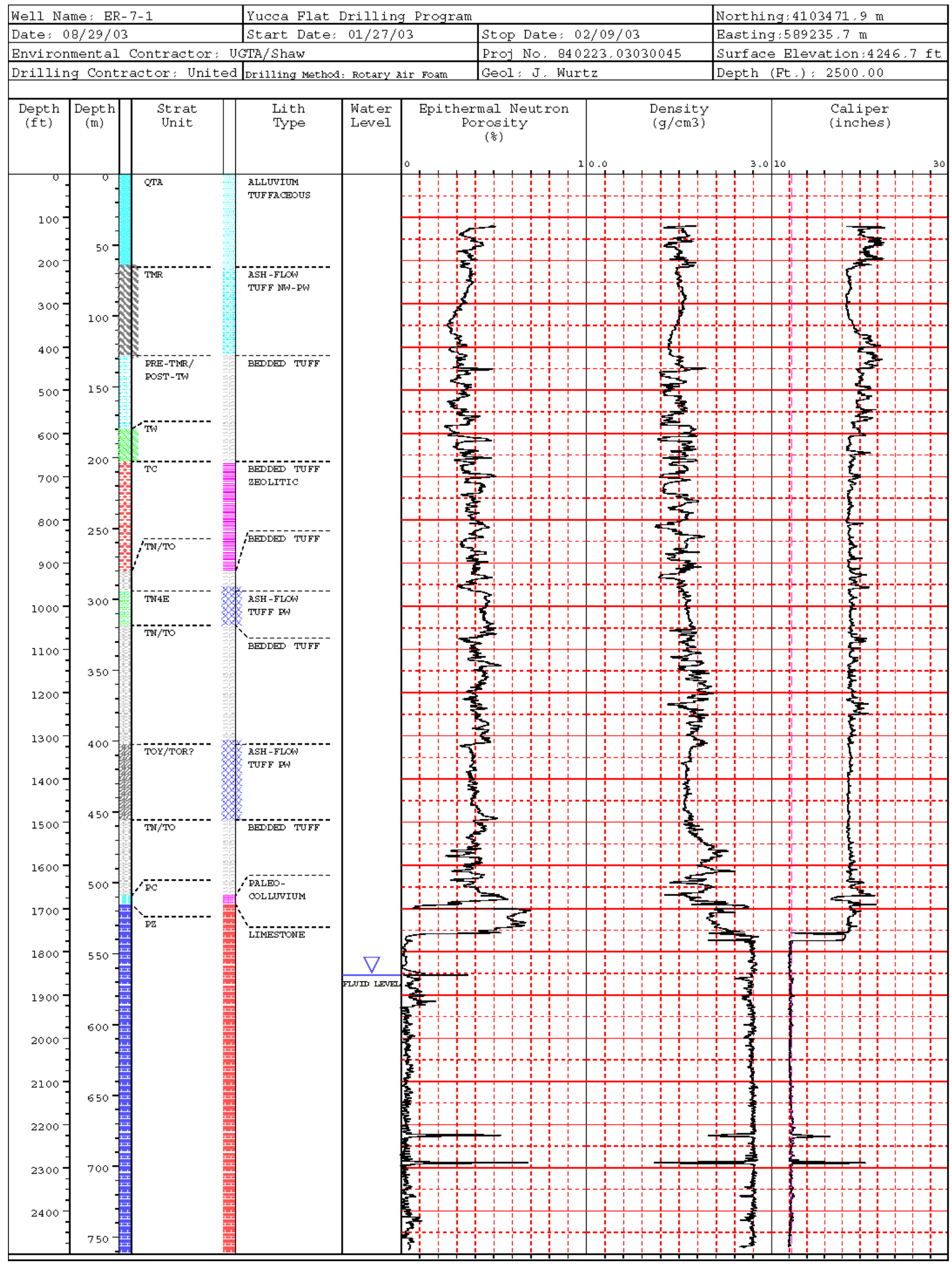




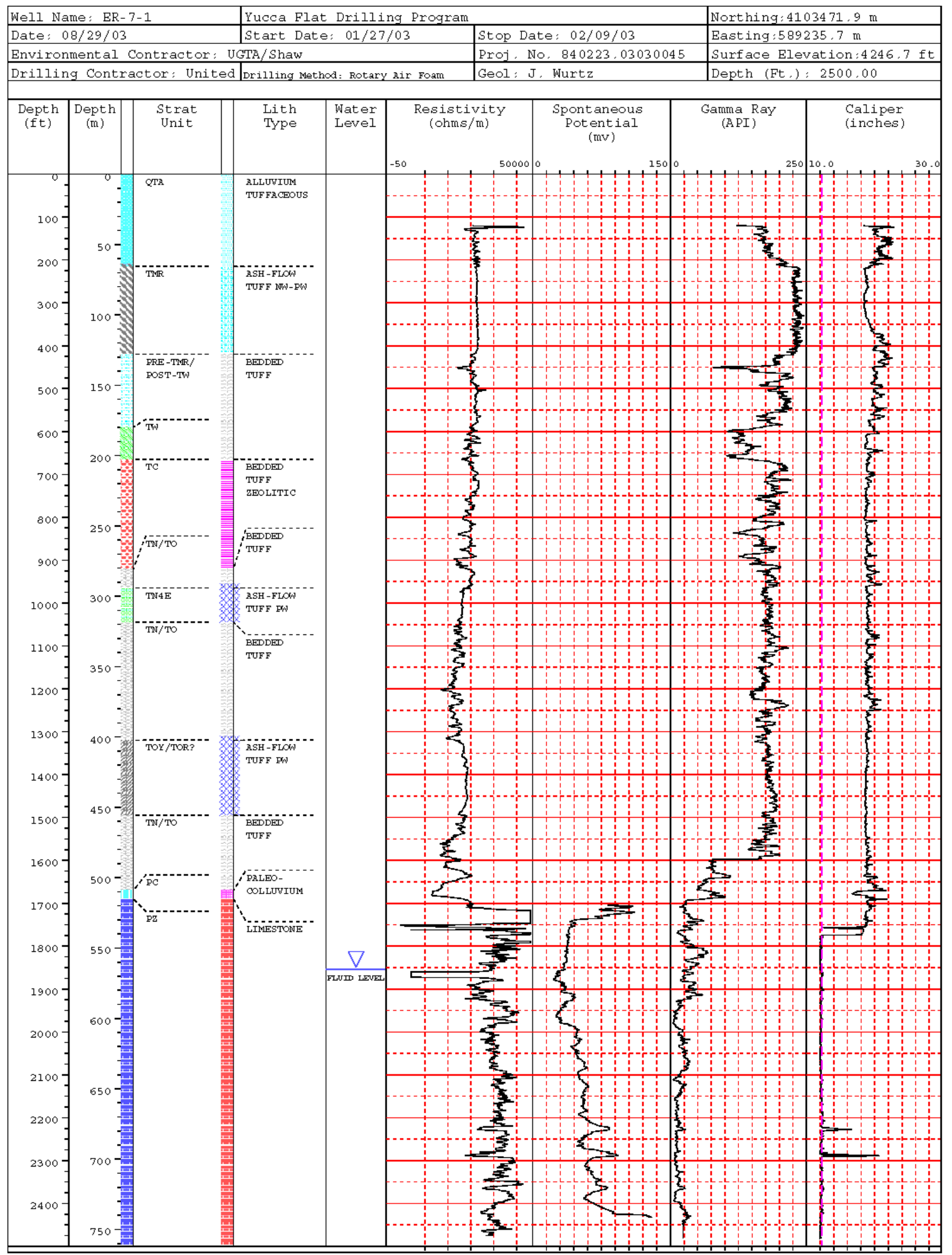




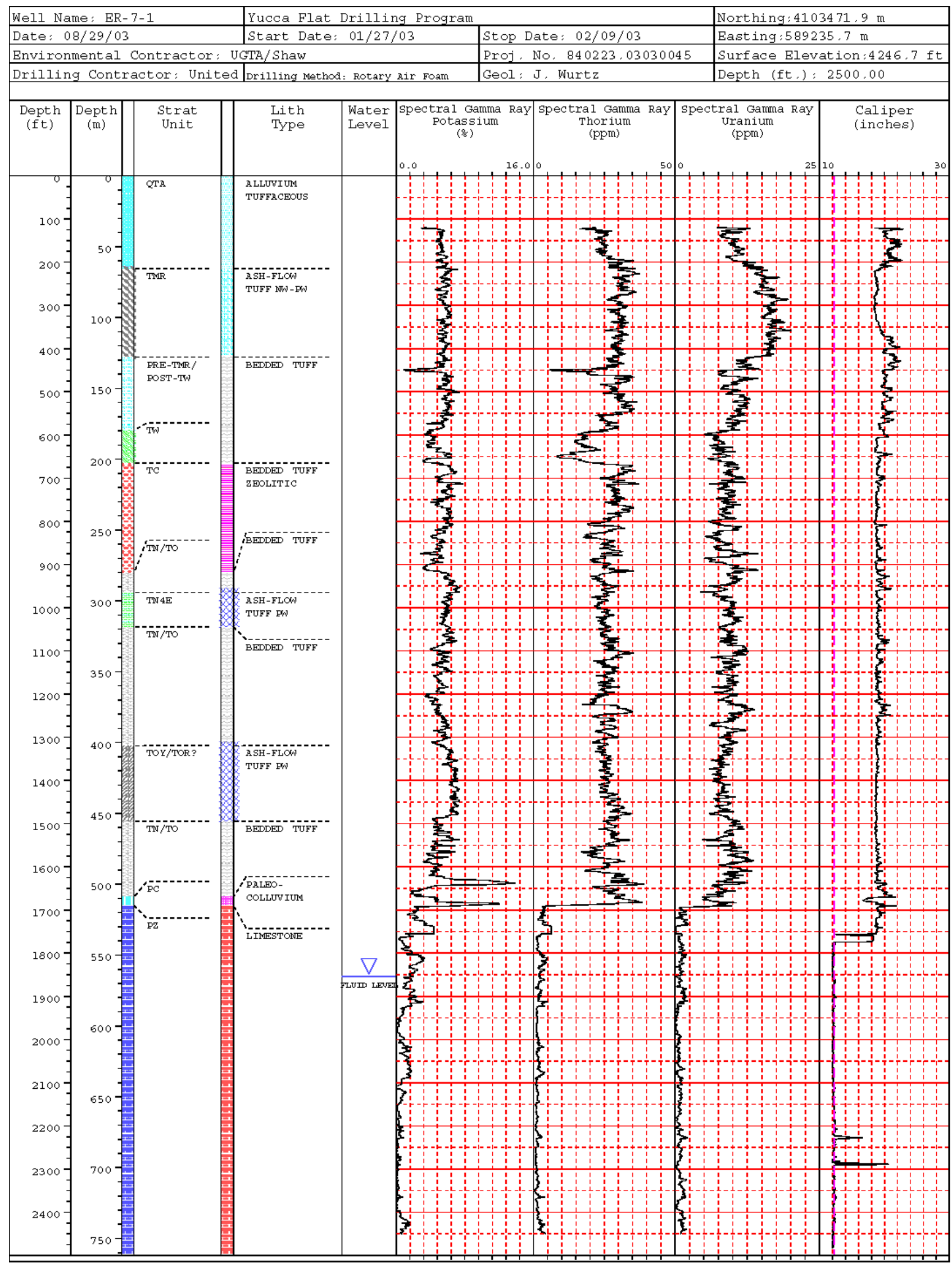




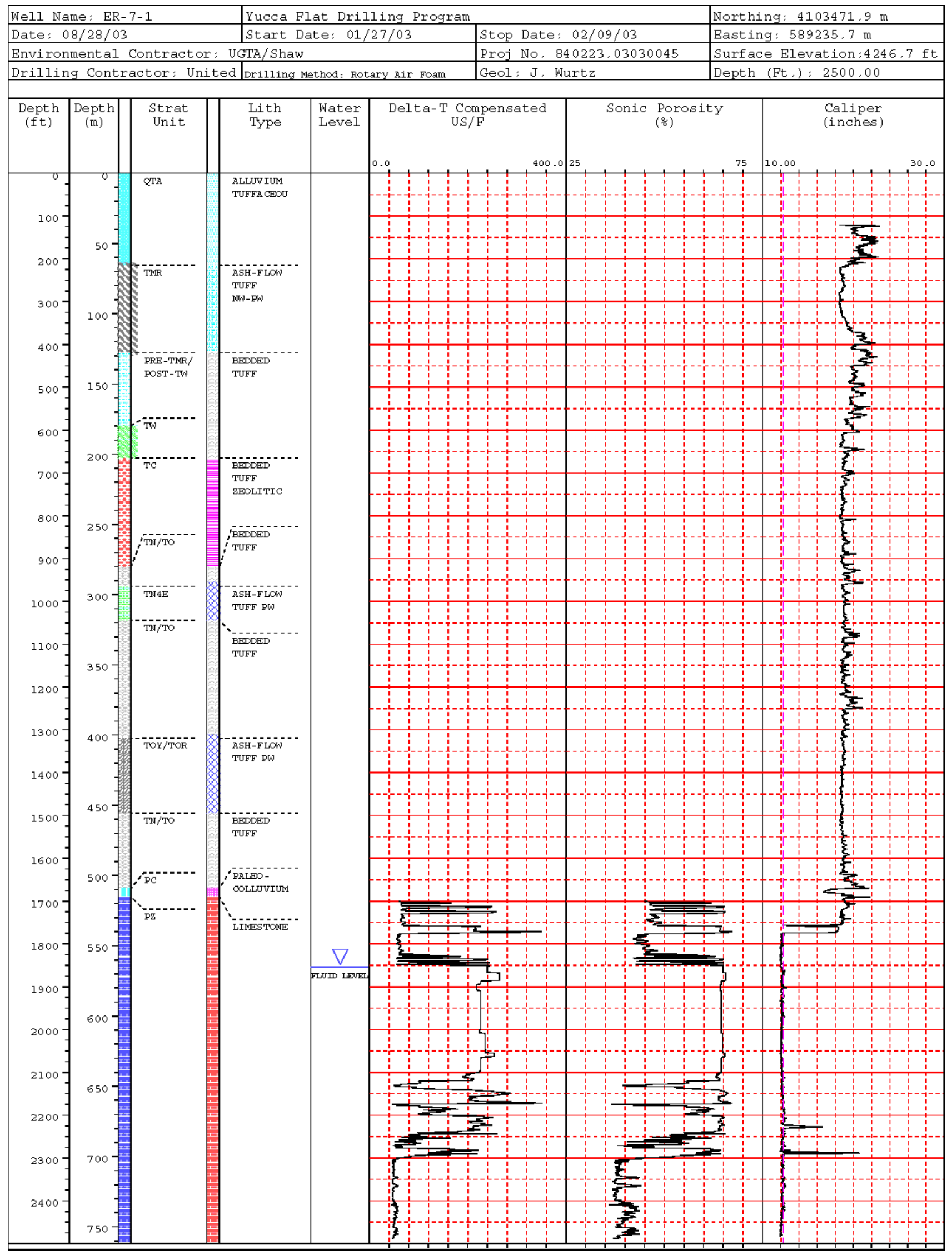




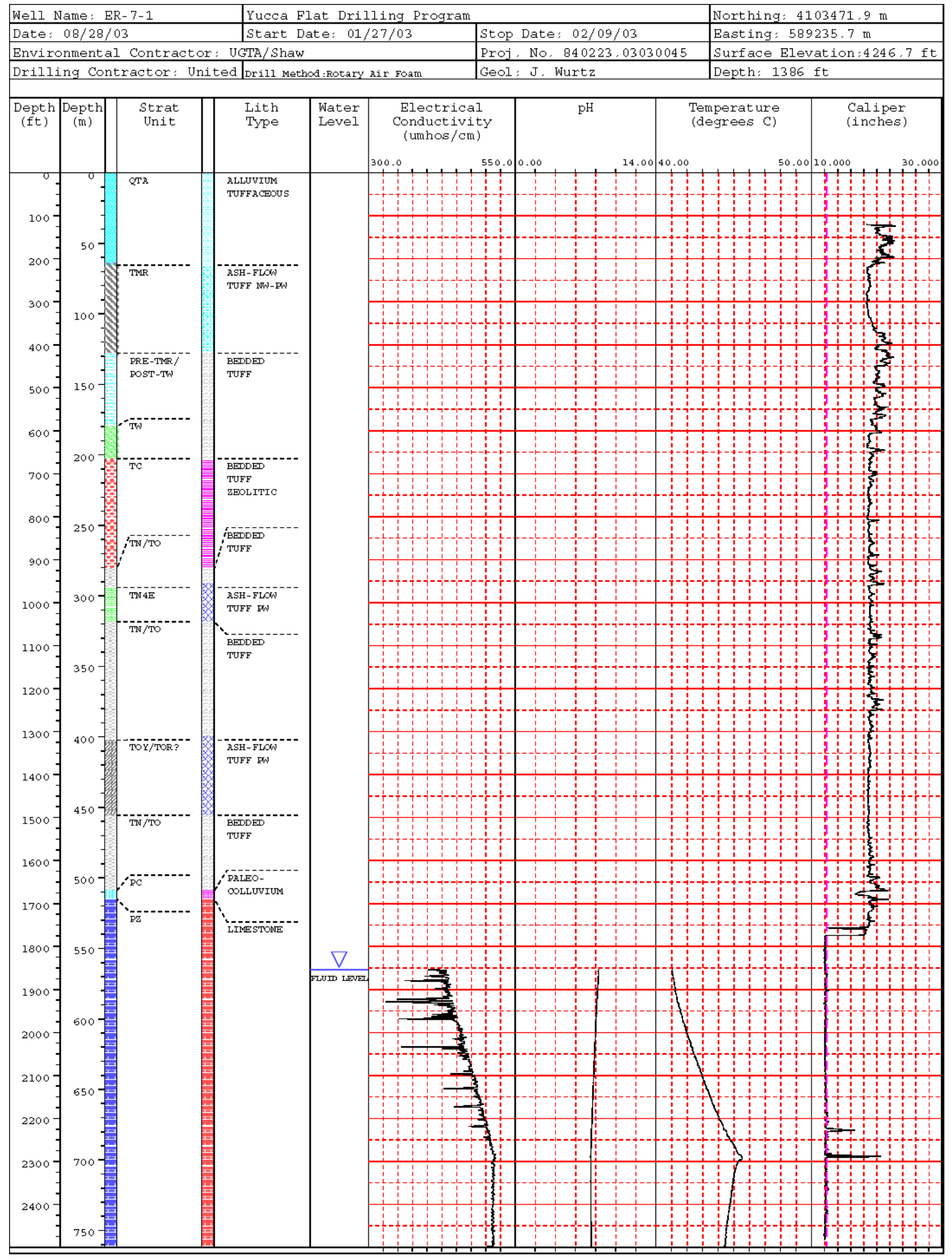




\section{Distribution List}

\section{$\underline{\text { Copies }}$}

R. M. Bangerter

U.S. Department of Energy

National Nuclear Security Administration

Nevada Site Office

Environmental Restoration Division

P.O. Box 98518, M/S 505

Las Vegas, NV 89193-8518

U.S. Department of Energy

National Nuclear Security Administration

Nevada Site Office

Technical Library

P.O. Box 98518, M/S 505

Las Vegas, NV 89193-8518

U.S. Department of Energy

National Nuclear Security Administration

Nevada Site Office

Nuclear Testing Archive

Public Reading Facility

P.O. Box 98518, M/S 400

Las Vegas, NV 89193-8518

U.S. Department of Energy

1 (electronic)

Office of Scientific and Technical Information

Post Office Box 62

Oak Ridge, Tennessee 37831-0062

K. A. Hoar, Director

U.S. Department of Energy

National Nuclear Security Administration

Nevada Site Office

Environment, Safety and Health Division

P.O. Box 98518, M/S 505

Las Vegas, NV 89193-8518

P. K. Ortego

Bechtel Nevada

P.O. Box 98521, MS NLV082

Las Vegas, NV 89193-8521 


\section{Distribution List (continued)}

\section{$\underline{\text { Copies }}$}

John McCord

UGTA Project Manger

Stoller Navarro

7710 W. Cheyenne

Building 3

Las Vegas, NV 89129

Stoller Navarro Library

Stoller Navarro

7710 W. Cheyenne

Building 3

Las Vegas, NV 89129

W. L. Hawkins

Los Alamos National Laboratory

P. O. Box 1663

Los Alamos, NM 87545-1663

G. A. Pawloski

Lawrence Livermore National Laboratory

P. O. Box 808

Livermore, CA 94551-0808

T. P. Rose

Lawrence Livermore National Laboratory

P. O. Box 808

Livermore, CA 94551-0808

B. K. Thompson

DOE/USGS Cooperative Program Manager

U.S. Geological Survey

Water Resources Division

6770 South Paradise Road

Las Vegas, NV 89119-3721

C. E. Russell

Desert Research Institute

755 East Flamingo Road

P.O. Box 19040

Las Vegas, NV 89119-7363 